\title{
A detailed sequential extraction study of selenium in coal and coal-associated strata from a coal mine in West Virginia
}

Mimi Roy

West Virginia University

Follow this and additional works at: https://researchrepository.wvu.edu/etd

\section{Recommended Citation}

Roy, Mimi, "A detailed sequential extraction study of selenium in coal and coal-associated strata from a coal mine in West Virginia" (2005). Graduate Theses, Dissertations, and Problem Reports. 2307. https://researchrepository.wvu.edu/etd/2307

This Thesis is protected by copyright and/or related rights. It has been brought to you by the The Research Repository @ WVU with permission from the rights-holder(s). You are free to use this Thesis in any way that is permitted by the copyright and related rights legislation that applies to your use. For other uses you must obtain permission from the rights-holder(s) directly, unless additional rights are indicated by a Creative Commons license in the record and/ or on the work itself. This Thesis has been accepted for inclusion in WVU Graduate Theses, Dissertations, and Problem Reports collection by an authorized administrator of The Research Repository @ WVU. For more information, please contact researchrepository@mail.wvu.edu. 


\title{
A Detailed Sequential Extraction Study of Selenium in Coal and Coal-Associated Strata from a Coal Mine in West Virginia
}

\author{
Mimi Roy
}

\author{
Thesis submitted to the \\ Eberly College of Arts and Sciences \\ at West Virginia University \\ in partial fulfillment of the requirements \\ for the degree of \\ Master of Science \\ in \\ Geology \\ Dorothy J. Vesper, Ph.D., Chair \\ Joseph J. Donovan, Ph.D. \\ Jeffrey Skousen, Ph.D. \\ William Grady \\ Department of Geology and Geography
}
Morgantown, West Virginia
2005

Keywords: Selenium, coal, non-coal units, sequential extraction 


\title{
ABSTRACT \\ A Detailed Sequential Extraction Study of Selenium in Coal and Coal-Associated Strata from a Coal Mine in West Virginia
}

\begin{abstract}
Mimi Roy
This study of the mode of occurrence and distribution of selenium in a rock core from southcentral West Virginia reveals that total selenium concentration varies by rock type. Rocks with total selenium $>1 \mathrm{mg} / \mathrm{kg}$ were of circum-neutral $\mathrm{pH}$ based on acid base accounting data. No direct correlation was found between selenium concentration in the rocks and that of sulfur and/or total organic carbon. The distribution of total selenium was also controlled by stratigraphy. The amount of total selenium extracted from various rock types like coal, shale, sandstone, mudstone and "carbolith" materials ranged from $<1 \%$ to $>50 \%$. Selenium extracted from coal was mostly from the sulfide fraction. Selenium extracted from shales averages approximately $40 \%$ by mass, mainly in the organic fraction. More selenium was extracted from shales in coal-proximate zones averaging about $50 \%$ by mass. Extraction conditions are rarely encountered in natural geochemical settings and are thus likely an overestimate of field conditions.
\end{abstract}




\section{Acknowledgements}

I would like to thank those individuals who provided their assistance during the completion of this research. Without their support, the successful completion of this work would not have been possible.

Specifically I would like to thank all the committee members, Dr. Dorothy Vesper, Dr. Joseph Donovan, Dr. Jeffrey Skousen, and William Grady for their thoughtful input, cooperation, expertise and patience throughout the entire phase of this research. Dr. Vesper's ever encouraging guidance and always being cooperative in discussing the minute details and technical aspects helped me immensely in achieving this goal.

This project was supported by the West Virginia Water Research Institute and the USDI Office of Surface Mining as part of the Acid Drainage Technology Initiative, Cooperative Agreement CT4-43030

Last but not the least, thanks are due to Sriroop, and to my parents for extending moral support and always encouraging me. 
Abstract....................................................................... ii

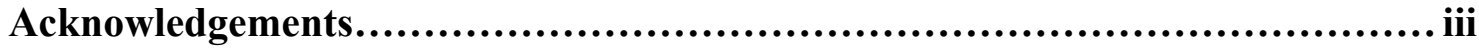

Table of Contents............................................................ iv

List of Tables.............................................................. vi

List of Figures............................................................. vii

List of Acronyms........................................................... ix

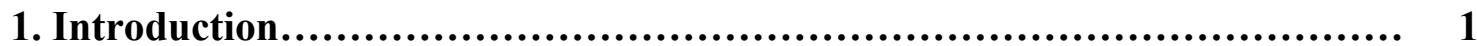

1.1 Statement of problem.................................................... 1

1.2 Purpose and objectives................................................... 2

2. Literature review................................................................ 3

2.1 Environmental geochemistry of selenium............................... 3

2.2 Distribution and prediction of total selenium in rocks.................... 5

2.2.1 Selenium sources and distribution by location and rock type........ 5

2.2.2 Total selenium in West Virginia rocks............................. 8

2.2.3 Relationship between total selenium concentration and other chemical parameters.......................................................... 13

2.3 Weathering of selenium containing rocks.............................. 16

3. Materials and Methods.................................................. 20

3.1 Nature and source of samples....................................... 20

3.2 Existing chemical data provided with samples......................... 22

3.3 Additional laboratory analysis of solid samples......................... 22

3.4 Sequential extraction procedure...................................... 24

3.5 Extraction solutions and residues...................................... 26

3.6 Calculations from raw data........................................... 27

3.7 Quality discussion of data............................................ 27

4. Results................................................................ 33

4.1 Total bulk selenium in rock samples................................. 33

4.1.1 Relationship between total selenium, stratigraphy and lithology.... 33

4.1.2 Relationship between total selenium and other parameters........... 37 
4.2 Sequential extraction data......................................................44

4.2.1 Distribution of data points.......................................... 44

4.2.2 Sum of extracted selenium data..................................... 44

4.2.3 Calculation of selenium extracted from different fractions........... 47

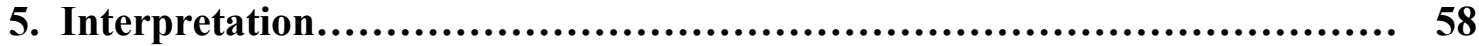

5.1 Predicting total selenium concentration from stratigraphy and lithology... 58

5.2 Predicting total selenium concentration in rock cores from other chemical parameters.......................................................... 59

5.3 Predicting relative extraction of selenium from different rock types......... 62

5.4 Mode of occurrence of selenium in different rock fractions................. 67

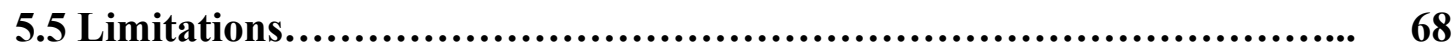

6. Conclusion............................................................... 72

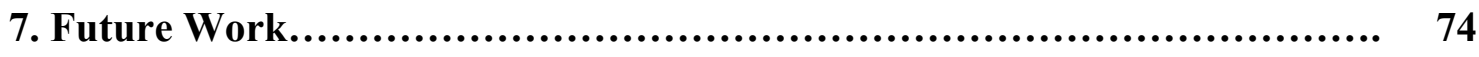

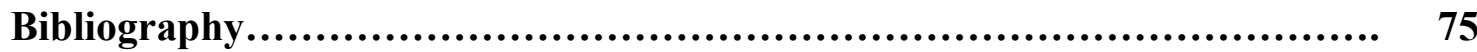

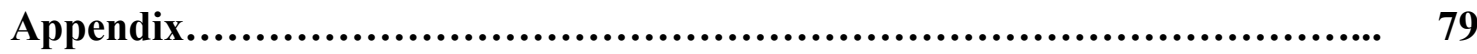

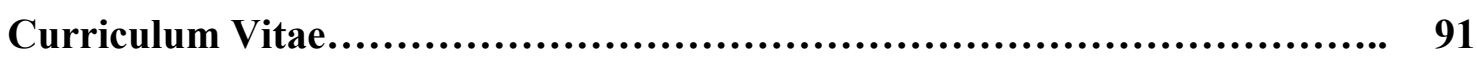




\section{LIST OF TABLES}

Table 2-1 Selenium concentration in major rock types based on 9000 samples collected from US coal regions and provinces

(Coleman et al., 1993)................................................ 6

Table 2-2 Average, maximum and minimum concentrations of selenium in US coal regions and provinces (Modified from Coleman et al., 1993)....

Table 2-3 Summary statistics of selenium in West Virginia coals

(WVGES, 2002a)............................................................... 10

Table 3-1 Sample description by rock type and available existing bulk data.... 21

Table 3-2 Sulfur fractionation data........................................ 23

Table 3-3 Sequential extraction procedure.................................... 25

Table 3-4 Quality of data based on sample contamination issues............... 30

Table 3-5 Estimated analytical error based on blind replicates................. 31

Table 4-1 Comparison of total selenium and sum of extracted selenium values.. 34

Table 4-2 Comparison of total selenium and sum of extracted selenium in different rock types............................................. 48

Table 5-1 Total sulfur, organic sulfur and selenium parameters for coal........ 63

Table A-1 Site and bulk analytical data for the rock core..................... 79

Table A-2 Compilation of total Se and extracted Se concentrations............ 82

Table A-3 Mean values and relative standard deviations of replicate samples in sequential extraction............................................ 84

Table A-4 Sequential extraction data for each individual fraction.............. 88

Table A-5 Comparison of arithmetic mean and geometric mean for the data... 90 


\section{LIST OF FIGURES}

Figure 2-1 pH-Eh diagram for selenium (Drever, 1998)......................... 4

Figure 2-2 Potentially toxic or acidic units associated with coal (Modified from Renton et al., 1989).....................................................

Figure 2-3 Stratigraphy and selenium content of coal beds in West Virginia

(WVGES, 2002a)..................................................

Figure 2-4 Geographic distribution of selenium in West Virginia coals

(WVGES, 2002a)

Figure 2-5 Distribution of selenium concentration in West Virginia (a) coals and (b) mudstones. Graphs generated using data from WVGES (2002b)

Figure 2-6 Distribution of selenium in various rock types from a mine in south western West Virginia (Modified from Mullennex, 2005)............. 15

Figure 2-7 Mode of selenium binding in rocks.................................... 19

Figure 3-1 Calculations for the data from sequential extraction................. 28

Figure 3-2 Separation of $S$ in different fractions of the extraction solutions

(F1 through F5)...................................................

Figure 4-1 Distribution of total selenium in different rock types. Values less

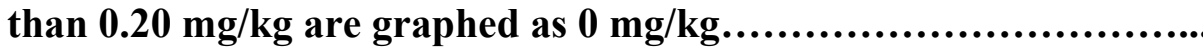

Figure 4-2 Distribution of total selenium with depth, formation and coal beds.

Non-detectable values $(<0.20 \mathrm{mg} / \mathrm{kg})$ are graphed as $0 \mathrm{mg} / \mathrm{kg} . \ldots \ldots \ldots 36$

Figure 4-3 Plot of total selenium values against paste pH. Samples with nondetectable selenium $(<0.20 \mathrm{mg} / \mathrm{kg})$ are graphed as $0 \mathrm{mg} / \mathrm{kg} . . . \ldots \ldots \ldots . .$.

Figure 4-4 Relationship between MPA and total selenium. (a) Plot of MPA against total selenium for all samples. Samples with non-detectable selenium $(<0.20 \mathrm{mg} / \mathrm{kg})$ are graphed as $0 \mathrm{mg} / \mathrm{kg}$. One data value value with MPA 84 tons/1000 tons not included in graph. (b) Plot of MPA against pyritic S...........................................

Figure 4-5 Plot of NNP against total selenium. Outliers with values of -96 tons 
/1000 tons and 82 tons/1000 tons are not included in graph............

Figure 4-6 Plot of TOC against total selenium. (a) For all rock types (b) For

shale. (c) For coal............................................... 42

Figure 4-7 Plot of $S$ against total selenium................................... 43

Figure 4-8 Comparison of total selenium measured in the bulk sample with the sum of the total selenium from the extraction steps and the residual fraction. The line has a slope of 1 ................................ 45

Figure 4-9 Comparative analysis of extracted selenium from different rocks... 46

Figure 4-10 Percentage of selenium extracted vs. total selenium (a) in shale and (b) in coal.

Figure 4-11 Extracted selenium by rock type. Depths (a) 0-40 ft, (b) 40-80 ft, (c) 80-120 ft, (d) 120-160 ft, (e) 160-200 ft, (f) 200-240 ft (g) 240-280 ft. (Note that scale of $x$-axis varies by figure to maximize the size of of the bar charts and aid interpretation.

Figure 5-1 Comparison of selenium concentrations from all rocks situated less than $2 \mathrm{ft}$ from coal horizons with that of rocks situated more than $2 \mathrm{ft}$ from coal horizons. Non-detectable selenium values $(<0.20$ $\mathrm{mg} / \mathrm{kg}$ are not included in graph. 60

Figure 5-2 Comparison of selenium concentration for shales situated more or less than 2 ft from coal beds. Non detectable selenium values $(<0.20$ $\mathrm{mg} / \mathrm{kg}$ ) are not included in graph

Figure 5-3 Relationship between total selenium and distance from coal beds for shales.

Figure 5-4 Plot of total $S$ against sum of extracted selenium for coal. Samples having extracted selenium below the detection limit $(<0.20 \mathrm{mg} / \mathrm{kg})$ are not included in graph.

Figure 5-5 Plots of the percentage of selenium extracted from (a) organic (F4) and (b) sulfide (F5) fractions in shale. Samples where extracted selenium is below the detection limit are not included in graph........ 
Figure 5-6 Plots of the percentage of selenium extracted from the (a) organic (F4) and (b) sulfide (F5) fractions in coal. Samples where extracted selenium is below the detection limit are not considered in graph.... 70 


\section{List of Acronyms}

$\begin{array}{ll}\text { ABA } & \text { acid base accounting } \\ \text { ADTI } & \text { acid drainage technology initiative } \\ \text { ASTM } & \text { American Society for Testing and Materials } \\ \text { EPA } & \text { Environmental Protection Agency } \\ \text { GFAAS } & \text { graphite furnace atomic absorption spectroscopy } \\ \text { HFMO } & \text { hydrous ferrous and manganese oxides } \\ \text { KCl } & \text { potassium chloride } \\ \text { ppm } & \text { parts per million } \\ \text { MPA } & \text { maximum potential acidity } \\ \text { MTM } & \text { mountaintop mining } \\ \text { NP } & \text { neutralization potential } \\ \text { NNP } & \text { net neutralization potential } \\ \text { REIC } & \text { Research Environmental \& Industrial Consultants Inc. } \\ \text { S } & \text { sulfur } \\ \text { Se } & \text { selenium } \\ \text { TOC } & \text { total organic carbon } \\ \text { USEPA } & \text { United States Environmental Protection Agency } \\ \text { VF } & \text { valley fills } \\ \text { WVGES } & \text { West Virginia Geological and Economic Survey } \\ \end{array}$




\section{Chapter 1 Introduction}

\subsection{Statement of problem}

Selenium (Se) is an environmentally important Clean Air Act, Title III Hazardous Air Pollutant of considerable environmental concern. However, it is also a required micronutrient for biota. Depending on its concentration, Se can be either essential or toxic to living beings (Butterman and Brown, 2004). Problems associated with Se first came to public attention in the 1930's, when studies in the western and great plains regions of the United States showed many areas with elevated levels of Se in plants like milk vetches and poison vetches that were sufficiently high to be toxic to animals (Bernhard and Bock, 1996). In the early 1980's, Se problems from agricultural waters that drained into Kesterson National Wildlife Refuge in California's San Joaquin Valley led to investigations in other parts of the United States and to increased regulations from federal and state governments (Presser, 1994). Surface mining activities have been characterized as being potentially harmful because of serious issues such as those associated with the Kesterson Wildlife Refuge in California (Sharmasarkar and Vance, 2002).

Se occurs naturally in the environment and can be released by both natural and humancaused processes. Rocks are one of the primary sources of Se that may eventually accumulate in soil, water and plants. Se is released in the environment through weathering, coal combustion, mining and incineration of municipal wastes. The most widespread causes of Se mobilization and introduction into the aquatic ecosystem in the U.S. today are the extraction and utilization of coal for generation of electric power and the irrigation of high Se soils for agricultural production (Nelson and Bundy, 1980).

Se in water may be a byproduct of mining as Se bearing overburden is exposed to weathering. An environmental impact study was done by the Environmental Protection Agency (USEPA) to characterize and compare impacts to stream chemistry from 
mountaintop mines and associated valley fills (MTM/VF) of West Virginia. High Se concentrations were found in streams impacted by mountaintop removal (USEPA, 2002). All violations of the stream concentration limit of $5 \mathrm{ug} / \mathrm{L}$ occurred in reaches downstream from the valley fills.

West Virginia Geological and Economic Survey (WVGES) and USEPA data report Se concentration in some coal beds of West Virginia (WVGES, 2002a, b) as well as in streams (USEPA, 2002). Se concentrations as high as $20 \mathrm{mg} / \mathrm{kg}$ are present in coals of some southern West Virginia counties (WVGES, 2002b). To date, most of the research on Se has been conducted in western United States. These assessments might not be the same in case of eastern US states where different stratigraphic units, rock types and coal beds are encountered (Neuzil et al., 2005). A better understanding of the distribution of Se by rock type and formation as well as an understanding of its extraction potential can be used to better prevent future impacts on surface water.

\subsection{Purpose and objectives}

The present research is designed to understand how Se is chemically bound in coals and coal-related lithologies. The present study evaluated Se binding in different rock types and their effect on extraction. The specific research objectives that were addressed include:

- to evaluate total Se concentration in relation to rock type, stratigraphy and other chemical parameters for a single rock core,

- to determine pattern of distribution of Se through a rock core,

- to identify Se modes of occurrence in different lithologies, and

- to determine relative Se extracted from different fractions of a rock. 


\section{Chapter 2 Literature review}

\subsection{Environmental geochemistry of selenium}

The narrow gap of dietary intake between necessary and toxic concentrations of Se (0.04$4 \mathrm{mg} / \mathrm{kg})(\mathrm{McNeal}$ and Balistrieri, 1989) makes it imperative to understand the mechanisms controlling the distribution of this element in the environment. Because of its similar ionic radius to sulfur (S), Se can readily substitute for $\mathrm{S}$ in both organic and inorganic compounds. In spite of having similar biogeochemical properties, Se and S follow distinct geochemical pathways near or at the surface during weathering (Lakin and Davidson, 1973). After weathering, Se commonly is fixed in insoluble basic ferric selenites, whereas $\mathrm{S}$ oxidizes to highly soluble sulfates that can be removed by surface and groundwater.

Se can exist in the $2^{-}, 0,4^{+}$, and $6^{+}$oxidation states. The concentration, speciation, and association of Se depend on $\mathrm{pH}$, oxidation-reduction (redox) potential, chemical and mineralogical composition, biological interactions, dissociation constants and reaction kinetics (Lussier et al., 2003). Selenide $\left(\mathrm{Se}^{2-}\right)$ and elemental $\mathrm{Se}\left(\mathrm{Se}^{0}\right)$ are generally favored in reducing environments, selenite $\left(\mathrm{SeO}_{3}{ }^{2-}\right)$ in mildly oxidizing environments, and selenate $\left(\mathrm{SeO}_{4}{ }^{2-}\right)$ in well-oxidized environments (Figure 2-1). The toxicity of Se varies with valence state and water solubility of the compound in which it occurs (Opresko, 1993). Generally the more oxidized forms of Se are more mobile and less toxic than the reduced forms. Therefore, the selenite and selenate species of Se are transported easily and pose less toxicity compared to the selenide and elemental Se. Solubility of Se has been shown to increase with the presence of organic acids, polysulfide ions, and increasing $\mathrm{pH}$ (Weres et al., 1989). 


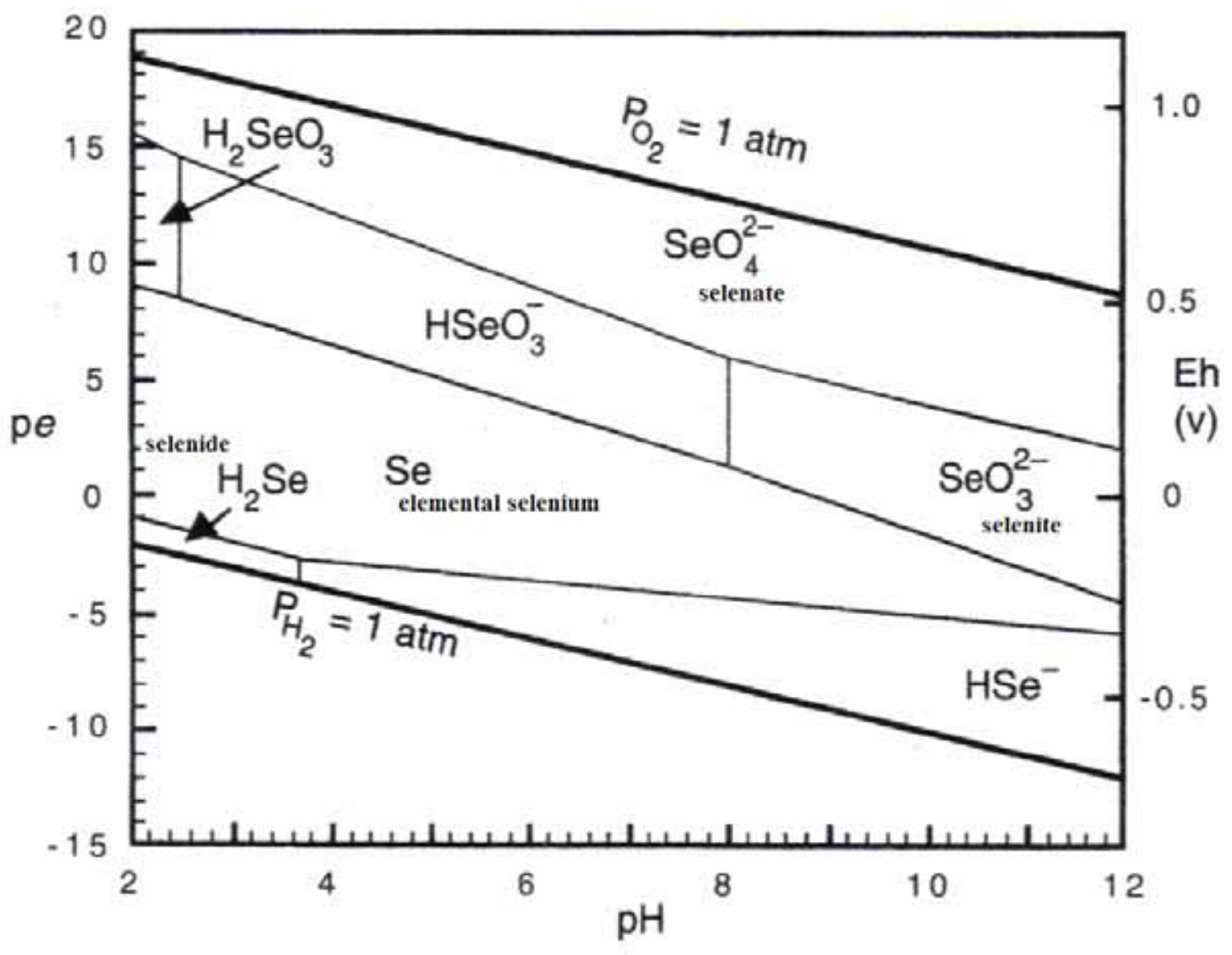

Figure 2-1 pH-Eh diagram for selenium (Drever, 1998) 


\subsection{Distribution and prediction of total selenium in rocks}

\subsubsection{Selenium sources and distribution by location and rock type}

Se is found in soils and rocks at concentrations up to several hundred parts per million (ppm) by way of igneous intrusions and by volcanism (Dreher and Finkelman, 1992). Seleniferous sedimentary materials are generally the greatest geological source of Se (Coleman and Delevaux, 1957). The Se content can vary from one rock type to another (Table 2-1).

Coal and highly organic rich sediments tend to have higher concentrations of Se than other rock types, presumably due to adsorption or organic matter complexation of Se and sulfides (Kunli et al., 2004). Se can be found in coal up to 82 times its concentration in the crust (US National Committee for Geochemistry, 1980). Coal on average contains from 5 to 300 times the amount of Se as other rocks. Se occurs in coal primarily within host minerals, most commonly associated with pyrite $\left(\mathrm{FeS}_{2}\right)$. Limestone and sandstone tend to have low concentrations of Se $(<0.1 \mathrm{mg} / \mathrm{kg})$. Shales usually tend to have higher Se concentration than limestone and sandstone $(0.6 \mathrm{mg} / \mathrm{kg})(\mathrm{McNeal}$ and Balistrieri, 1989).

The highest Se concentrations in the US Chemical Database (US National Committee for Geochemistry, 1980) are $75 \mathrm{mg} / \mathrm{kg}$ from a sample in Iowa and $52 \mathrm{mg} / \mathrm{kg}$ from a coal sample in West Virginia (Coleman et al., 1993). A study on the distribution of Se throughout the major provinces in the US reports that the average Se value for the eastern part of US is $4 \mathrm{mg} / \mathrm{kg}$ compared to $2 \mathrm{mg} / \mathrm{kg}$ for the western states and $3.6 \mathrm{mg} / \mathrm{kg}$ for the entire nation (Table 2-2). Se association in rocks (Dreher and Finkelman, 1992) and/or soils can be broadly attributed to the following modes of occurrence:

- in water soluble salts,

- adsorbed to clay surface, 
Table 2-1 Selenium concentration in major rock types based on 9000 samples collected from US coal regions and provinces (Coleman et al., 1993)

\begin{tabular}{c|c}
\hline \hline Rock Type & Se (mg/kg) \\
\hline US coal & 1.7 \\
soil & 0.4 \\
shale & 0.6 \\
argillaceous sediments & $0.4-0.6$ \\
sandstones & $0.05-0.08$ \\
limestones, dolomites & $0.03-0.10$ \\
ultramafic rocks & $0.02-0.05$ \\
mafic rocks & $0.01-0.05$ \\
intermediate rocks & $0.02-0.05$ \\
acid rocks (intrusive) & $0.01-0.05$ \\
acid rocks (extrusive) & $0.01-1.4$ \\
\hline
\end{tabular}


Table 2-2 Average, maximum and minimum concentrations of selenium in US coal regions and provinces (modified from Coleman et al., 1993)

\begin{tabular}{ccccc}
\hline Geographic areas & $\begin{array}{c}\text { no. of } \\
\text { samples }\end{array}$ & $\begin{array}{c}\text { average } \\
\text { (mg/kg) }\end{array}$ & $\begin{array}{c}\text { maximum } \\
\text { (mg/kg) }\end{array}$ & $\begin{array}{c}\text { minimum } \\
\text { (mg/kg) }\end{array}$ \\
\hline United States & 8695 & 3.6 & 75 & 0.02 \\
Provinces: & & & & \\
Eastern & 4711 & 4.2 & 75 & 0.02 \\
Gulf & 214 & 5.6 & 16 & 0.50 \\
Interior & 705 & 3.1 & 36 & 0.20 \\
Northern Great Plains & 1154 & 0.99 & 13 & 0.10 \\
Rocky Mountain & 1615 & 1.6 & 13 & 0.10 \\
Alaska & 258 & 1.1 & 43 & 0.10 \\
Pacific Coast & 38 & 1.9 & 7.3 & 0.20 \\
\hline
\end{tabular}

Note: All samples are coal 
- association with sulfides like galena $(\mathrm{PbS})$,

- in fine grained selenides such as clausthalite $(\mathrm{PbSe})$,

- in organic association, and

- bounded with hydrous ferrous and manganese oxides (HFMO).

\subsubsection{Total selenium in West Virginia rocks}

West Virginia Geological and Economic Survey (WVGES, 2002a) data suggest that the distribution of Se depends on stratigraphy and formation, rock type and where the rock is placed in the overall sequence. For rocks associated with coal bearing horizons, the partings, seat earth, roof shales and the bone coal are considered to be the formations that are referred to as the "toxic units" by Renton et al. (1989). These units are acidic and are more prone to extraction of metals and trace (Figure 2-2).

The average Se concentration in West Virginia coals (WVGES, 2002a) is $4.20 \mathrm{mg} / \mathrm{kg}$, having a maximum measured concentration of $21.30 \mathrm{mg} / \mathrm{kg}$ (Table 2-3). The coal seams of West Virginia belong to the Pennsylvanian Period. The geological units of this period are the Dunkard Group, Monongahela Group, Conemaugh Group, Allegheny Group, Kanawha Formation, New River Formation and the Pocahontas Formation. Of all these stratigraphic units, the middle Pennsylvanian Period comprising of the Allegheny Group, Kanawha Formation, and the Conemaugh Group have significant amount of Se in their coal beds (WVGES, 2002a) (Figure 2-3). These formations are often mined in southcentral West Virginia (WVGES, 2002a) (Figure 2-4).

Se concentration is reported for about 950 samples in the WVGES database in which $95 \%$ of the samples are coals (WVGES, 2002b). The highest Se concentration reported for coal is $21 \mathrm{mg} / \mathrm{kg}$ from the Stockton coal beds of the Kanawha Formation in Boone 


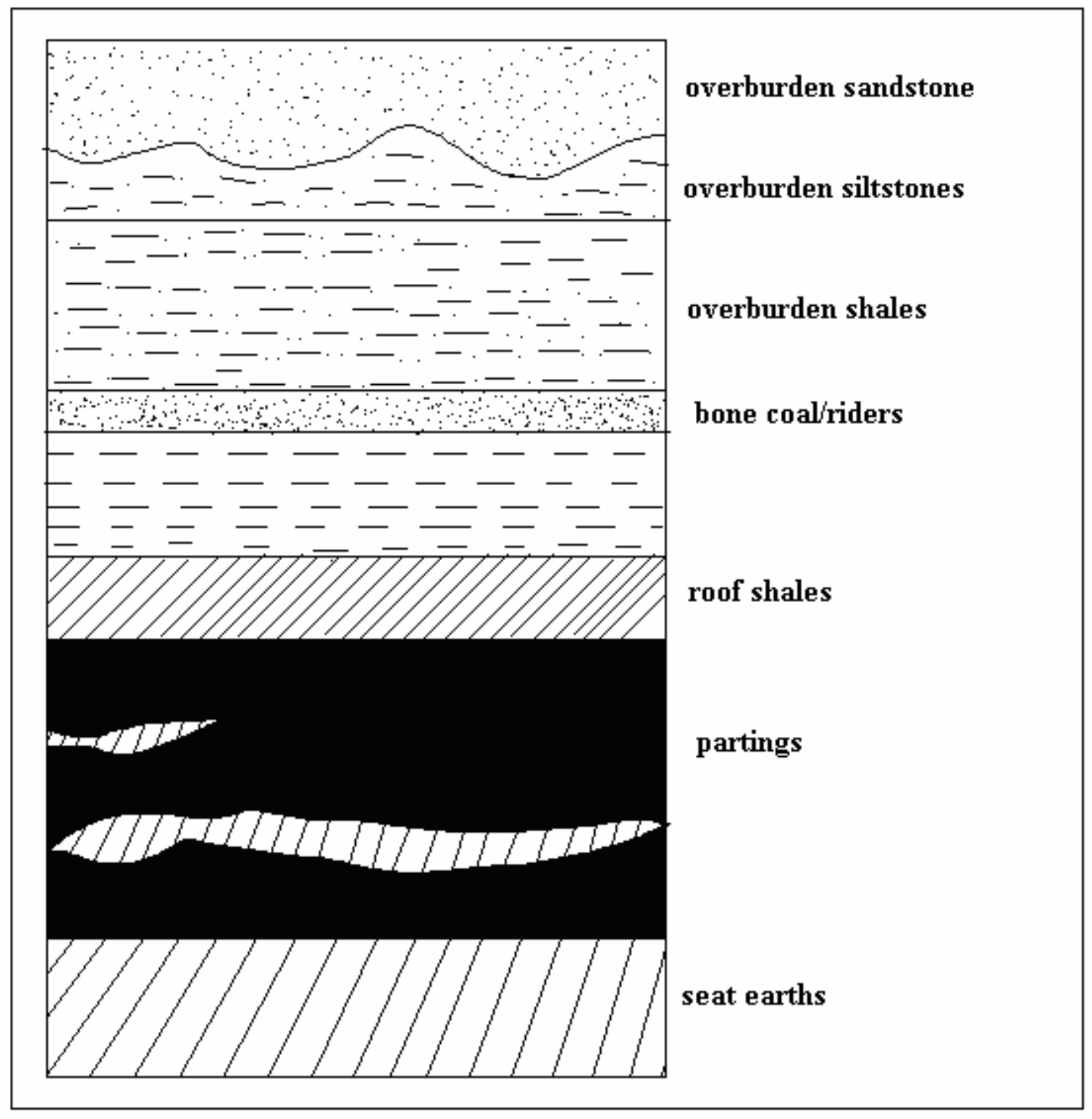

Figure 2-2 Potentially "toxic" or acidic units associated with coal (modified from Renton et al., 1989) 
Table 2-3 Summary statistics for selenium in West Virginia coals (WVGES, 2002a)

\begin{tabular}{|c|c|c|c|c|}
\hline $\begin{array}{l}\text { average } \\
(\mathrm{mg} / \mathbf{k g})\end{array}$ & $\begin{array}{c}\text { standard } \\
\text { deviation } \\
(\mathrm{mg} / \mathrm{kg})\end{array}$ & $\begin{array}{c}\operatorname{maximum} \\
(\mathrm{mg} / \mathrm{kg})\end{array}$ & $\underset{(\mathrm{mg} / \mathrm{kg})}{\operatorname{minimum}}$ & $\begin{array}{c}\text { no. of } \\
\text { analyses }\end{array}$ \\
\hline 4.20 & 2.83 & 21.30 & 0.00 & 845 \\
\hline
\end{tabular}




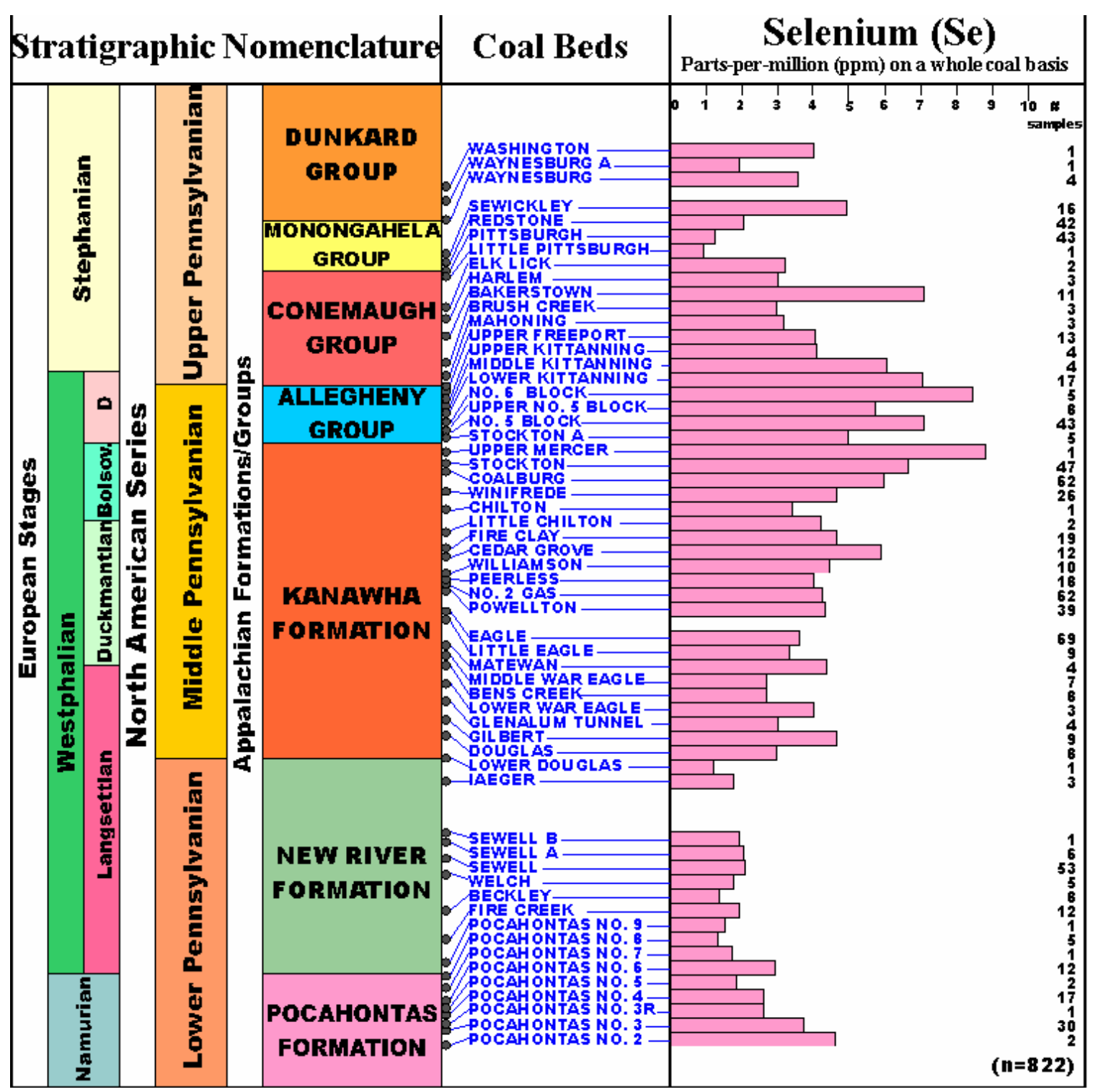

Figure 2-3 Stratigraphy and selenium content of coal beds in West Virginia

(WVGES, 2002a) 


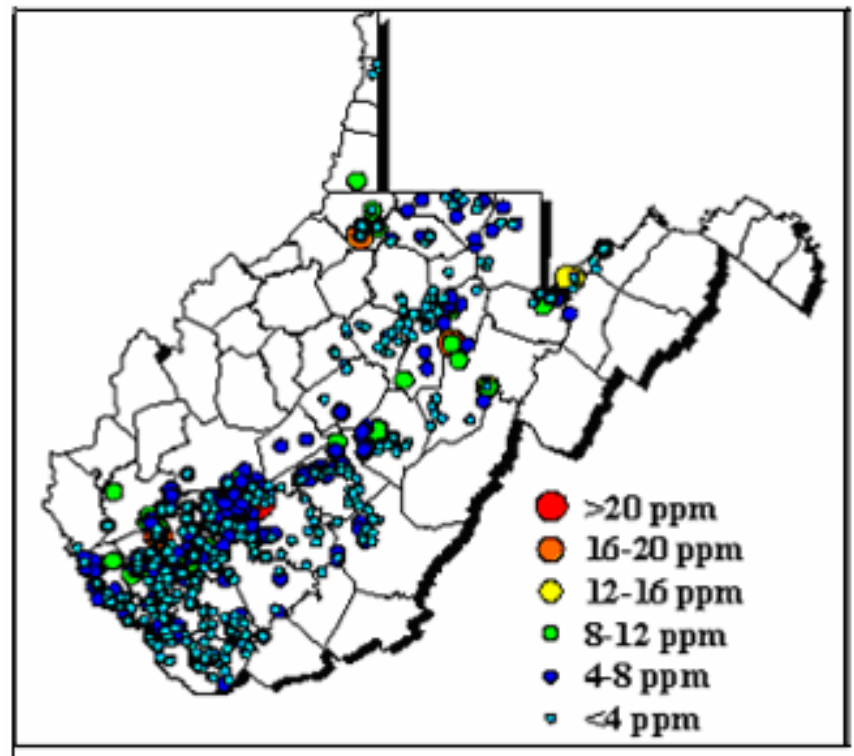

Figure 2-4 Geographic distribution of selenium in West Virginia coals (WVGES, 2002a) 
County of southcentral West Virginia. The lowest Se concentration in coal is from the Pittsburgh coal bed of the Monongahela Formation in Wetzel County. From this database it is also apparent that $<10 \%$ of the coal samples have total Se concentration $>10 \mathrm{mg} / \mathrm{kg}$ (Figure 2-5a). The highest Se concentration for mudstone is $14 \mathrm{mg} / \mathrm{kg}$ from Bens Creek coal bed of the Kanawha Formation in McDowell County, West Virginia and the lowest concentration is $<0.5 \mathrm{mg} / \mathrm{kg}$ from Little Chilton coal bed of the Kanawha Formation in Raleigh County (Figure 2-5b). In case of mudstone however, less than $15 \%$ of the samples have total Se concentration $>10 \mathrm{mg} / \mathrm{kg}$.

Mullennex (2005) studied the distribution and occurrence of Se in rock cores from a mine in southwestern West Virginia. According to his report, from over 400 rock samples, the highest total Se concentrations are found in coals and shales (Figure 2-6). All the high concentration non-coal lithotypes are situated in close proximity (within $5 \mathrm{ft}$ ) of the coal beds. The non-coal lithotypes include shale, sandstone and other rocks associated with coal units in a coal bed formation. His data are focused on the No. 5 and No. 6 Block coals of the Allegheny Formation and the Stockton and Coalburg coal beds of the Kanawha Formation. Sandstones have the lowest total Se concentration.

\subsubsection{Relationship between total selenium concentration and other chemical parameters}

Total Se concentrations might have some relationship to acid base accounting (ABA) parameters. The data generated from ABA might help to determine factors that control the distribution of total Se in different rock types. This method is designed to measure neutralization potential (NP) and sulfur content of individual overburden strata (Skousen et al., 2002). 

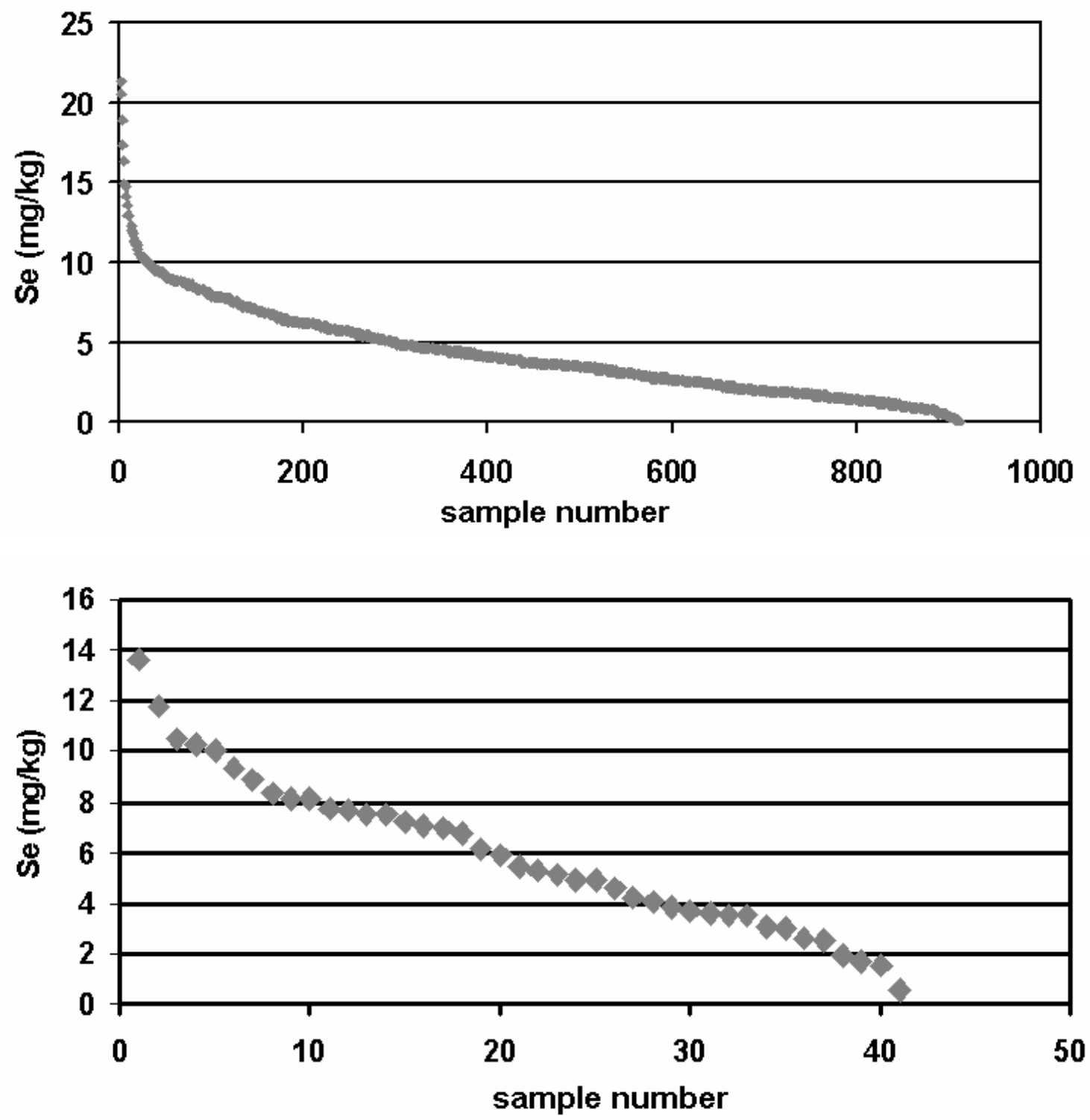

Figure 2-5 Distribution of selenium concentration in West Virginia (a) coals and (b) mudstones. Graphs generated using data from WVGES (2002b). 


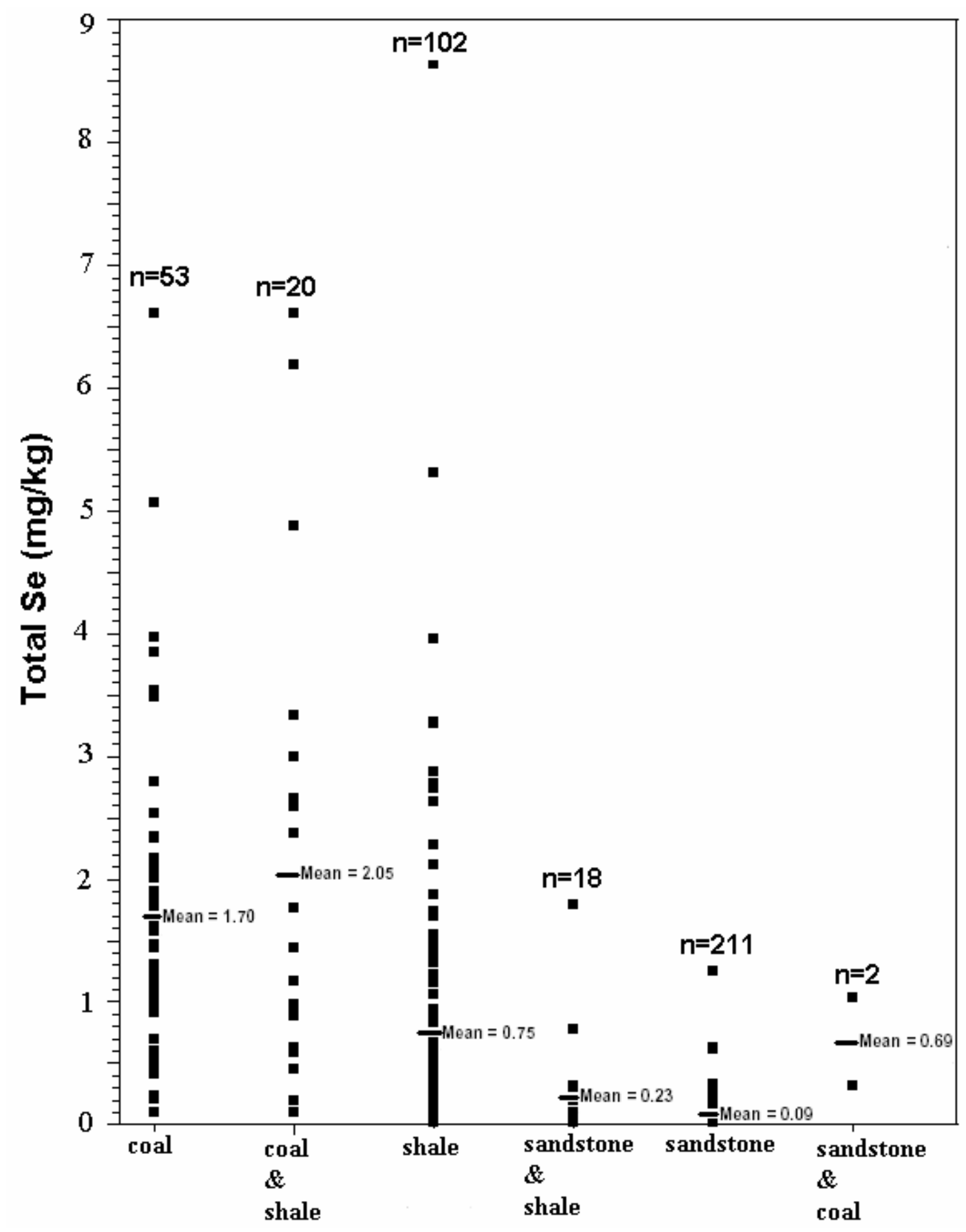

Figure 2-6 Distribution of selenium in various rock types from a mine in south western West Virginia (modified from Mullennex, 2005) 
From these measurements, maximum potential acidity (MPA) and net neutralization potential (NNP) are calculated for each geologic layer from the surface of the land down to, including, and immediately underlying the coal seam. A positive NNP indicates potentially alkaline producing strata in the overburden whereas a negative NNP indicates that the rock strata gives rise to potentially acidic overburden thus enhancing its ability to leach out metals and trace metals from the rock surface.

Sulfur generally occurs in one of three forms in rock strata associated with coals: pyritic sulfur, organic sulfur and sulfate sulfur (Rait et al., 2005). Pyritic sulfur is that sulfur that reacts with oxygen and water to produce acidity. Organic sulfur is that sulfur which occurs in carbon based molecules in coal and other rocks with significant carbon content. Sulfate sulfur occurs in partially weathered samples as a reaction by product of sulfide mineral oxidation. All these forms of sulfur contribute towards the calculation of the MPA factor in ABA.

\subsection{Weathering of selenium-containing rocks}

The primary source for Se is the weathering of rocks containing Se. Numerous factors can lead to the dissolution of these rocks thus increasing the chance of Se contamination.

Dreher and Finkelman (1992) suggested the source, occurrence and fate of Se in overburden deposits and backfill water are important in understanding Se chemistry in coal-mine environments. During surface coal mining, rock materials overlying the coal are redistributed from their original stratigraphic position and are often placed in oxygenated environments. The stability of Se-containing sulfides and organic matter can be substantially decreased by exposing buried horizons to surface oxidizing conditions which in turn can increase the potential solubility of Se species (Vance et al., 1995). Natural organic solutes in coal mine backfill groundwater systems have the potential to 
compete for adsorption sites on metal oxides, thus increasing the solubility of Se; though in case of extraction studies hydrous oxides do not play a significant role. Studies involving backfill and overburden materials indicate that organic solutes are important to Se chemistry because of the accompanying redox effects (Naftz and Rice, 1989; Dreher and Finkelman, 1992; Sharmasarkar and Vance, 1997).

To date, most studies on Se extraction have focused on soils and sediments (Chao and Sanzolone 1989, Wright et al., 2003). Lussier et al. (2003) observed that extraction of Se from coal bearing horizons is most pronounced from the sulfide and organic fractions. The Se concentration in these two fractions is controlled by depositional environment or by redox conditions. Se extracted from the sulfide fraction has been considered of special concern as it can be mobilized through exposure to air and water.

Various experiments can be used to study extraction mechanisms. Among these, the use of sequential extraction techniques to fractionate metals in solid materials into several groups of different leachability and evaluate their potential effects has become widely used and well recognized (Tessier et al., 1979; Chao and Sanzolone, 1989; Chao, 1984). The results furnish detailed information about the origin, mode of occurrence, bioavailability, potential mobility, and transport of the metals in natural environments (Shiowatana et al., 2001a).

The process of sequential extraction is used for metal and trace metal extraction and speciation and involves the use of chemical extractants that selectively dissolve the different chemical constituents of the sample material (Tessier et al., 1979; Chao, 1984). The method operationally defines the different major carriers of metals and trace metals and provides information on the metal-particle bonding mechanisms. The chemistry of redox labile elements such as $\mathrm{As}, \mathrm{Hg}$ and Se may be productively probed using sequential extraction procedures because the variation in oxidation number gives rise to more discrete and often nonlabile geochemical phases that might be selectively dissolved or extracted if the extracting reagents are judiciously chosen (Wright et al., 2003). Being operationally defined procedures, sequential procedures give results that are dependent 
on the extraction parameters such as type, concentration, $\mathrm{pH}$ of each reagent, sample weight to extractant volume ratios, extraction times and temperature, methods of shaking and phase separation, etc. (La Force and Fendorf, 2000).

For extracting conditions, it has been shown (Shiowatana et al., 2001b) that reagent concentration can affect extractability for some elements, especially trace elements, and should be selected carefully. Davidson et al. (1999) indicated that differences in extraction $\mathrm{pH}$ are an important source of variation in analytical results.

Chemical fractionation (operationally defined chemical speciation by sequential extraction) has been widely accepted and applied. However this technique has several limitations because of poor selectivity of reagents toward the targeted solid materials (Shiowatana et al., 2001a) or other artifacts that fail to preserve the insitu chemistry of the sample (Wright et al., 2003). Sequential extraction can also suffer from inaccuracy due to operational inconsistency during extraction and solid-liquid phase separation procedures. Errors resulting from readsorption during extraction have also been reported (Kheboian and Bauer, 1987). Despite these drawbacks, partial extractions have been used with considerable success to obtain information on the bioavailability and the geochemistry of trace metals (Tessier et al., 1979). Conditions and reagents used in chemical fractionation procedures are rarely encountered in real life conditions and are thus not always applicable to natural geological settings. The purpose of the extractions is to evaluate the chemical mode of occurrence and is not meant to directly estimate mobility in nature.

Chemical fractionation through sequential extraction operationally defines the soluble, adsorbed, oxide, organic and sulfide fractions but all these fractions are derived from different original sources. Se may be present in the organic or sulfide fractions due to original depositional or diagenetic processes. However, Se in the exchangeable, oxide and sorbed fractions are likely to be present due to later weathering processes (Figure 27). 


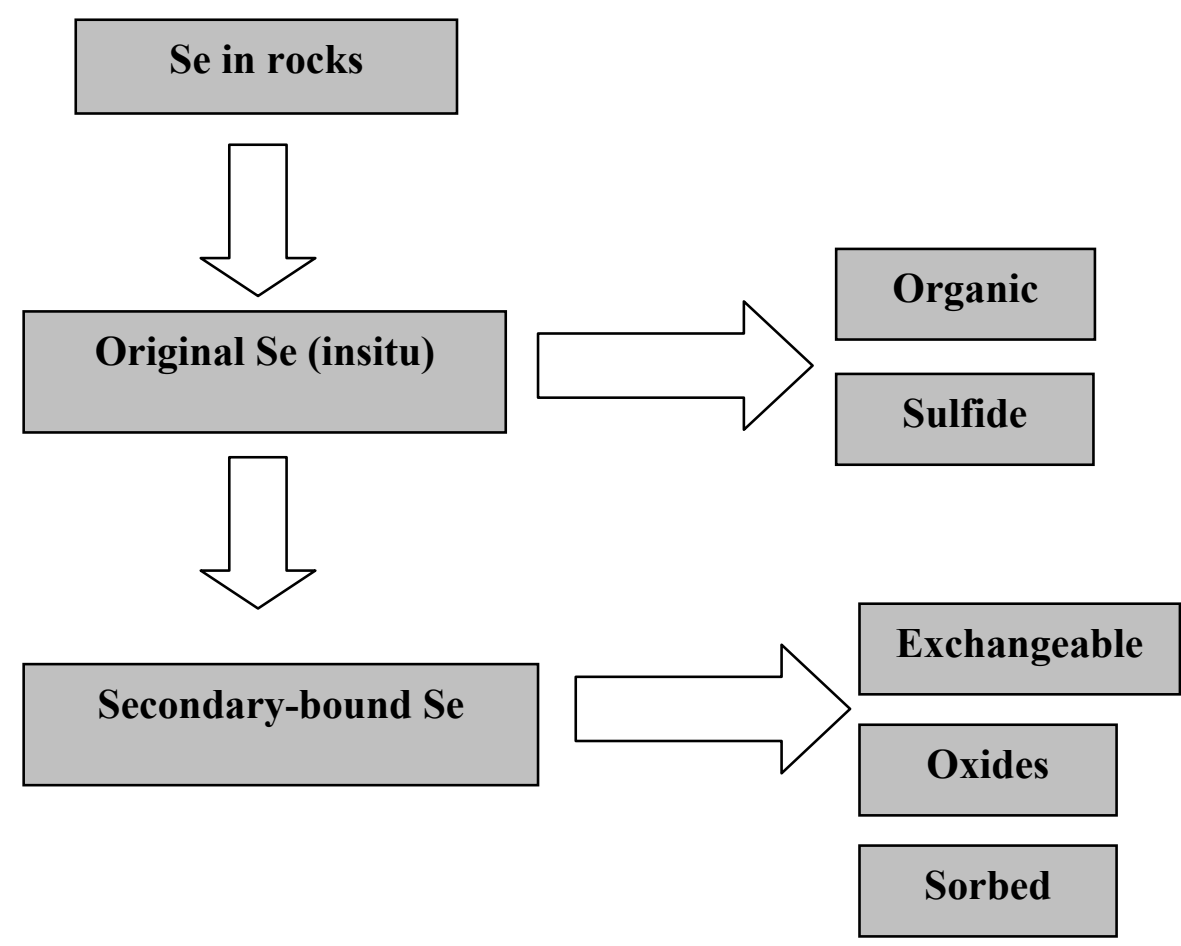

Figure 2-7 Mode of selenium binding in rocks 


\section{Chapter 3 Materials and methods}

\subsection{Nature and source of samples}

The samples for the present study were sedimentary rocks including coal, shale, sandstone, mudstone, and "carbolith" materials. "Carbolith" materials include dark colored sedimentary rocks with very high carbon (C) content. Rocks under this name include coal not scheduled for mining, bone coal, siltstones, and high $\mathrm{C}$ shales. The samples were analyzed from a donated rock core from Boone County, West Virginia. The rock core was used in this research to compare how Se extraction varies by rock type and stratigraphic location. Ground rock samples as well as some existing preliminary chemical data were made available by Research Environmental and Industrial Consultants, Inc. (REIC) Laboratory in Beaver, West Virginia (Table 3-1).

Discrete samples were collected from each lithologic unit (Keeney, 2005). For lithologic units that were less than 6-inch thick, the entire content was ground and composited. For lithologic unit up to 2-ft thick, three one-inch subsamples were collected from the top, middle and bottom on the unit. These subsamples were then ground and composited. For lithologic units greater than 2-ft in thickness, each 2-ft interval was sampled, ground and composited using 3 subsamples as per the 2-ft units. This sampling strategy was chosen so that the analytical samples represented individual lithologic units. From each composite, a subsample was taken and pulverized to less than 60 mesh in size. All of the sampling and grinding was conducted by REIC Laboratory before the samples were given to the research team. The major reasons for crushing samples were:

- to reduce the bulk (amount) of geological sample,

- to provide an unbiased, statistically representative sample of small quantity which can be used for analysis, and

- to reduce samples to a small size fraction that maximizes surface area and minimizes the analytical time 
Table 3-1 Sample description by rock type and available existing bulk data

\begin{tabular}{c|c|c|c|c|c|c|c}
\hline \hline \multicolumn{2}{c|}{ Rock description } & \multicolumn{6}{c}{ Available data } \\
\hline $\begin{array}{c}\text { no. of } \\
\text { samples }\end{array}$ & lithology & ABA & $\begin{array}{c}\text { Paste } \\
\text { pH }\end{array}$ & TOC & Pyritic S & Organic S & Total Se \\
\hline 11 & Coal & $\bullet$ & $\bullet$ & $\bullet$ & 0 & 0 & $\bullet$ \\
25 & Shale & $\bullet$ & $\bullet$ & $\bullet$ & 0 & 0 & $\bullet$ \\
9 & Mudstone & $\bullet$ & $\bullet$ & $\bullet$ & 0 & 0 & $\bullet$ \\
12 & Sandstone & $\bullet$ & $\bullet$ & $\bullet$ & 0 & 0 & $\bullet$ \\
6 & Carbolith & $\bullet$ & $\bullet$ & $\bullet$ & 0 & 0 & $\bullet$ \\
\hline
\end{tabular}

Notes: ABA: Sobek Method (EPA-600/2-78-05); Pyritic S/Organic S: American Standard Testing Method (ASTM) D2492; Total Organic Carbon (TOC): EPA 9060A; •: Available for all; O: Available for some; $\square$ : Available for none 
The crushed samples were weighed and stored in air tight containers until further analysis. The samples were from the Kanawha Formation and belonged to the Coalburg, Winifrede Rider, Upper Winifrede and Winifrede coal beds.

\subsection{Existing chemical data provided with samples}

The samples were analyzed for some chemical parameters by REIC Laboratory and the data were made available for the purpose of this research. One of these chemical parameters was ABA (Appendix 1: Table A-1). This method gives an account of the $\mathrm{S}$

content, NP and MPA of the individual overburden strata encountered in the studied rock core.

Sulfur fractionation data were made available primarily for coal and its overburden (Table 3-2). S fractionation was done at REIC Laboratory using American Society for Testing and Materials (ASTM) D2492. This test method applies to the determination of sulfate sulfur and pyritic sulfur in coal and calculates organic sulfur by difference.

\subsection{Additional laboratory analysis of solid samples}

The total Se in the solid rock samples was analyzed at REIC Laboratory using the graphite furnace atomic absorption spectroscopy (GFAAS) according to EPA Method 270.2. The analysis followed a total rock digestion with nitric acid $\left(\mathrm{HNO}_{3}\right)$ and hydrogen peroxide $\left(\mathrm{H}_{2} \mathrm{O}_{2}\right)$ according to EPA Method 3050B.

TOC was analyzed at REIC Laboratory by the combustion process according to EPA Method 9060A. 
Table 3-2 Sulfur fractionation data

\begin{tabular}{cccccc}
\hline \hline Sample No. & Rock Type & $\begin{array}{c}\text { Total S } \\
(\%)\end{array}$ & $\begin{array}{c}\text { Pyritic S } \\
(\%)\end{array}$ & $\begin{array}{c}\text { Organic S } \\
(\%)\end{array}$ & $\begin{array}{c}\text { Sulfate S } \\
(\%)\end{array}$ \\
\hline 9 & Sandstone/Coal & 0.20 & 0.08 & 0.12 & $<0.01$ \\
16 & Shale & 0.85 & 0.52 & 0.15 & 0.18 \\
$16 \mathrm{~A}$ & Coal & 6.22 & 2.70 & 2.65 & 0.87 \\
17 & Mudstone & 1.22 & 0.70 & 0.14 & 0.38 \\
18 & Sandstone & 0.88 & 0.53 & 0.13 & 0.22 \\
33 & Sandstone & 0.54 & 0.23 & 0.19 & 0.12 \\
$37 \mathrm{~A}$ & Coal & 0.44 & 0.06 & 0.36 & 0.02 \\
$37 \mathrm{~B}$ & Coal & 0.76 & 0.02 & 0.68 & 0.06 \\
$50 \mathrm{~A}$ & Coal & 1.80 & 0.50 & 1.14 & 0.16 \\
51 & Shale & 1.34 & 0.57 & 0.45 & 0.32 \\
54 & Coal & 0.69 & 0.10 & 0.49 & 0.10 \\
57 & Carbolith/Shale & 0.37 & 0.05 & 0.22 & 0.10 \\
$57 \mathrm{~A}$ & Coal & 0.88 & 0.06 & 0.75 & 0.07 \\
$62 \mathrm{~A}$ & Coal & 0.60 & 0.06 & 0.46 & 0.08 \\
$63 \mathrm{~A}$ & Coal & 0.95 & 0.07 & 0.82 & 0.06 \\
$73 \mathrm{~A}$ & Coal & 0.68 & 0.05 & 0.63 & $<0.01$ \\
$73 \mathrm{~B}$ & Coal & 1.75 & 0.55 & 0.75 & 0.45 \\
74 & Shale & 0.37 & 0.06 & 0.19 & 0.12 \\
$76 \mathrm{~A}$ & Coal & 0.68 & 0.04 & 0.63 & 0.01 \\
\hline
\end{tabular}

Data from REIC Laboratory 


\subsection{Sequential extraction procedure}

The sequential extraction process for extracting Se is an "operationally defined" mechanism for monitoring the association of Se in rock cores, soils and sediments. The five-step sequential extraction procedure (Table 3-3) in this study was adapted from Martens and Suarez. (1997), Chao and Sanzolone (1989), Bascomb and Thanigasalam (1978) and Lynch (1970).

This method operationally measures six fractions of Se:

Fraction 1-Deionized Water: The most soluble Se in the rock core samples were extracted using deionized water. Five grams of the sample was placed in $50 \mathrm{~mL}$ centrifuge tubes followed by $25 \mathrm{~mL}$ of deionized water. The centrifuge tubes were tightly capped and shaken for 1 hour at $25^{\circ} \mathrm{C}$. Then the tubes were centrifuged at $10000 \mathrm{~g}$ for 15 minutes. The centrifugate was stored in a clean bottle. Then $5 \mathrm{~mL}$ of $0.25 \mathrm{M} \mathrm{KCl}$ was added to the centrifuge tube with the solid sample and it was centrifuged again. The $\mathrm{KCl}$ centrifugate was combined with the first centrifuged extraction solution.

Fraction 2-0.1M K $2 \underline{\mathrm{HPO}}_{4}$ : The residue from Fraction 1 was mixed with $25 \mathrm{~mL}$ of $0.1 \mathrm{M}$ $\mathrm{K}_{2} \mathrm{HPO}_{4}$ at $\mathrm{pH} 7$ and shaken for 1 hour at $25^{\circ} \mathrm{C}$ in a shaker. The centrifugate was treated identically as in Fraction 1. This step is interpreted to extract the adsorbed and exchangeable Se from the samples.

Fraction 3-0.1 $\mathrm{M} \mathrm{NH}_{2}$ OH.HCl: Hydrated ferrous and manganese oxides (HFMO) associated with the samples are interpreted to be extracted using hydroxylamine hydrochloride. The residue from Fraction 2 was mixed with $25 \mathrm{~mL}$ of $\mathrm{NH}_{2} \mathrm{OH} . \mathrm{HCl}$ in a centrifuge tube and heated to $90^{\circ} \mathrm{C}$ followed by shaking for 2 hours in a shaker. The centrifugate was treated identically as the other fractions. 
Table 3-3 Sequential extraction procedure used in the study

\begin{tabular}{l|c|c|c}
\hline $\begin{array}{l}\text { step } \\
\text { no. }\end{array}$ & extraction solution & type of reaction & fraction targeted \\
\hline 1 & Deionized water $\left(\mathrm{H}_{2} \mathrm{O}\right)$ & Dissolution & $\begin{array}{c}\text { Soluble } \\
\text { Martens and Suarez. } \\
(1997)\end{array}$ \\
\hline 2 & $\begin{array}{c}\text { Potassium Hydrogen Phosphate } \\
\left(\mathrm{K}_{2} \mathrm{HPO}_{4}\right)\end{array}$ & Ion Exchange & $\begin{array}{c}\text { Exchangeable } \\
\text { Martens and Suarez } \\
(1997)\end{array}$ \\
\hline 3 & $\begin{array}{c}\left(\mathrm{NH}_{2} \mathrm{OH} . \mathrm{HCl}\right) \\
\text { Hydroxylamine hydrochloride }\end{array}$ & Reduction & $\begin{array}{c}\text { Oxide coatings, } \\
\text { typically iron and } \\
\text { manganese } \\
\text { Chao and Sanzolone } \\
(1989)\end{array}$ \\
\hline 4 & $\begin{array}{c}\text { Sodium pyrophosphate }\left(\mathrm{Na}_{4} \mathrm{P}_{2} \mathrm{O}_{7}\right) \\
\text { peroxide }\left(\mathrm{C}_{6} \mathrm{H}_{8} \mathrm{O}_{6} \text { and } \mathrm{H}_{2} \mathrm{O}_{2}\right)\end{array}$ & $\begin{array}{c}\text { Oxidation } \\
\text { (weaker) }\end{array}$ & $\begin{array}{c}\text { Organic compounds } \\
\text { Bascomb and } \\
\text { Thanigasalam (1978) }\end{array}$ \\
\hline 5 & $\begin{array}{c}\text { Oxidation } \\
\text { (stronger) }\end{array}$ & $\begin{array}{c}\text { Sulfide minerals } \\
\text { Lynch (1970) }\end{array}$ \\
\hline 6 & $\begin{array}{c}\text { Nitric acid and hydrogen peroxide } \\
\left(\mathrm{HNO}_{3}-\mathrm{H}_{2} \mathrm{O}_{2}\right)\end{array}$ & $\begin{array}{c}\text { Complete } \\
\text { dissolution of } \\
\text { solids }\end{array}$ & $\begin{array}{c}\text { Residual } \\
\text { Martens and Suarez } \\
(1997)\end{array}$ \\
\hline
\end{tabular}


Fraction $4-0.1 \mathrm{M} \mathrm{Na}_{4} \underline{\mathrm{P}}_{2} \underline{\mathrm{O}}_{7}$ : The residue from Fraction 3 was mixed with $25 \mathrm{~mL}$ of $0.1 \mathrm{M}$ $\mathrm{Na}_{4} \mathrm{P}_{2} \mathrm{O}_{7}$ in a centrifuge tube and shaken for 12 hours at room temperature. This step is interpreted to extract organically associated Se. The solution was centrifuged at $12000 \mathrm{~g}$ for 15 minutes. The centrifugate was treated identically as the other fractions. Extraction with $\mathrm{Na}_{4} \mathrm{P}_{2} \mathrm{O}_{7}$ should not release sulfides (Bascomb et al., 1978), which was a major factor behind choosing this particular chemical. Because of the highly dispersive state of the suspension as a result of adding the sodium pyrophosphate solution at $\mathrm{pH} 10$, a stronger centrifugation (12000 g) was necessary to separate the supernatant solution.

Fraction 5-0.1 $\mathrm{M} \mathrm{C}_{6} \underline{\mathrm{H}}_{8} \underline{\mathrm{O}}_{6}-30 \% \mathrm{H}_{2} \underline{\mathrm{O}}_{2}$ : The residue from Fraction 4 was treated with 25 $\mathrm{mL}$ of a mixture of $\mathrm{C}_{6} \mathrm{H}_{8} \mathrm{O}_{6}$ and $30 \% \mathrm{H}_{2} \mathrm{O}_{2}$ and shaken initially for 15 minutes. The solution was allowed to stand for 14 hours after which it was again shaken for 30 minutes. The solution was centrifuged at $10000 \mathrm{~g}$ for 15 minutes. The centrifugate was treated identically as in other fractions. The method is interpreted for extracting sulfide associated Se.

\subsection{Extraction solutions and residues}

The extraction solutions from the sequential extraction process were kept in a refrigerator until laboratory analysis. The solutions were analyzed for Se at Sturm Environmental Services of Bridgeport, West Virginia using the GFAAS method according to EPA Method 270.2. The detection limit for this method is $0.002 \mathrm{mg} / \mathrm{L}$.

The residues from Fraction 5 were also stored in a refrigerator for analyses of residual $\mathrm{Se}$ by the GFAAS method as per rock samples. 


\subsection{Calculations from raw data}

Analysis of extraction solutions from the sequential extraction process are reported in concentrations of mass per volume, typically $\mathrm{mg} / \mathrm{L}$. A series of calculations were done

(Figure 3-1) to compare the findings between samples of slightly different size and also to calculate the mass loss. The calculations were done for the following reasons

- The initial solid sample masses were not always 5 gms although most of them were within $0.01 \mathrm{gms}$ of the initial dry mass. The data were normalized to the initial dry weight to account for the variation of the initial masses.

- The extraction volumes differed in some of the fractions and so to make the final data comparable across all the fractions, concentrations were multiplied by solution volumes to obtain the extracted mass.

- The sum of the fractional concentrations including the residual fraction were compared to the total (single extraction) bulk concentration.

\section{Quality discussion of data}

For analysis of errors associated with the methods as well as from other sources, data quality issues were strictly monitored during the present study. The quality control procedures included the following:

Sample heterogeneity: All samples from the sequential extraction process were analyzed in replicates to consider sample heterogeneity. Sample compositing could account for some of the heterogeneity issues too. The $\%$ difference in the values ranged from less than $1 \%$ to greater than $50 \%$ in some cases (Appendix 1: Table A-3). To account for the variations, the mean values were used for interpretation. The interpretation was based on order of magnitude difference between the fractions. 


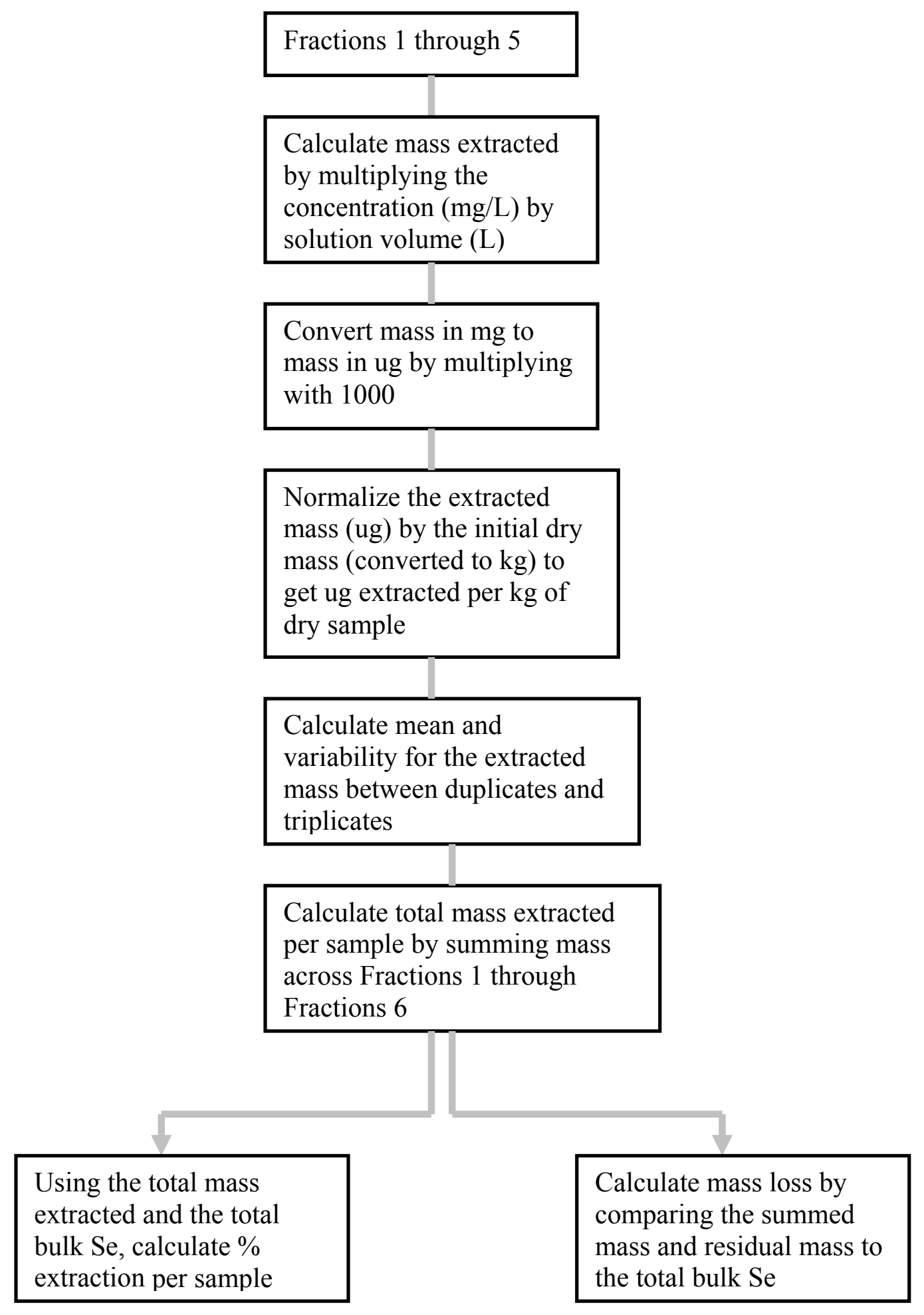

Figure 3-1 Calculations for the data from sequential extraction 
Sample contamination: To address procedure problems and check for sample contamination, process blanks and solution blanks were included with some of the analytical batches. The solution blanks were used to determine the background metals in the extraction solutions while the process blanks were empty centrifuge tubes subjected to similar extraction procedure along with other samples. Over $90 \%$ of the extraction samples had concentrations greater than the maximum concentration found in the solution blanks (Table 3-4). The low concentration of the solution blanks and process blanks only impacted samples with low Se concentrations.

Lab precision and accuracy: Blind standards were included with the analytical batches to check for accuracy of the analytical methods. Blind duplicates of the extraction solutions were also included to account for the precision of the analytical method and also checked for laboratory reproducibility. The blind standards matched reasonably well with the given concentrations. There was a difference of about 2 to $5 \%$ (Table 3-5) for some of the blind duplicates but this could be attributed to the noise within the analytical instruments and thus was not an appreciable source of error.

Separation of sulfide and organically bound selenium by fraction: Total S concentrations were measured in all fractions (F1 through F5) for six samples. This was done to determine if the extraction procedure was releasing $\mathrm{S}$ as designed by the methodology (that is within the $\mathrm{S}$ fraction or F5). Among the six samples that were analyzed for this purpose, the fraction with the highest concentration of S was F5 which was indeed the fraction intended for that purpose (Figure 3-2). The next highest mean value was for $\mathrm{F} 1$ which released the easily oxidizable and soluble $\mathrm{S}$. The lowest amount of S was released from the organic and oxide associated Se fractions (F4 and F3) respectively. This suggests that the organically and sulfide associated fractions of Se are being distinguished by this methodology. 
Table 3-4 Quality of data based on sample contamination issues

\begin{tabular}{cccc}
\hline Source material & no. of samples & $\begin{array}{c}\text { mean Se } \\
(\mathbf{m g} / \mathbf{L})\end{array}$ & $\begin{array}{c}\text { range } \\
(\mathbf{m g} / \mathbf{L})\end{array}$ \\
\hline Process Blanks & 39 & 0.01 & $<0.002-0.03$ \\
\hline Reagent Blanks & 10 & $<0.002$ & $<0.002$ \\
\hline Rock Samples & 395 & 0.50 & $<0.002-1.18$ \\
\hline
\end{tabular}


Table 3-5 Estimated analytical error based on blind replicates

\begin{tabular}{ccc}
\hline \hline Source & no. of samples & $\begin{array}{c}\text { error for Se } \\
\text { concentration } \\
\text { (\%) }\end{array}$ \\
\hline Blind standards & 15 & $0-3$ \\
Blind duplicates & 10 & $2-5$ \\
\hline
\end{tabular}




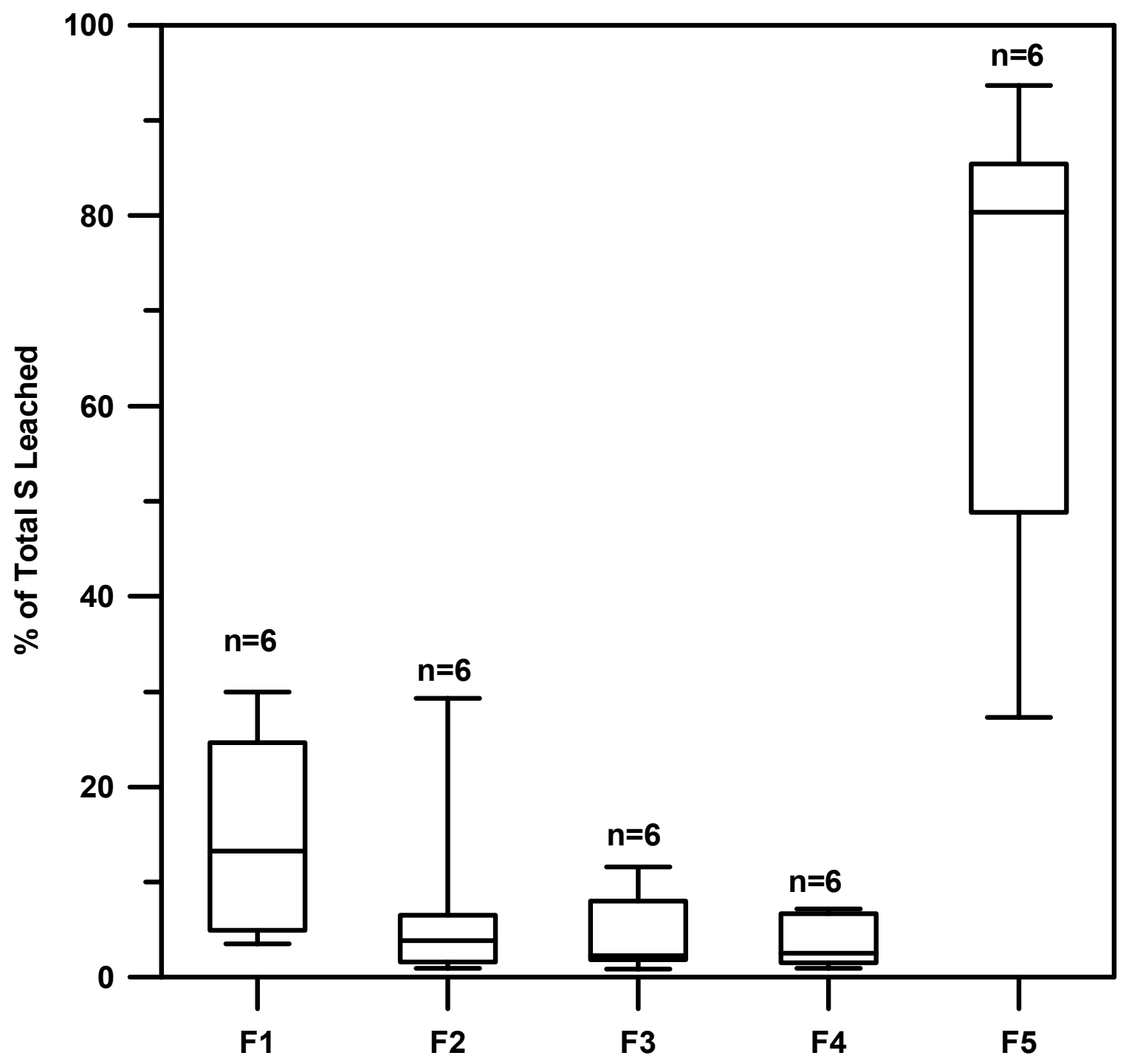

Figure 3-2 Separation of $\mathrm{S}$ in different fractions of the extraction solutions (F1 through F5) 


\section{Chapter 4 Results}

\subsection{Total bulk selenium in rock samples}

\subsubsection{Relationship between total selenium, stratigraphy and lithology}

The total bulk Se concentration in the rock core ranged from below detection limit $(0.20$ $\mathrm{mg} / \mathrm{kg}$ ) to $9.4 \mathrm{mg} / \mathrm{kg}$ (Table 4-1, Appendix 1: Table A-2). Concentration of total Se was not consistent by rock type (Figure 4-1). The highest concentration of total bulk Se was from a carbolith $(9.4 \mathrm{mg} / \mathrm{kg})$ while the lowest Se concentrations were from sandstones where most of the concentrations were below the detection limit of $0.20 \mathrm{mg} / \mathrm{kg}$ (Appendix 1: Table A-2). Shale and mudstones had similar distribution of the mean concentrations. Sandstones had the lowest range of values and the lowest mean. Overall the carboliths had higher mean concentrations and the greatest range of values.

The rocks in this core were from the Pennsylvanian Period and belonged to the Kanawha Formation. The total bulk Se concentration changed with depth in the core. The highest concentrations were found at depths between 210 feet to 226 feet and were from the Upper Winifrede coal beds (Figure 4-2). Most of the rock types that had no detectable Se or very low concentration of total Se were from the Coalburg coal beds. This suggests that the stratigraphy of the different rock units play a significant role in the distribution of the total bulk Se among the different rock types. 
Table 4-1 Comparison of total selenium and sum of extracted selenium fractions

\begin{tabular}{|c|c|c|c|}
\hline Sample ID & $\begin{array}{l}\text { Total Se } \\
\text { (mg/kg) }\end{array}$ & $\begin{array}{c}\text { Sum of extracted Se } \\
\text { and residual Se } \\
(\mathrm{mg} / \mathrm{kg})\end{array}$ & Rock type \\
\hline 34 & 0.40 & 0.39 & Shale \\
\hline 36 & 0.94 & 0.90 & Sandstone \\
\hline 35 & 0.52 & 0.65 & Shale \\
\hline 33 & 0.28 & 0.20 & Sandstone \\
\hline $37 \mathrm{~A}$ & 1.26 & 1.01 & Carbolith \\
\hline $38 \mathrm{~A}$ & 0.32 & 0.31 & Mudstone \\
\hline $39 A$ & 0.54 & 0.53 & Carbolith \\
\hline 48 & 0.30 & 0.30 & Shale \\
\hline 49 & 3.38 & 3.35 & Carbolith \\
\hline 37 & 3.72 & 3.23 & Sandstone/Carbolith \\
\hline $37 \mathrm{~B}$ & 0.42 & 0.43 & Coal \\
\hline 28 & 0.28 & 0.24 & Mudstone \\
\hline 27 & 0.24 & 0.21 & Mudstone/Sandstone \\
\hline 15 & 0.30 & 0.30 & Shale \\
\hline 16 & 0.42 & 0.37 & Shale \\
\hline $50 \mathrm{~A}$ & 1.16 & 1.35 & Coal \\
\hline 50 & 2.58 & 2.56 & Shale \\
\hline $57 \mathrm{~A}$ & 0.50 & 0.48 & Coal \\
\hline 57 & 7.12 & 7.07 & Carbolith \\
\hline 52 & 0.36 & 0.36 & Mudstone \\
\hline 54 & 1.00 & 0.85 & Coal \\
\hline 53 & 0.28 & 0.27 & Sandstone \\
\hline 55 & 0.26 & 0.26 & Shale \\
\hline 62 & 9.44 & 8.52 & Carbolith \\
\hline $62 \mathrm{~A}$ & 5.96 & 4.70 & Coal \\
\hline 61 & 1.06 & 0.95 & Shale \\
\hline 63 & 5.36 & 4.35 & Shale \\
\hline 73 & 1.18 & 1.11 & Coal \\
\hline 72 & 0.64 & 0.62 & Shale \\
\hline $73 B$ & 2.02 & 2.20 & Coal \\
\hline 77 & 2.08 & 0.50 & Mudstone \\
\hline $76 \mathrm{~A}$ & 2.06 & 2.04 & Coal \\
\hline 76 & 0.76 & 0.69 & Shale \\
\hline 74 & 1.00 & 0.94 & Shale \\
\hline 75 & 0.34 & 0.34 & Shale \\
\hline 51 & 1.16 & 0.96 & Shale \\
\hline 17 & 0.20 & 0.19 & Mudstone \\
\hline 78 & 0.30 & 0.42 & Mudstone \\
\hline 56 & 0.78 & 0.76 & Shale \\
\hline $63 \mathrm{~A}$ & 1.98 & 1.67 & Coal \\
\hline 70 & 0.24 & 0.17 & Shale \\
\hline
\end{tabular}

Note: Samples with no detectable total Se are not included here. See Table A-2 for full details. 


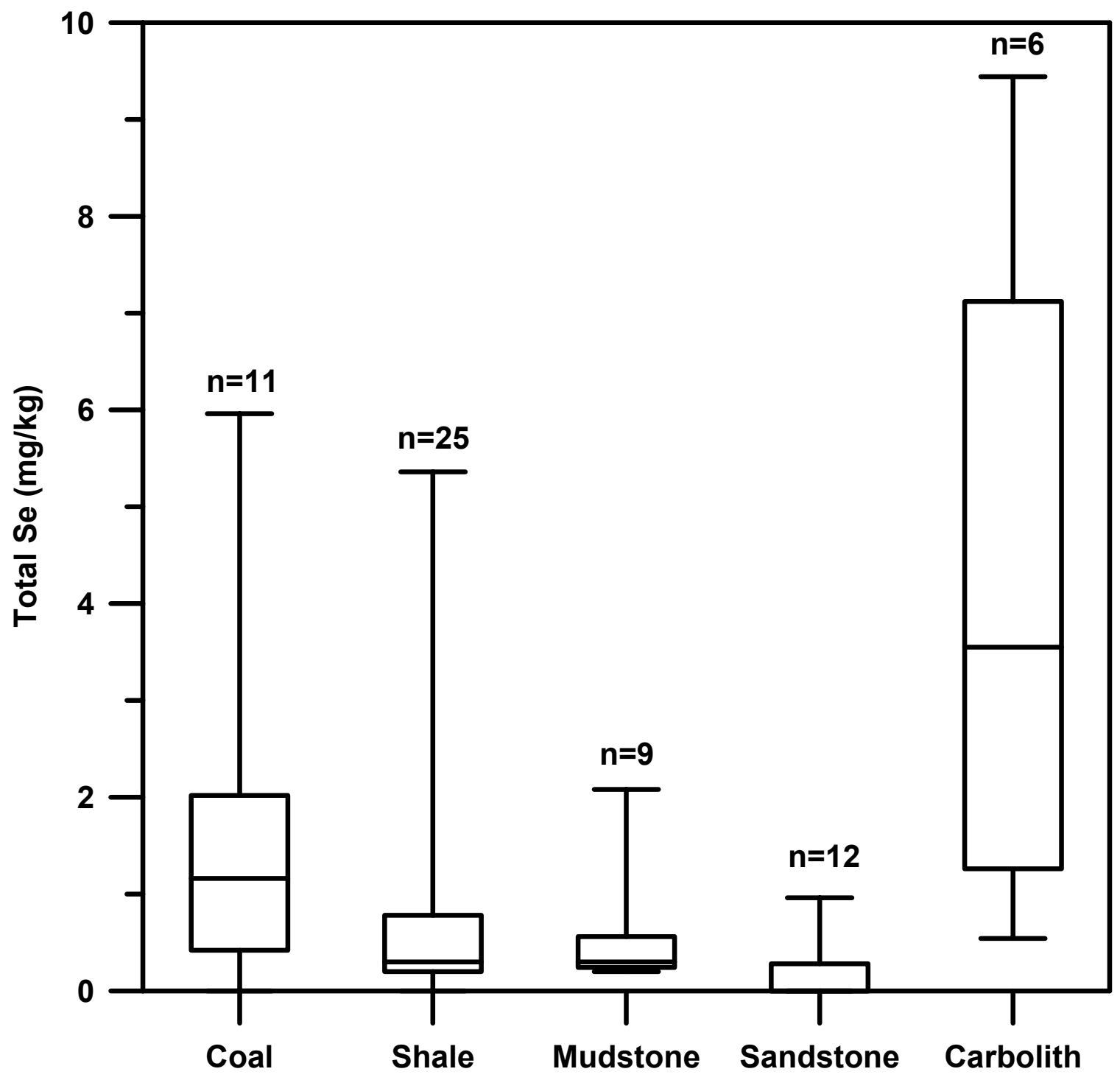

Figure 4-1 Distribution of total selenium in different rock types. Values less than $0.20 \mathrm{mg} / \mathrm{kg}$ are graphed as $0 \mathrm{mg} / \mathrm{kg}$. 


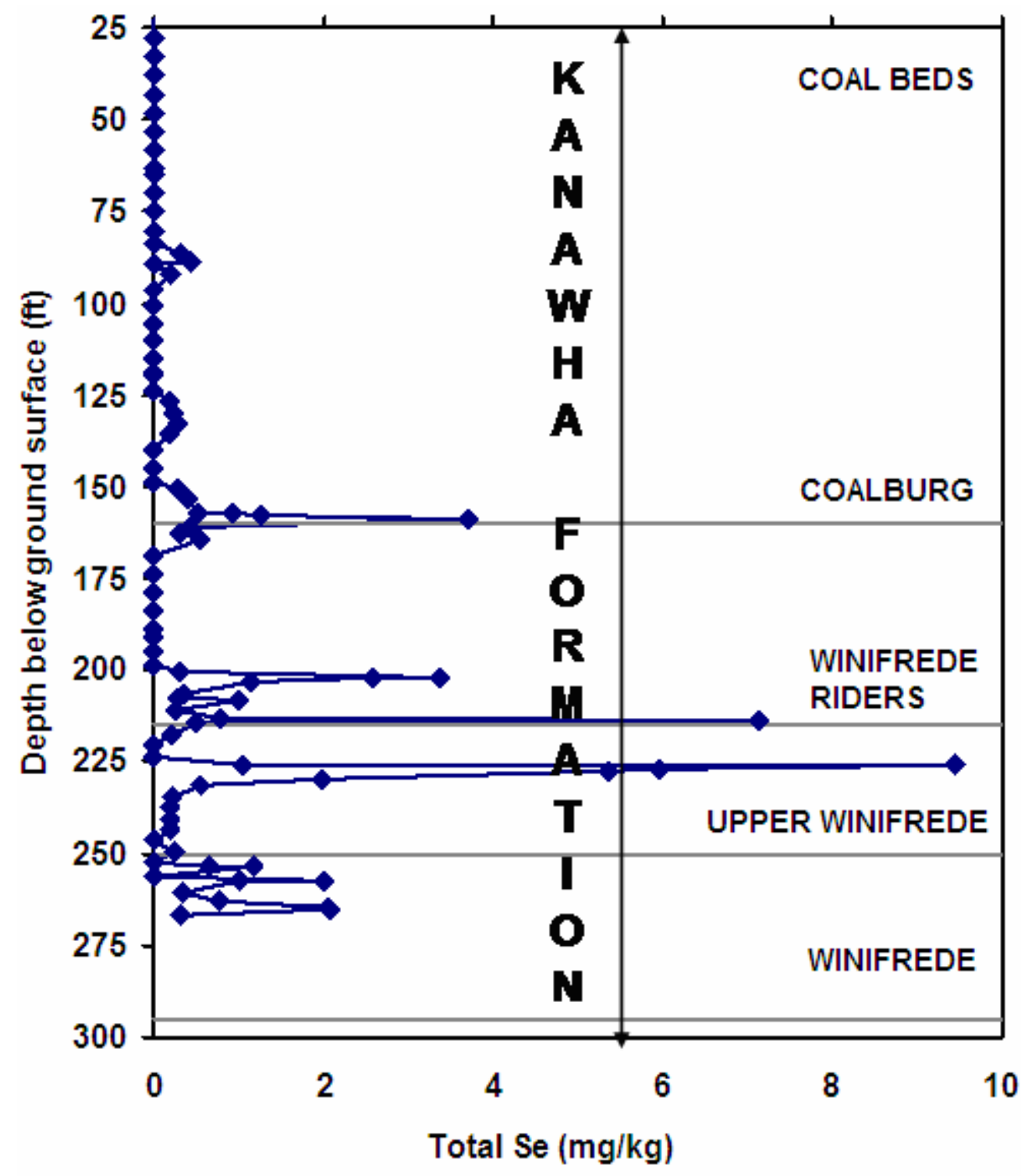

Figure 4-2 Distribution of total selenium with depth, formation and coal beds. Non-detectable values $(<0.20 \mathrm{mg} / \mathrm{kg})$ are graphed as $0 \mathrm{mg} / \mathrm{kg}$. 


\subsubsection{Relationship between total selenium and other parameters}

Various data were available for comparison to the Se concentration. In this section an effort has been made to evaluate the relationship between each of those chemical parameters and the Se concentration. Based on linear regression, it turned out that the only statistically significant correlation exists between log Se vs. $\log$ TOC where the alpha $(\alpha)$ values are less than 0.05 but not less than 0.01 . Log values were used for the linear regression because all the data were log normally distributed. The correlation was significant (at this alpha) for shale or the complete rock set, but not for coal. The corresponding $\mathrm{R}^{2}$ values were 0.59 for shale and 0.38 for the entire rock set. The total Se concentrations were not linearly related to the other bulk parameters; however, graphs of the dataset suggest that some other relationships may exist. These are presented in the following section.

Total selenium and paste $\mathrm{pH}$ : The paste $\mathrm{pH}$ values for the rock core samples ranged from 4 to 8.5. All samples that had a total Se concentration greater than $2 \mathrm{mg} / \mathrm{kg}$ had paste $\mathrm{pH}$ values in the circumneutral range between 7 and 8.5 (Figure 4-3). Among the samples that had total Se concentration between 1 and $2 \mathrm{mg} / \mathrm{kg}, 75 \%$ had paste $\mathrm{pH}$ values between 7 and 8 . Concentrations of Se lower than $1 \mathrm{mg} / \mathrm{kg}$ were scattered over the entire paste $\mathrm{pH}$ range.

Total selenium and maximum potential acidity (MPA): Maximum potential acidity values ranged from 0.3 to 17 tons/1000 tons; less than $2 \%$ samples were outside that range (Figure 4-4a). There appeared no clear predictive relationship between these two parameters. MPA however showed a strong correlation with pyritic sulfur, the correlation coefficient being 0.99 (Figure 4-4b). Samples with pyritic sulfur value of greater than $0.50 \%$ had MPA values greater than 15 tons/1000 tons. 


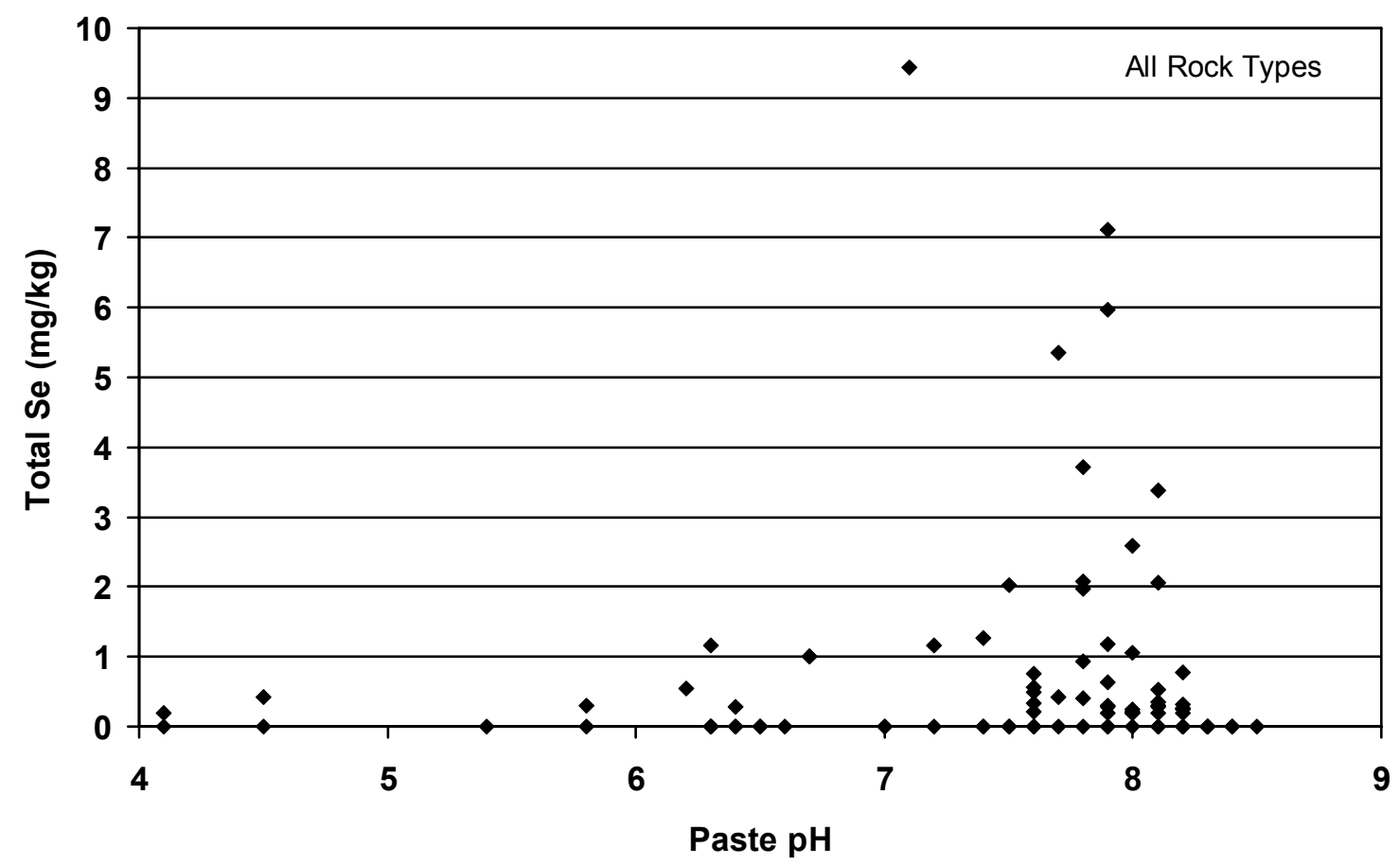

Figure 4-3 Plot of paste $\mathrm{pH}$ against total selenium. Samples with non-detectable selenium $(<0.20 \mathrm{mg} / \mathrm{kg})$ are graphed as $0 \mathrm{mg} / \mathrm{kg}$. 

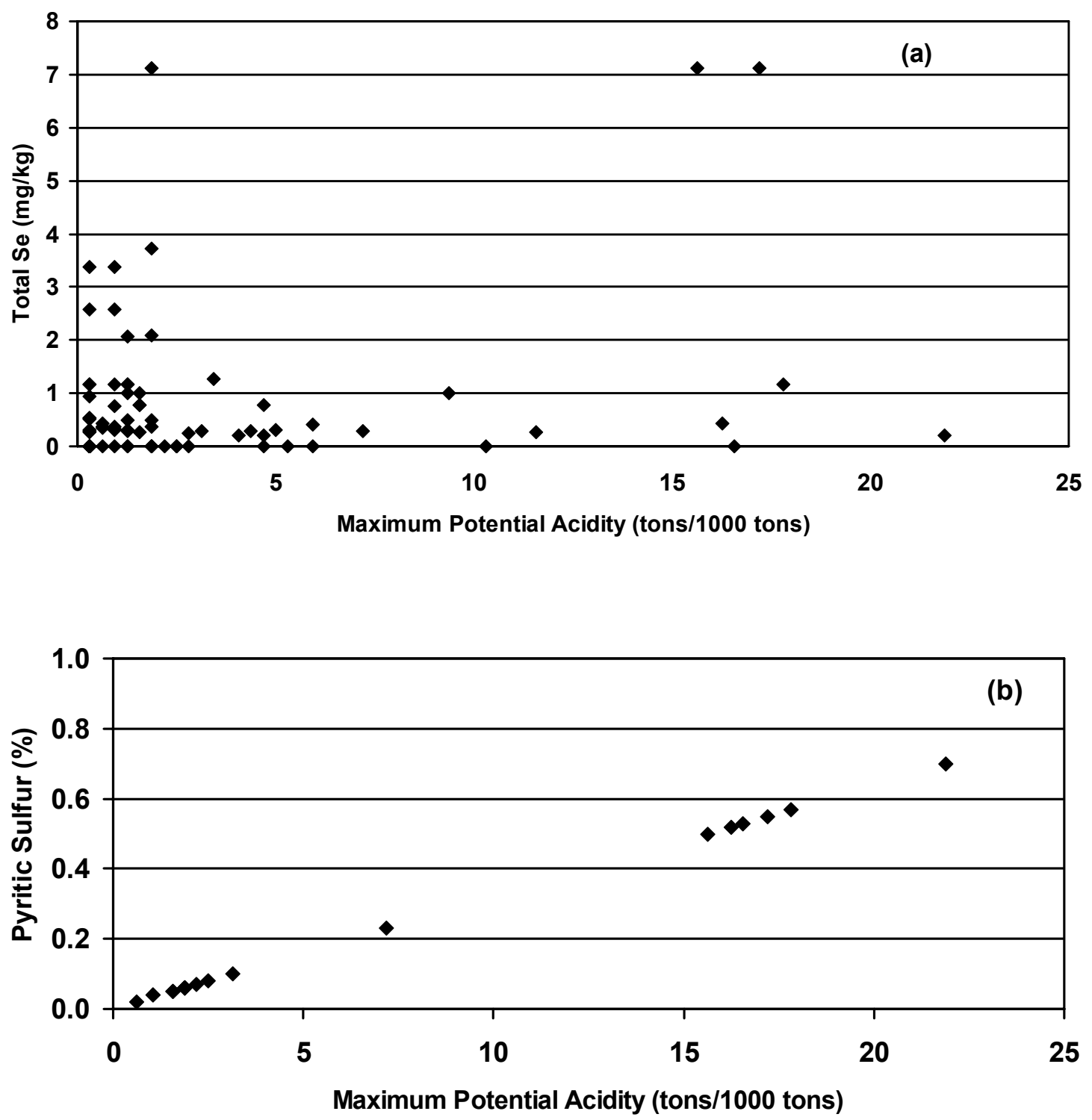

Figure 4-4 Relationship between MPA and total selenium. (a) Plot of MPA against total selenium for all samples. Samples with non-detectable selenium $(<0.20 \mathrm{mg} / \mathrm{kg})$ are graphed as $0 \mathrm{mg} / \mathrm{kg}$. One data value with MPA 84 tons/1000 tons not included in graph. (b) Plot of MPA against pyritic $S$. 
Total selenium and net neutralization potential (NNP): Net neutralization potential values for the rock core were obtained from the difference between the MPA and NP values. NNP values ranged from -96 to 82 tons/1000 tons. Of all these values $98 \%$ were in the range of -30 to 30 tons/1000 tons (Figure 4-5). Most of the samples with total Se greater than $2 \mathrm{mg} / \mathrm{kg}$ had a low value of NNP less than 10 tons/1000 tons or just slightly negative values. A neutral paste $\mathrm{pH}$ range indicated a balance of acidity and alkalinity parameters. Positive values of NNP indicated overall alkaline rock types (most NNP values being less than 10 tons/1000 tons).

Total selenium and total organic carbon (TOC): The concentration of total organic carbon in the rock core was as low as 100 to as high as $661,000 \mathrm{mg} / \mathrm{kg}$. A plot of TOC values against total Se values including all rock types (Figure 4-6a) showed no strong correlation between these two parameters. Individual plots for shales and coals against TOC showed that the TOC range for shales (Figure 4-6b) was much lower than that for coals (Figure 4-6c). But overall even for shales and coals there was no obvious relationship between TOC and total Se.

Total selenium and total sulfur $(\mathrm{S})$ : Total sulfur values for the rock core samples ranged from 0.01 to $1.80 \%$. A plot for S and total Se value showed that approximately $94 \%$ of the samples had total $\mathrm{S}$ values less than $1 \%$. There was no obvious relationship between total S and total Se concentration (Figure 4-7). The higher values for total S were from coal units. 


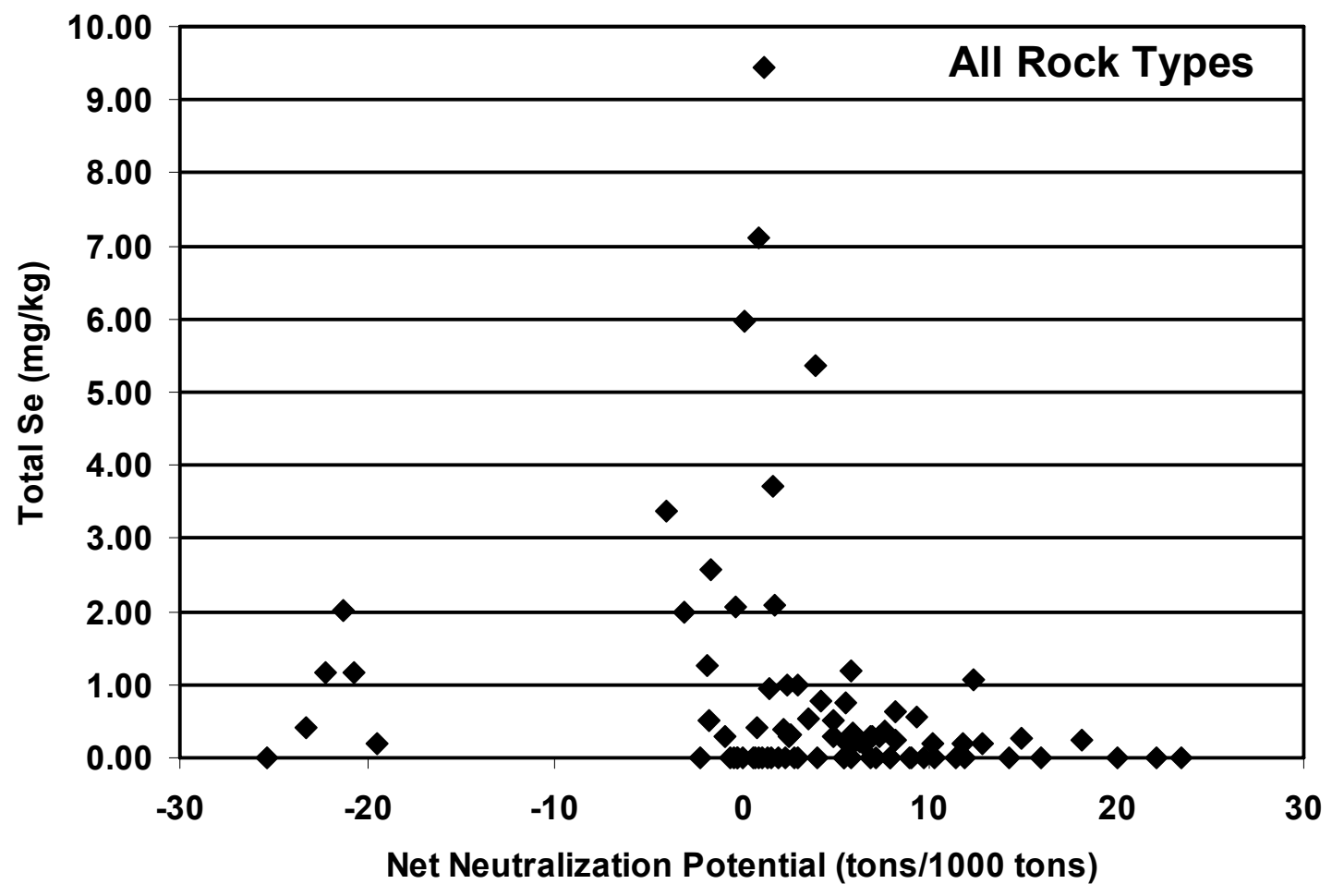

Figure 4-5 Plot of NNP against total selenium. Outliers with values of $\mathbf{- 9 6}$ tons/1000 tons and 82 tons/1000 tons are not included in graph. 

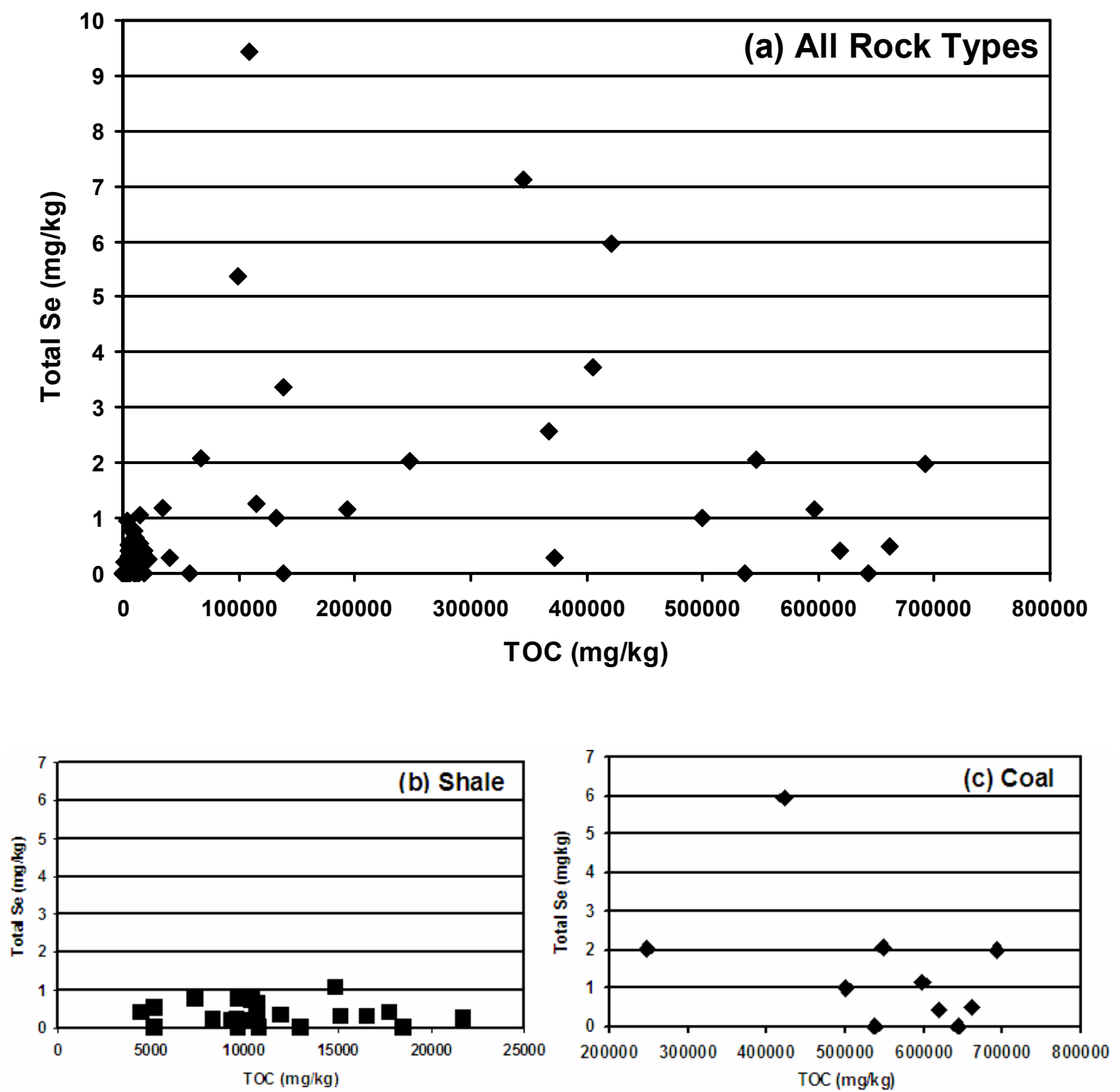

Figure 4-6 Plot of TOC against total selenium. (a) For all rock types. (b) For shale. (c) For coal. 


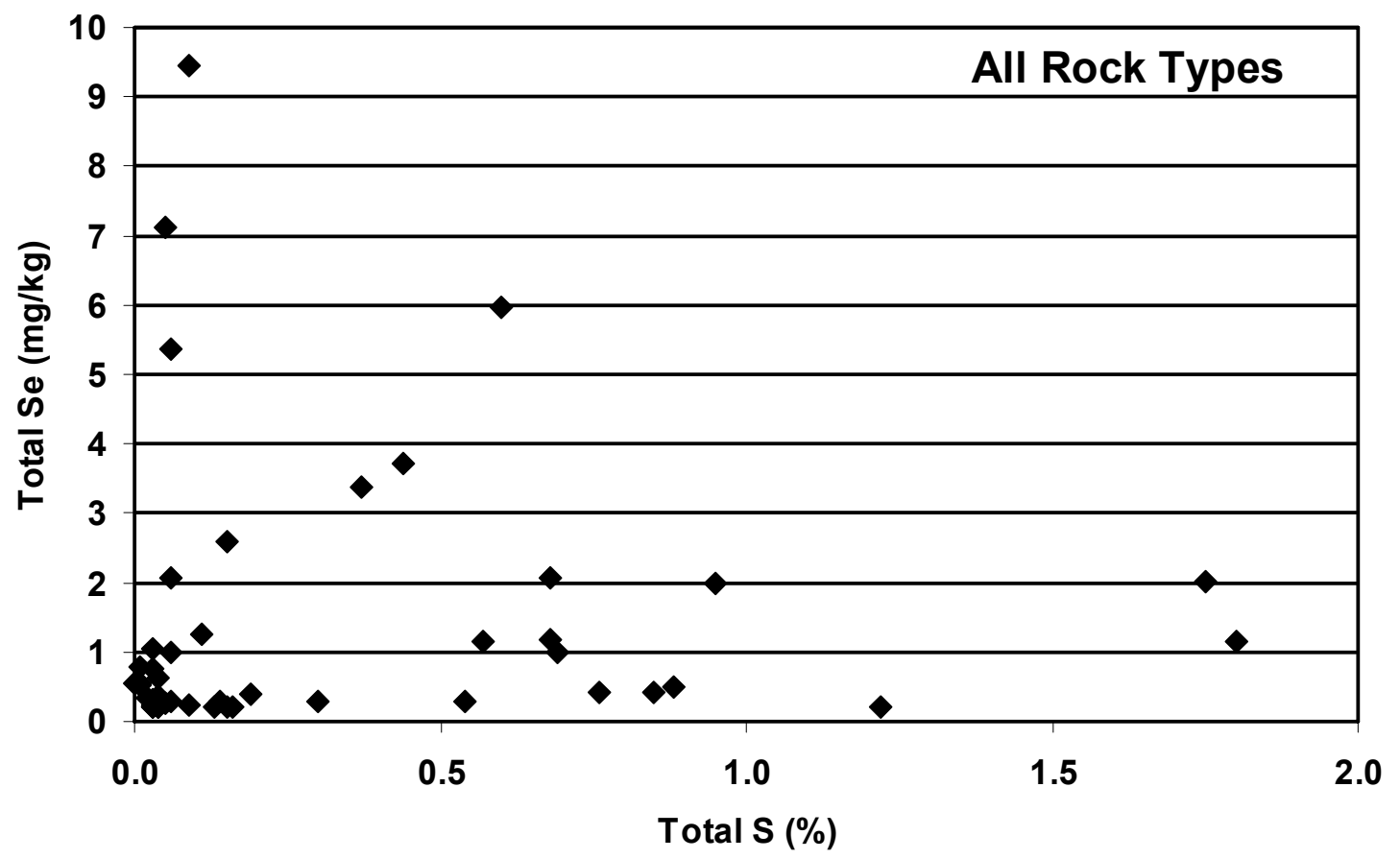

Figure 4-7 Plot of S against total selenium 


\subsection{Sequential extraction data}

\subsubsection{Distribution of data points}

The data from the sequential extraction are log-normally distributed. However, the geometric means and arithmetic means for the data match within $5 \%$ and thus the arithmetic means are used in the following assessment.

\subsubsection{Sum of extracted selenium data}

A comparison was done to see how much of the total Se was obtained through the sequential extraction procedure utilized. For this comparison, the normalized dry weight Se concentration for the extraction solutions were added along to the Se concentration in the residual fraction to obtain the sum of extracted Se. This was compared with the total bulk Se (Figure 4-8). The line with a slope of 1 indicates that all of the Se mass present was accounted for by the extraction methods. The extracted Se in the different fractions along with the residual solids matched well with the total Se from bulk analysis. Some deviations were noticed at higher Se concentrations above $3000 \mathrm{ug} / \mathrm{kg}$ where the summed value was slightly less than the total concentration. The deviation in most cases was less than $10 \%$. This loss of extracted Se (Table 4-1) might be due to mass loss at various stages of the extraction process. However, overall the good match of the data to the line indicates that little mass was lost during the extraction procedures.

Extraction of Se is largely a function of rock type (Figure 4-9). The mean extracted Se from coal, shale and mudstone was between 20 to $50 \%$. This value was determined by summing the mass of Se extracted and dividing it by the total Se measured in the bulk sample. The highest percentage of extracted Se was from shale where on average nearly 


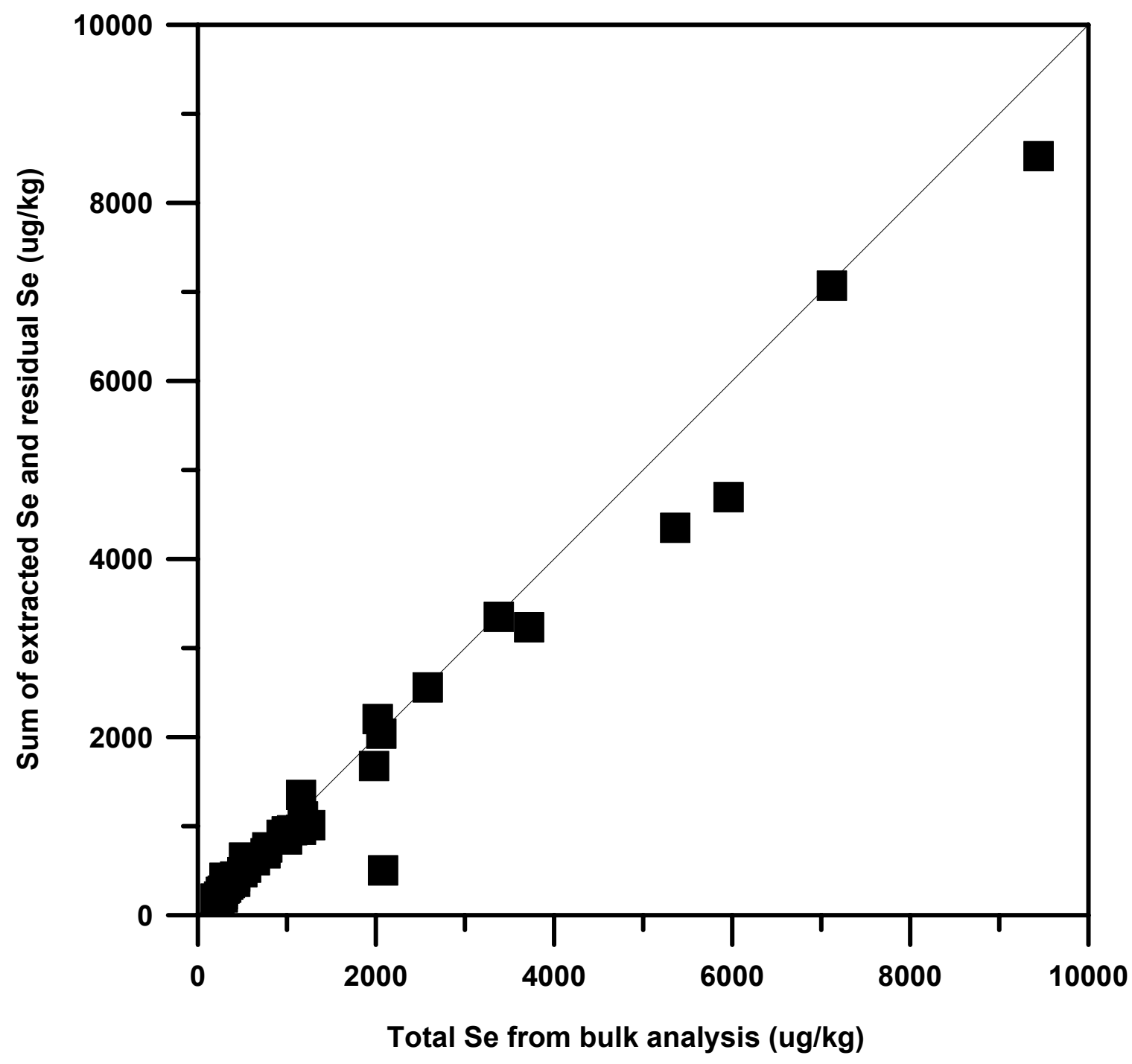

Figure 4-8 Comparison of total selenium measured in the bulk sample with the sum of the total selenium from the extraction steps and the residual fraction. The line has a slope of 1 . 


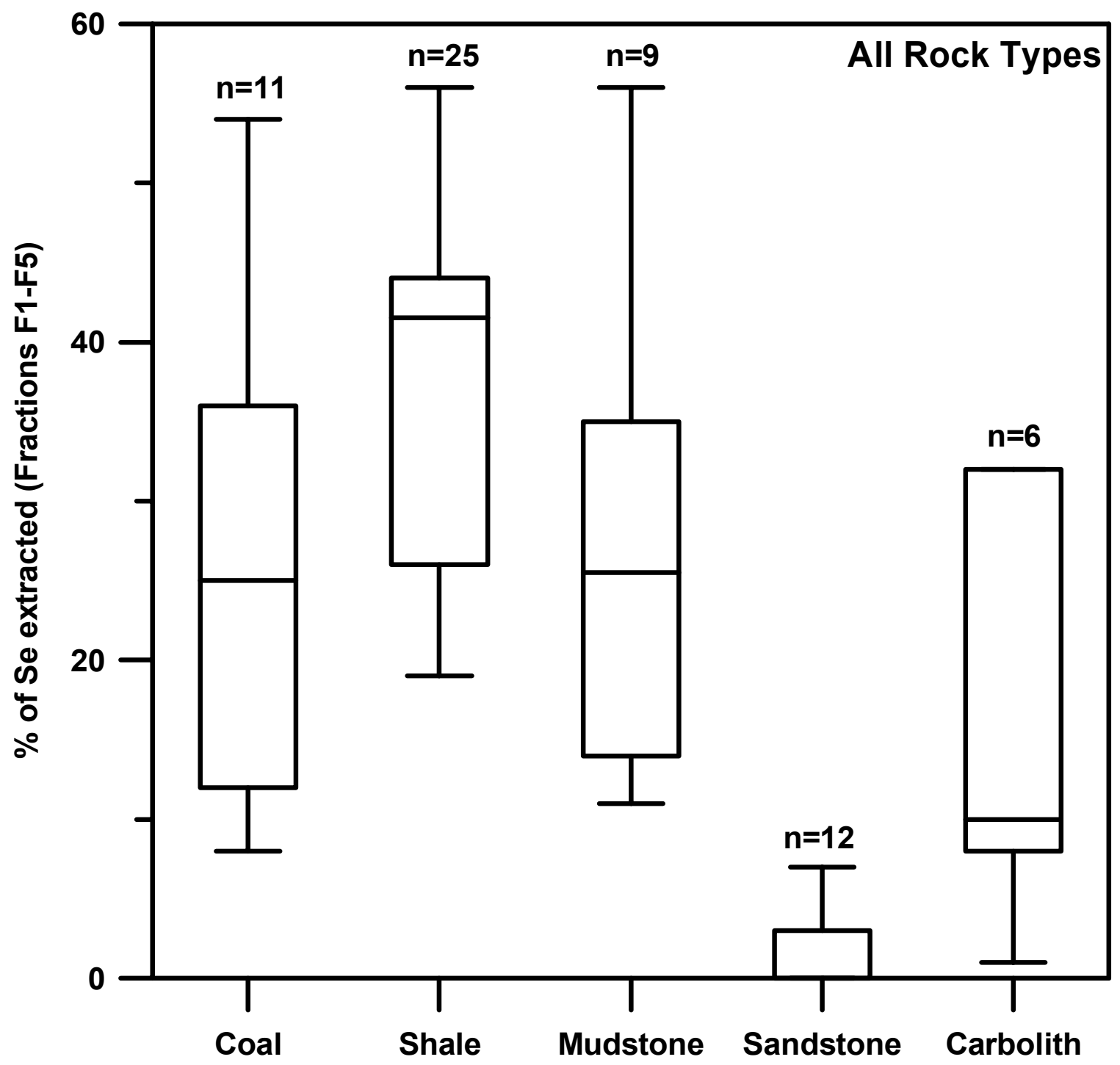

Figure 4-9 Comparative analysis of extracted selenium from different rocks. 
$40 \%$ of the total Se was extracted from the five different fractions. Overall it was seen that although shales had a lower mean value of total Se as compared to coal and carbolith rocks, a higher proportion of the Se could be extracted from them (Table 4-2).

Almost all samples of shale from which Se was extracted demonstrate total Se concentration lower than $1 \mathrm{mg} / \mathrm{kg}$ (Figure 4-10a). In coal, however, the percentage of extracted Se varied from $10 \%$ to more than $50 \%$. At least half of the coal samples having greater than $20 \%$ of extracted Se had total Se concentration greater than $1 \mathrm{mg} / \mathrm{kg}$. (Figure 4-10b). The amount of Se extracted in sandstones was the lowest.

\subsubsection{Calculation of selenium extracted from different fractions}

The amount of Se extracted from different fractions in the sequential extraction process varied by individual fractions as well as by different rock types (Figure 4-11 a-g). Most of the samples for the sequential extraction were chosen from below $80 \mathrm{ft}$ of depth. The upper regions of the Coalburg coal beds (above $80 \mathrm{ft}$ ) were primarily sandstone with total Se concentrations below the detection limit. There was a $1.4 \mathrm{ft}$ thick zone of mixed sandstone and coal at $81 \mathrm{ft}$ below ground surface, but the total Se concentration was still below the detection limit. From below $80 \mathrm{ft}$, the shales in the Coalburg coal bed had on average about $50 \%$ of Se extracted (Figure 4-11a-d). Shales in this bed had low total Se concentrations, average being $0.4 \mathrm{mg} / \mathrm{kg}$ (note changing $\mathrm{x}$-axis scale on figures). The percentage of extracted Se in shales increased with increasing depth in the Coalburg coal bed and where the shales were located close to the coal units. The coal units in the Coalburg coal beds had total Se concentration from below detection limit to as high as $3.72 \mathrm{mg} / \mathrm{kg}$. The highest Se extracted from a coal unit was $36 \%$ which was again from low total Se concentration of $0.42 \mathrm{mg} / \mathrm{kg}$. In the Coalburg coal beds organic Se generally dominated over other fractions (Appendix 1: Table A-4). 
Table 4-2 Comparison of total selenium and percent extraction in different rock types

\begin{tabular}{|c|c|c|c|c|c|c|c|}
\hline \multirow[t]{2}{*}{ Lithology } & \multirow[t]{2}{*}{$\mathbf{n}$} & \multicolumn{3}{|c|}{ Bulk total Se (mg/kg) } & \multicolumn{3}{|c|}{$\%$ of total extracted Se (F1-F5) } \\
\hline & & $\max _{(\mathrm{mg} / \mathrm{kg})}$ & $\min _{(\mathrm{mg} / \mathrm{kg})}$ & $\begin{array}{c}\text { mean } \\
(\mathrm{mg} / \mathrm{kg})\end{array}$ & $\begin{array}{c}\max \\
(\%)\end{array}$ & $\begin{array}{l}\min \\
(\%)\end{array}$ & $\begin{array}{c}\text { mean } \\
(\%)\end{array}$ \\
\hline Coal & 11 & 5.96 & $<0.20$ & 1.81 & 54 & 0 & 25 \\
\hline Shale & 25 & 5.36 & $<0.20$ & 0.85 & 56 & 0 & 40 \\
\hline Mudstone & 9 & 2.08 & 0.2 & 0.5 & 56 & 11 & 24 \\
\hline Sandstone & 12 & 0.96 & $<0.20$ & 0.13 & 7 & 0 & 1 \\
\hline Carbolith & 6 & 9.44 & 1.26 & 4.24 & 32 & 1 & 15 \\
\hline
\end{tabular}



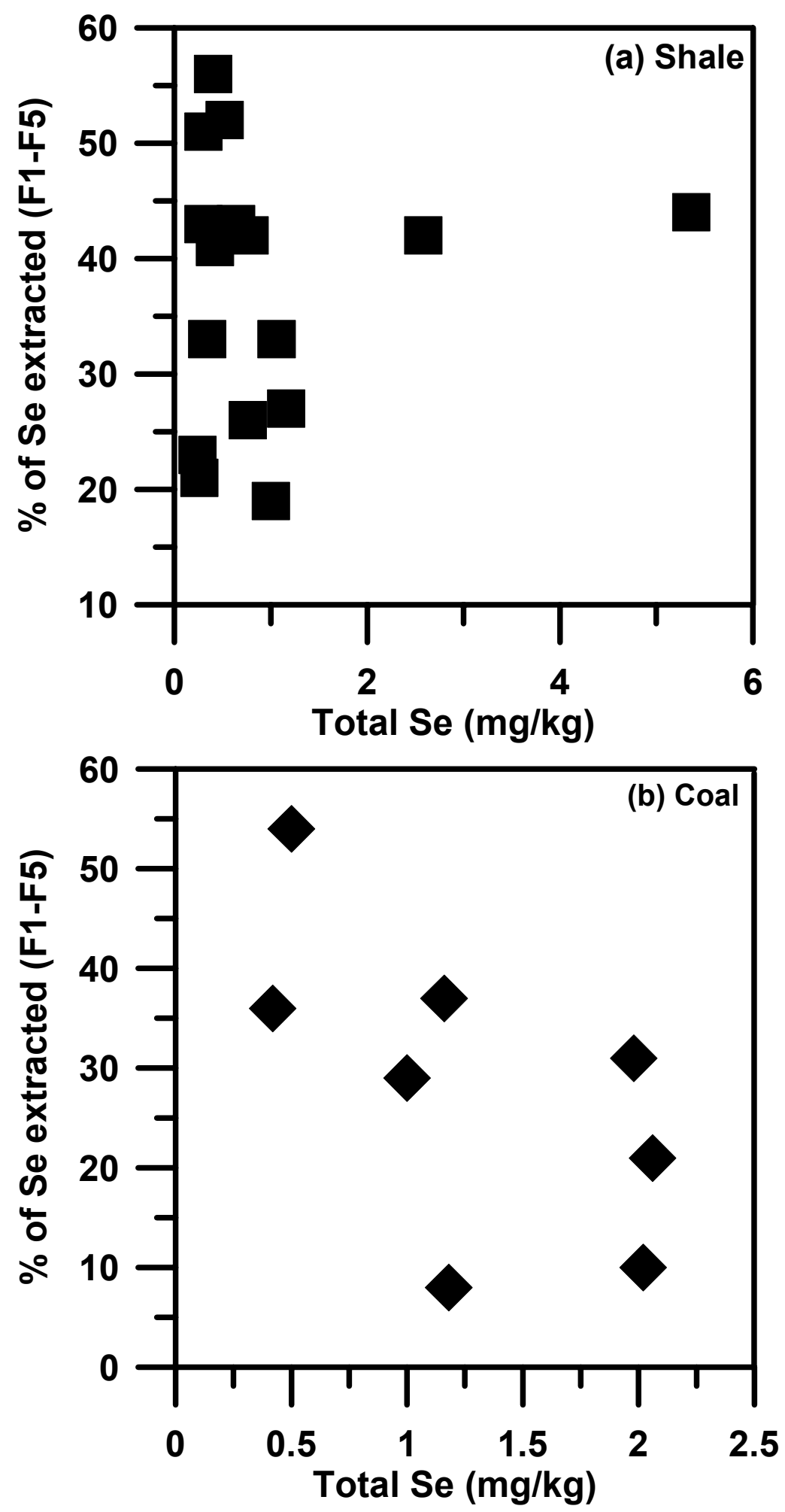

Figure 4-10 Percentage of selenium extracted vs. total selenium in (a) shale and (b) coal 
From the Winifrede rider coal beds, the average Se extracted was $30 \%$. The total Se concentration in shales was higher in this bed compared to the Coalburg bed, the average being $1 \mathrm{mg} / \mathrm{kg}$. Approximately $50 \%$ Se was extracted from a sample of shale with total Se concentration of $0.3 \mathrm{mg} / \mathrm{kg}$. Among the coal units, on average the highest extracted Se was from the Winifrede (Figure 4-11e-f). Mostly residual Se dominated followed by organic Se and sulfide Se (Appendix 1: Table A-4). Less Se was extracted in this coal bed than in the Coalburg on a percent basis; however, given the difference in total concentrations the mass extracted was more.

The Upper Winifrede coal bed had the highest total Se concentrations from all the coal beds studied in this research. From shales, about $40 \%$ of Se was extracted from samples that were within $2 \mathrm{ft}$ of coal units. Residual Se was dominant for shale samples followed by organic Se. For most coal units in this bed, $<10 \%$ of Se was extracted (Figure 4-11f). In Upper Winifrede coals, mostly residual Se was dominant followed by sulfide Se (Appendix 1: Table A-4).

From the Winifrede coal beds, a higher amount of Se was extracted from the shale units that were found within $2 \mathrm{ft}$ of the coal horizons. For mudstones too, samples that were within $2 \mathrm{ft}$ of the coal units had on average about $45 \%$ Se extracted from low total Se concentration. Otherwise mostly residual Se was dominant (Figure 4-11g).

In all the rock types there was no significant extraction of Se from the oxide fraction. Among the different rock types the minimum amount of Se was extracted from the sandstones. With the exception of two or three lithounits, the soluble fraction was not significant. Its presence in one sample suggests that it may be due to sample alteration. The samples were collected on March 2002 and ground prior to February 2005. 


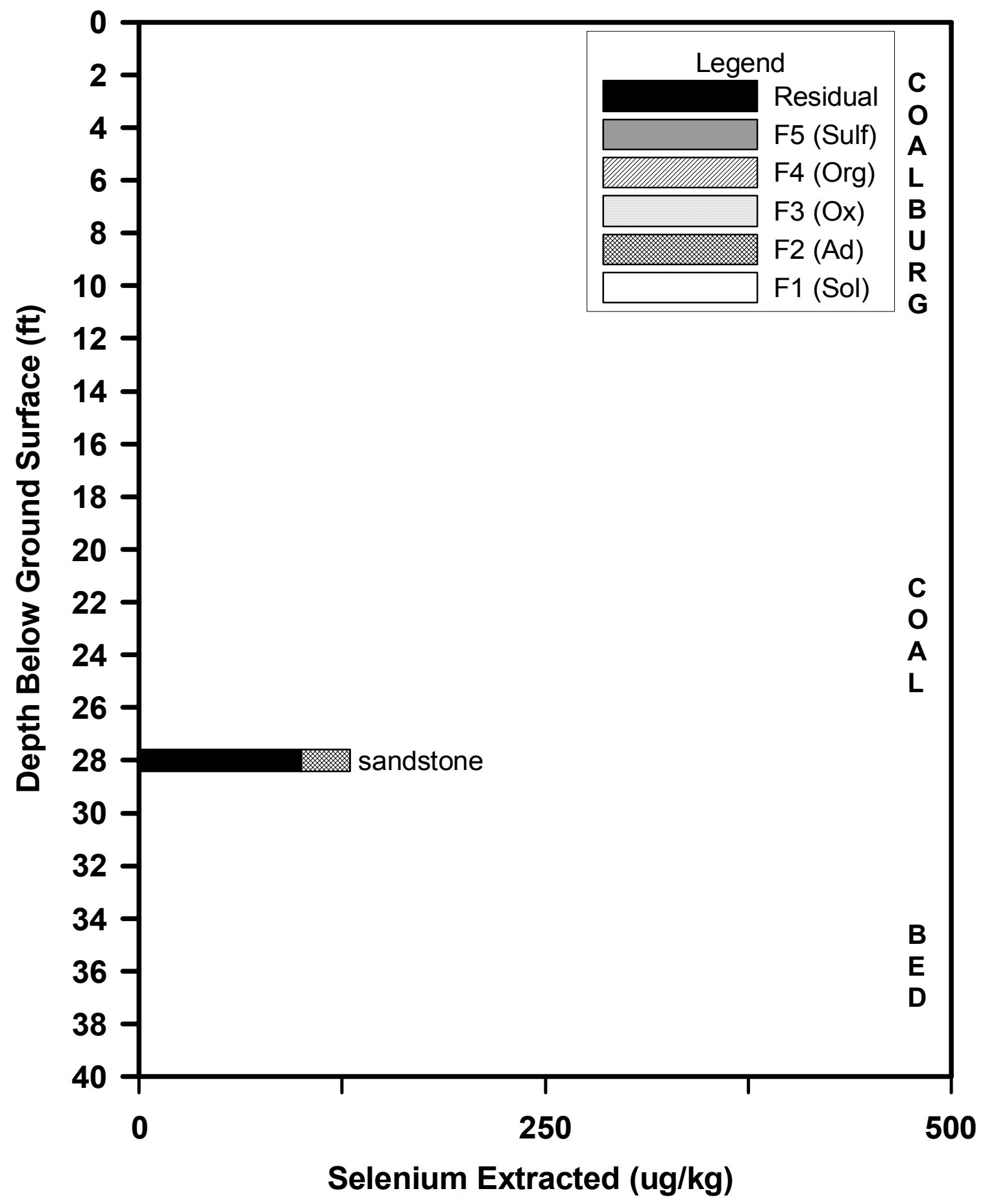

Figure 4-11a Extracted selenium by rock type. Depths: (a) 0-40 ft, (b) 40-80 ft, (c) 80-120 ft, (d) 120-160 ft, (e) 160-200 ft, (f) 200-240 ft, (g) 240$280 \mathrm{ft}$. (Note that scale of $x$-axis varies by figure to maximize the size of the bar charts and aid interpretation). 


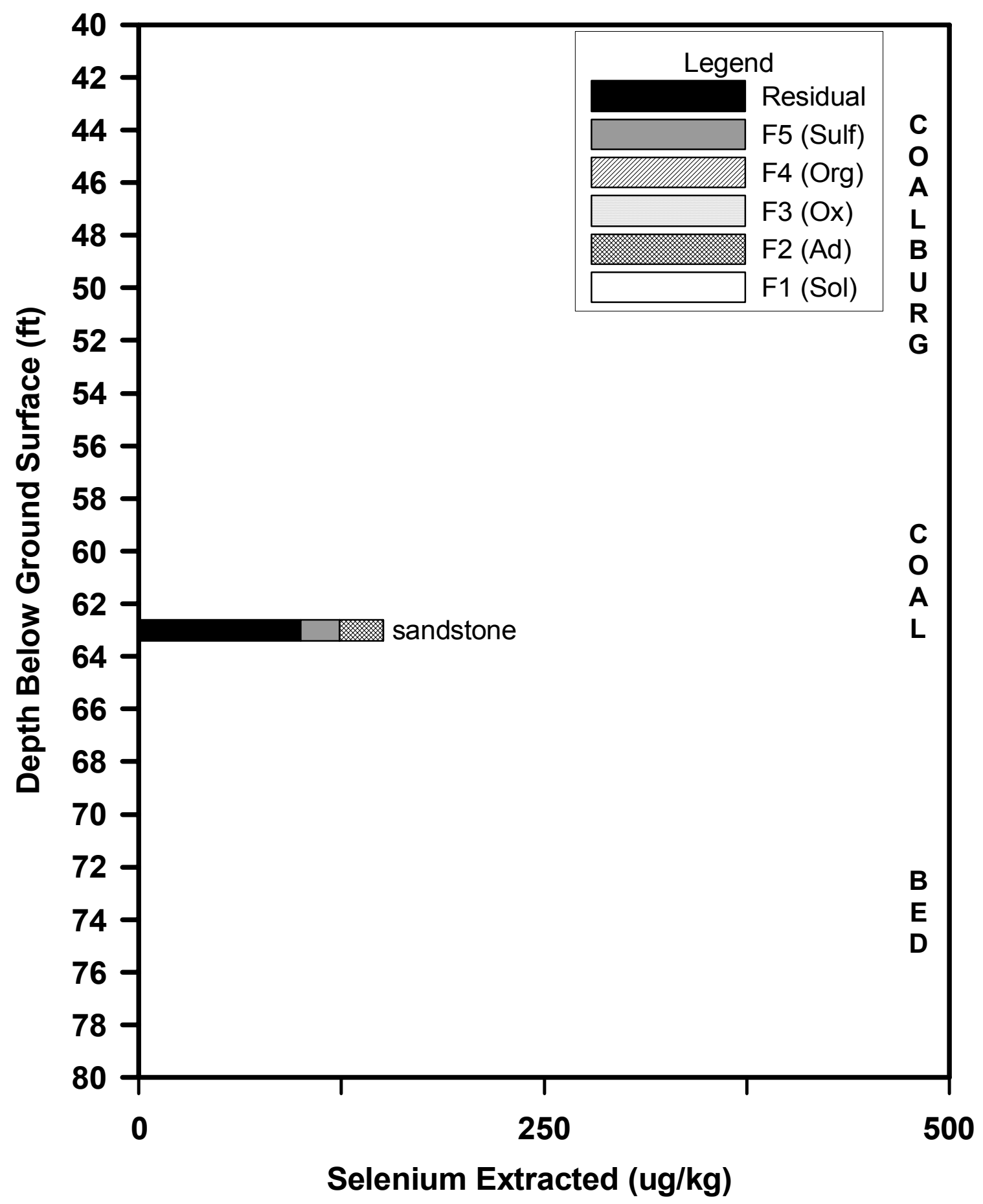

Figure 4-11b Extracted selenium by rock type. Depth: (a) 0-40 ft, (b) 40-80 ft, (c) 80-120 ft, (d) 120-160 ft, (e) 160-200 ft, (f) 200-240 ft, (g) 240$280 \mathrm{ft}$. (Note that scale of $\mathrm{x}$-axis varies by figure to maximize the size of the bar charts and aid interpretation). 


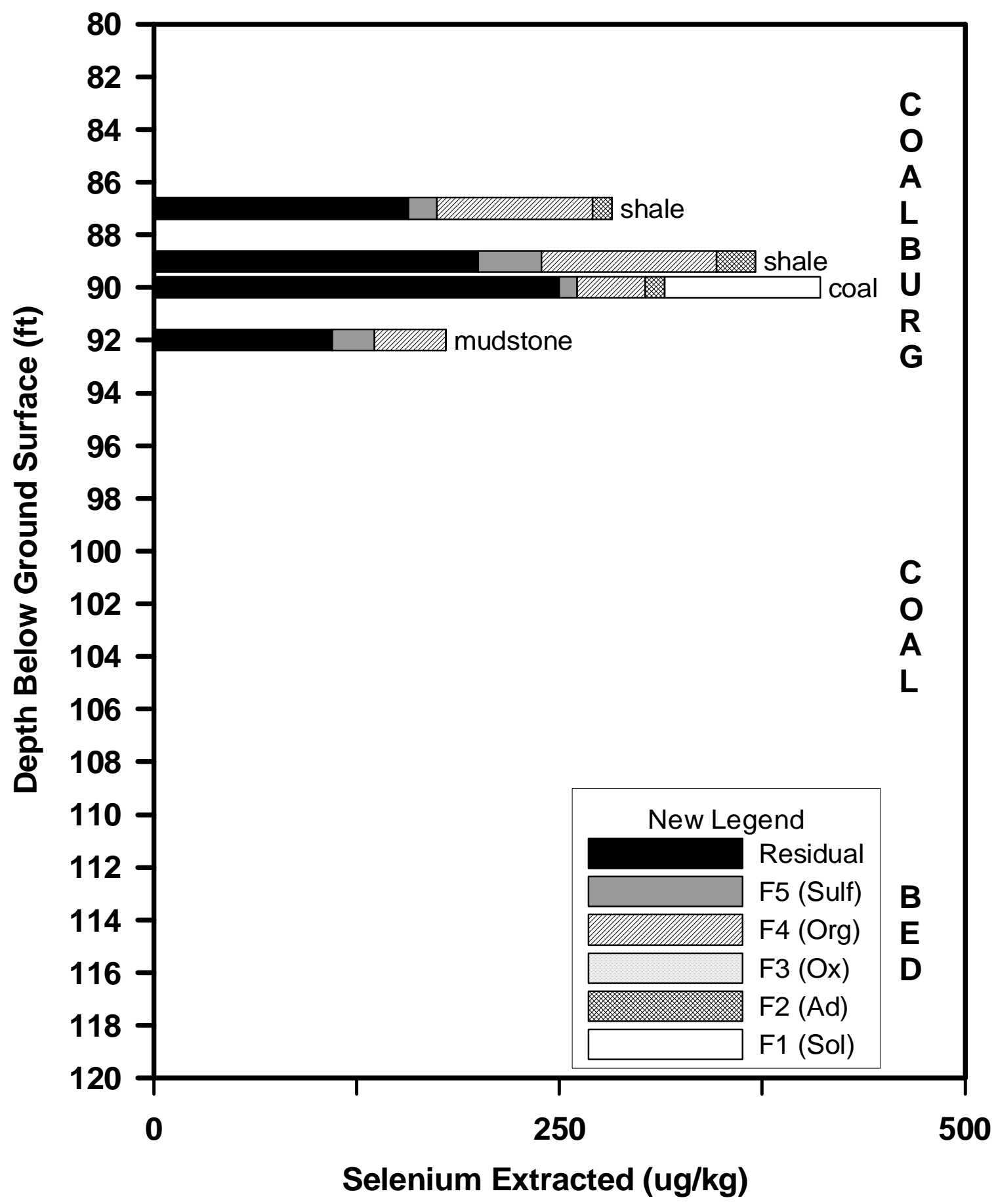

Figure 4-11c Extracted selenium by rock type. Depth: (a) 0-40 ft, (b) 40-80 ft, (c) 80-120 ft, (d) 120-160 ft, (e) 160-200 ft, (f) 200-240 ft, (g) 240-280 ft. (Note that scale of $x$-axis varies by figure to maximize the bar charts and aid interpretation). 


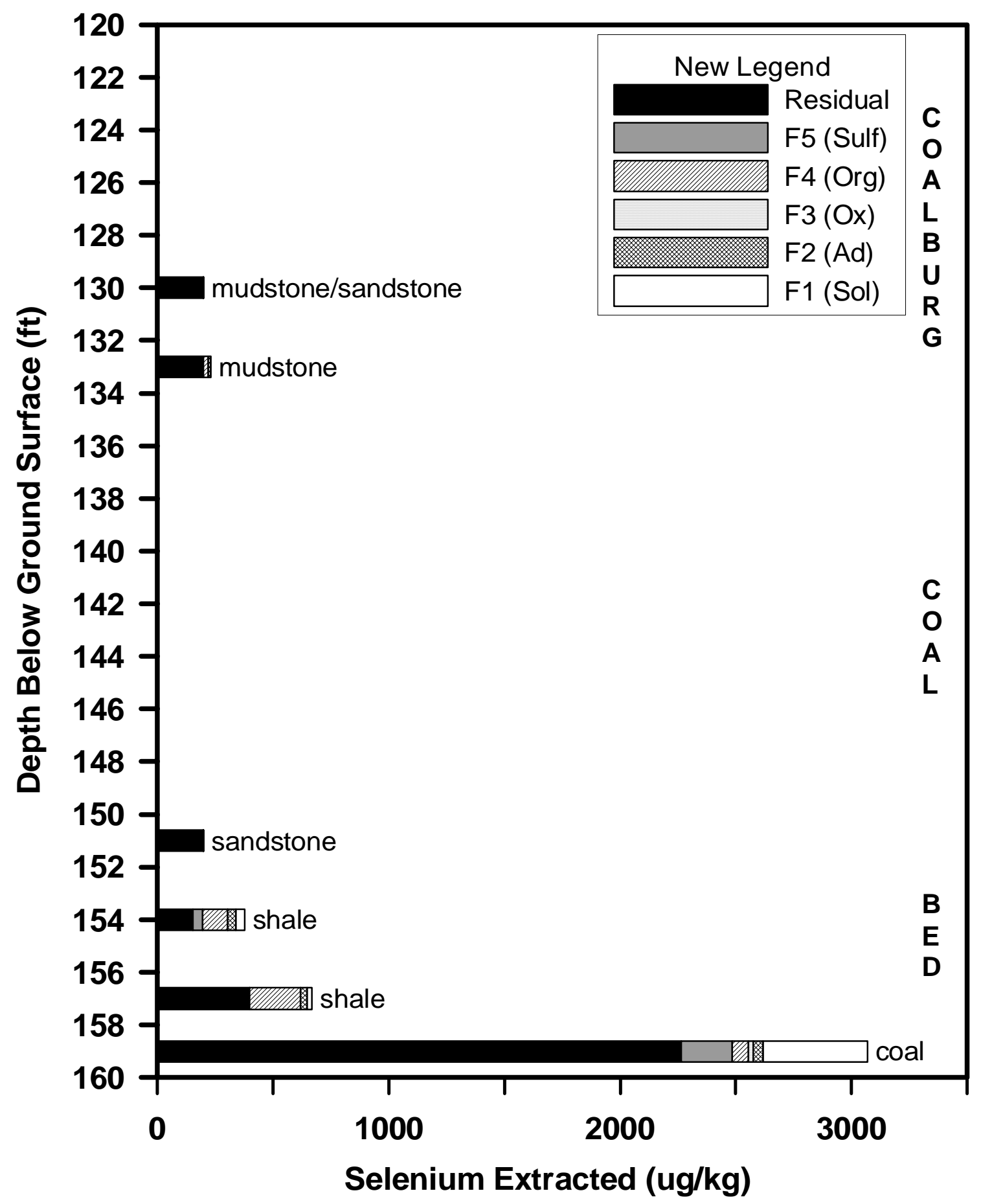

Figure 4-11d Extracted selenium by rock type. Depth: (a) 0-40 ft, (b) 40-80 ft, (c) 80-120 ft, (d) 120-160 ft, (e) 160-200 ft, (f) 200-240 ft, (g) 240-280 ft. (Note that scale of $x$-axis varies by figure to maximize the size of the bar charts and aid interpretation). 


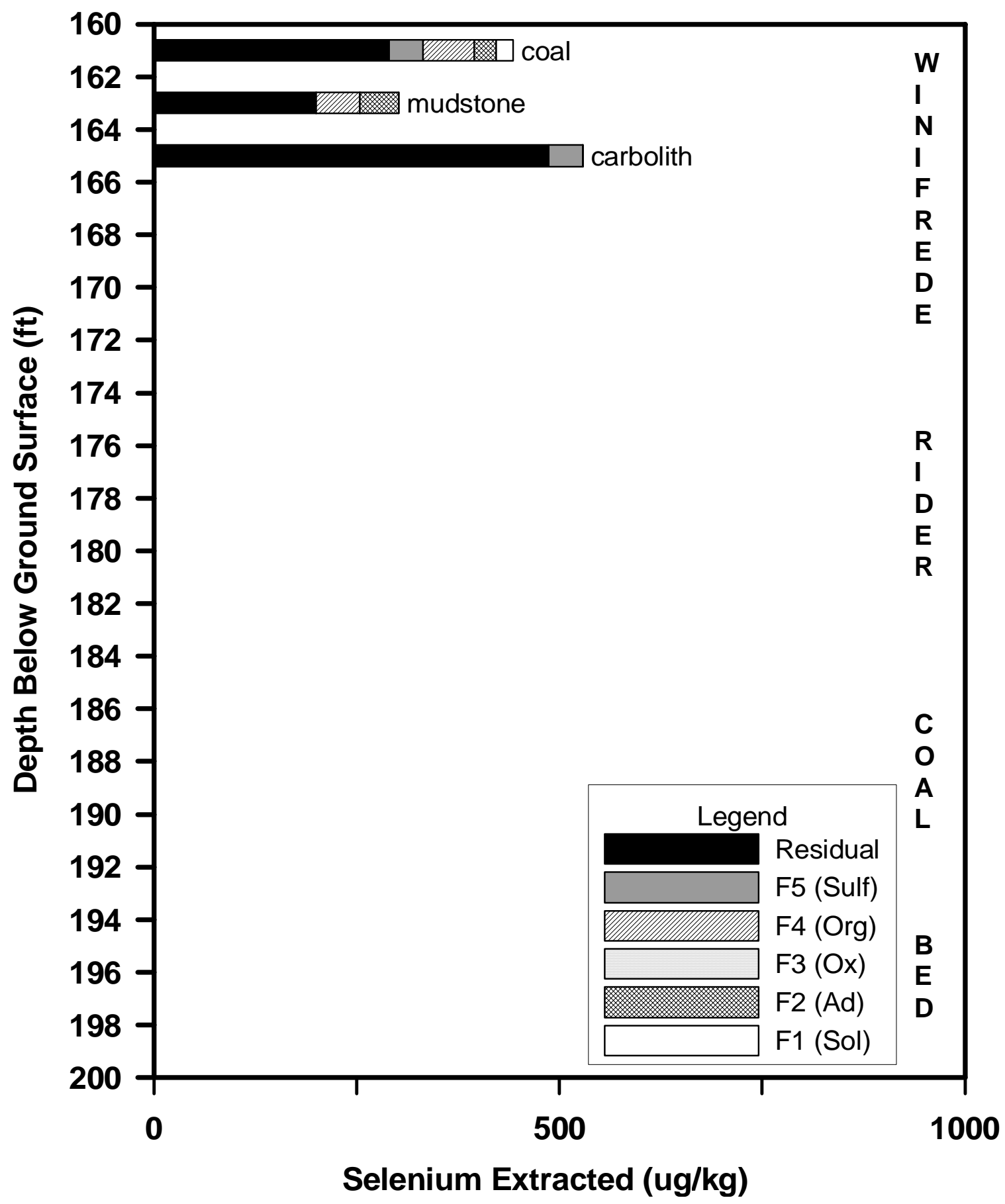

Figure 4-11e Extracted selenium by rock type. Depth: (a) 0-40 ft, (b) 40-80 ft, (c) 80-120 ft, (d) 120-160 ft, (e) 160-200 ft, (f) 200-240 ft, (g) 240$280 \mathrm{ft}$. (Note that scale of $x$-axis varies by figure to maximize the size of the bar charts and aid interpretation). 


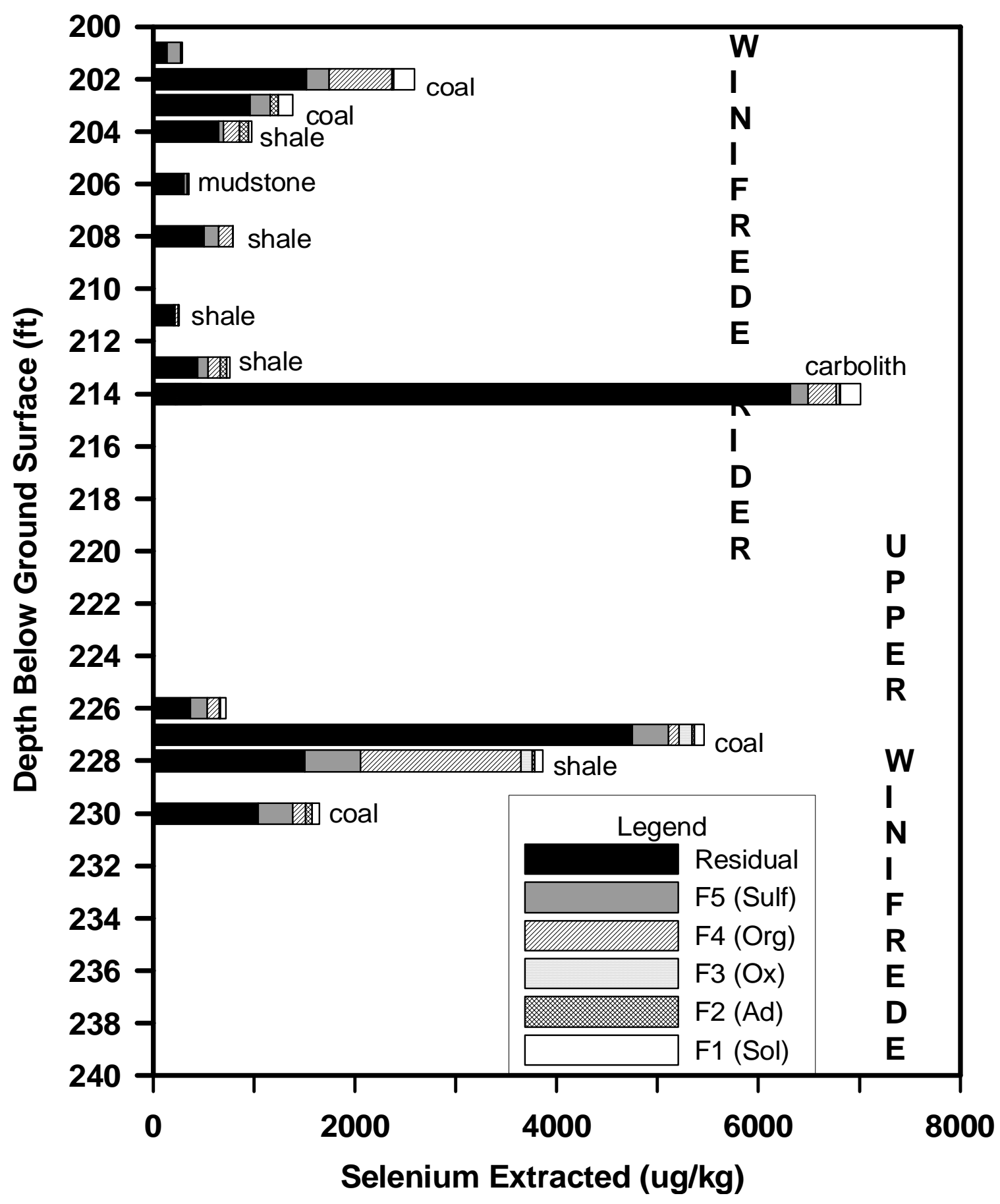

Figure 4-11f Extracted selenium by rock type. Depth: (a) 0-40 ft, (b) 40-80 ft, (c) 80-120 ft, (d) 120-160 ft, (e) 160-200 ft, (f) 200-240 ft, (g) 240-280 ft. (Note that scale of $x$-axis varies by figure to maximize the size of the bar charts and aid interpretation). 


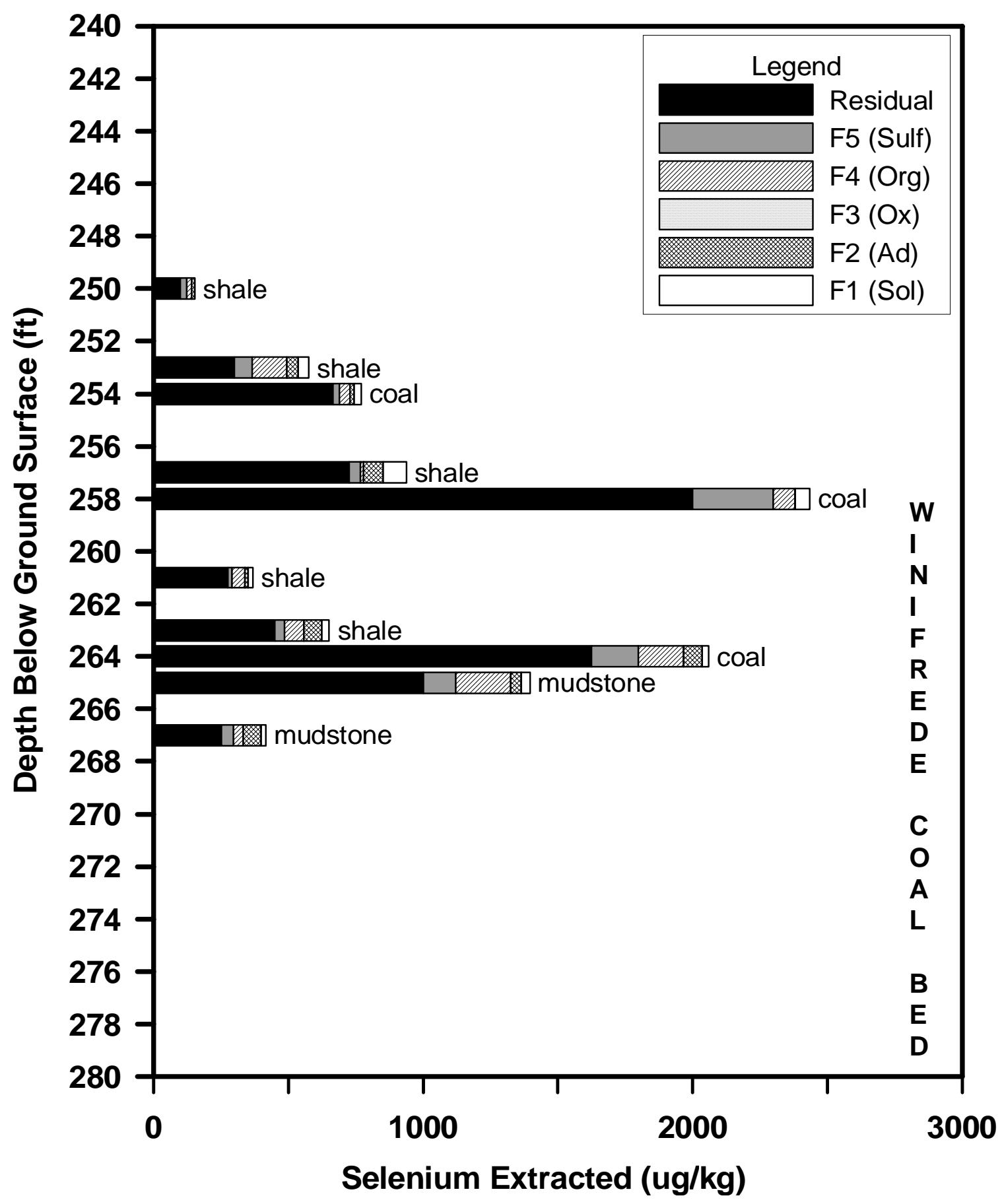

Figure 4-11g Extracted selenium by rock type. Depth: (a) 0-40 ft, (b) 40-80 ft, (c) 80-120 ft, (d) 120-160 ft, (e) 160-200 ft, (f) 200-240 ft, (g) 240-280 ft. (Note that scale of $x$-axis varies by figure to maximize the size of the bar charts and aid interpretation). 


\section{Chapter 5 Interpretation}

\subsection{Predicting total selenium concentration from stratigraphy and lithology}

The total Se content and hence its distribution in a rock core appears to depend on stratigraphy. Data from WVGES (2002a) report high total Se concentration for coal beds of the Kanawha Formation (Figure 2-4). According to the WVGES data, coals of the Kanawha and Allegheny Formations of the Pennsylvanian Period have the highest total Se concentration in West Virginia. These results indicate that Se enriched strata are not randomly distributed.

The studied core for the present research was from the Kanawha Formation and includes the Coalburg coal bed, the Winifrede rider coal bed, the Upper Winifrede coal bed and the Winifrede coal bed. Less total Se was associated with the Coalburg coal bed than in the lower beds. The sandstone lithology within the Coalburg bed mostly had total Se below the detection limit of $0.20 \mathrm{mg} / \mathrm{kg}$. Shale and mudstone outcrops within the Coalburg had total Se concentration below $1 \mathrm{mg} / \mathrm{kg}$. Similar observations were found for the sandstones within the Winifrede rider; shales within this zone had higher total Se concentration than shales in the Coalburg. With increasing depths in the Upper Winifrede and Winifrede Coal beds, shale and coal units became dominant with higher total Se concentration. Sandstone units in other coal beds also mostly had total Se concentration below the detection limit.

Data from this study indicate that Se can be found in specific zones in relation to the coal units. Lithologic units located less than $2 \mathrm{ft}$ from the coal unit had higher Se concentrations than units which were more than $2 \mathrm{ft}$ away from the coal units (Figure 51). These $2 \mathrm{ft}$ zones were calculated from the top of the coal units to the bottom of the overlying rock units, or from the bottom of the coal unit to the top of the underlying units. The less than $2 \mathrm{ft}$ zones or the “coal proximate layers” had on average about 7 
times more Se present. Lithologic units which were more than $5 \mathrm{ft}$ away from the coal bed had very low total Se concentrations. The coal proximate layers correspond to the “toxic units” defined by Renton et al. (1989). The coal proximate relationship holds true for all rocks, but is particularly true for shale (Figure 5-2). Shales had higher Se concentrations than other rock types such as mudstone and sandstone; and the shale concentration increased if the shale occurred near to a coal unit. Shale situated less than $2 \mathrm{ft}$ from a coal unit had a mean Se concentration 8 times higher compared to a shale horizon situated more than $2 \mathrm{ft}$ away from a coal unit. Similar findings by Mullennex (2005) interpret that higher Se concentration for shales which are near to the coal beds are due to plant material accumulation and corresponding depositional environment. Mullennex’s data include the No. 6 Block coal and the No. 5 Block coal of the Allegheny Formation and the Stockton and Coalburg coal beds of the Kanawha Formation. The consistency between the data in this study and that reported by Mullennex suggest this relationship is not spatially limited.

\subsection{Predicting total selenium concentration in rock cores from other chemical parameters}

One potential predictor for total Se concentration in rock cores was the neutrally characteristic paste $\mathrm{pH}$ range and the NNP obtained from ABA. Lithologic units having

$\mathrm{pH}$ in the neutral range did not necessarily contain Se, but almost all rocks that have high Se concentration were in circum-neutral zones of $\mathrm{pH}$. For the studied rock core, almost all of the samples had a positive NNP thus indicating a dominance of alkaline rock types for those samples, a condition that results from a reduced amount of leaching (Rose and Cravotta 1998). 


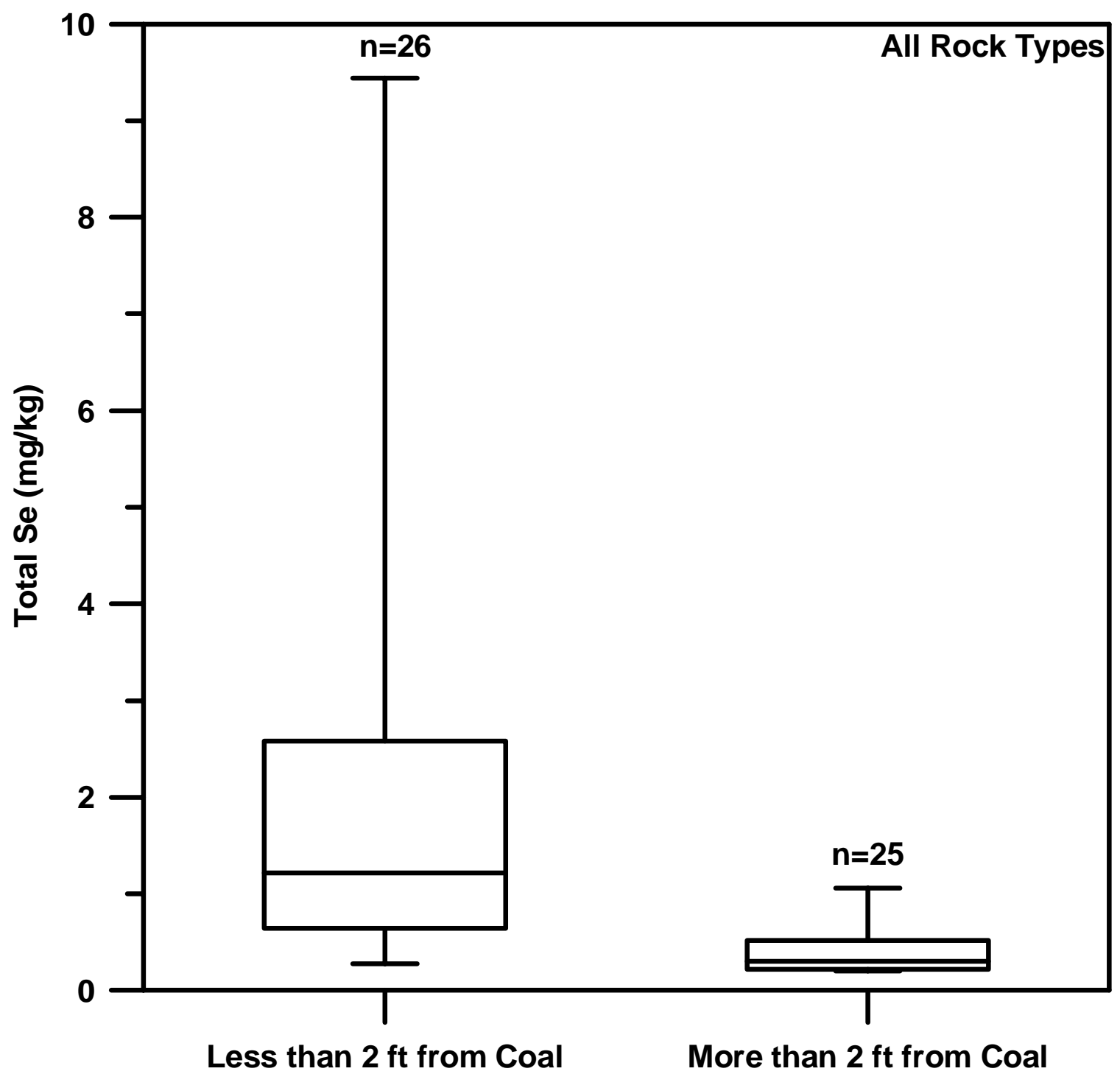

Figure 5-1 Comparison of selenium concentration from all rocks situated less than $\mathbf{2} \mathbf{f t}$ from coal horizons with that of rocks situated more than $\mathbf{2} \mathbf{f t}$ from coal horizons. Non-detectable selenium values $(<0.20 \mathrm{mg} / \mathrm{kg})$ are not included in graph. 


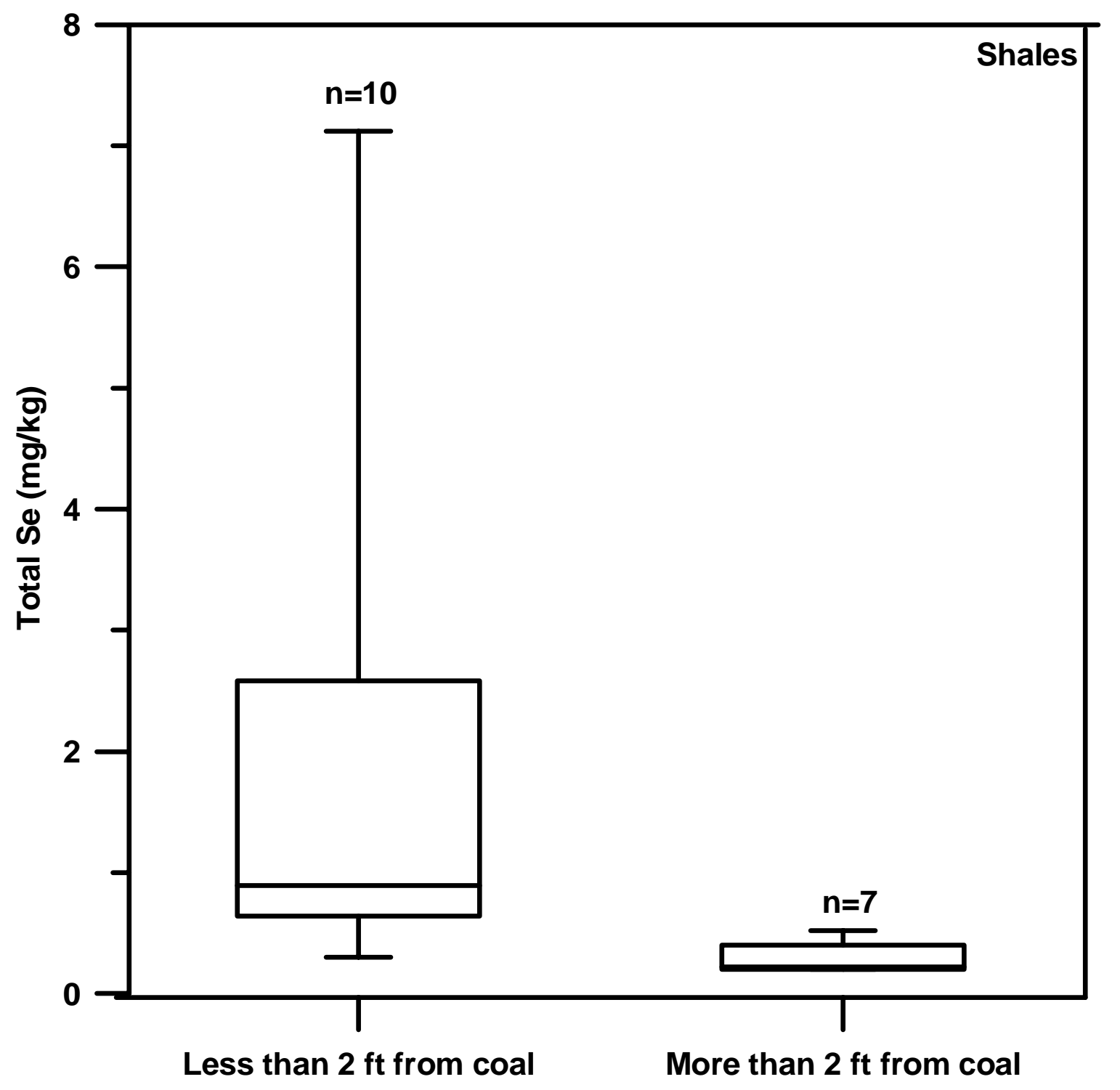

Figure 5-2 Comparison of selenium concentration for shales situated more or less than $2 \mathrm{ft}$ from coal beds. Non-detectable selenium values $(<0.20$ $\mathrm{mg} / \mathrm{kg}$ ) are not included in graph. 
In this study no correlation was observed between Se and TOC. However in case of rock types like coal TOC values were much higher than in other rock types like shale (Figure 4-6). This might suggest that organic Se associations might be preferable in coals.

In spite of sulfides being important Se bearing minerals, no direct correlation was observed between Se and total S concentrations for this study. Of all the rock types, high S values above $0.50 \%$ were particularly noticed in coal bearing horizons (Figure 4-7). The Coalburg horizon had the highest value of total S for a coal sample but had a total Se concentration below the detection limit. The $\mathrm{S}$ fractionation data for coal indicates that most of the S was organically bound (Table 5-1) which might account for preference of organic associations for coal. Mullenex (2005) also reported no positive correlation between total Se and S concentrations. According to his findings high values of total S were found in Coalburg coal horizons and did not correlate significantly with total Se concentration. According to Coleman et al., (1993) no correlation was observed between Se concentration and S concentration for eastern coals. The data from this study, Mullennex, and Coleman et al. collectively support the conclusion that $\mathrm{S}$ concentration is not a good predictor of Se concentration in the eastern coal beds.

\subsection{Predicting relative extraction of selenium from different rock types}

The amount of Se extracted from different fractions of a rock was determined by the sequential extraction methods and hence provides "relative" extraction predictions. The amount of Se extracted from different rock types varied from less than $1 \%$ to more than $50 \%$. Of all the rock types, sandstones had the least amount of extracted Se concentration on both mass and percent basis. This is justified by the fact that in most cases the total Se concentration in sandstones was below the detection limit. 
Table 5-1 Total sulfur, organic sulfur, and selenium parameters for coal

\begin{tabular}{|c|c|c|c|c|}
\hline $\begin{array}{l}\text { total Se } \\
(\mathrm{mg} / \mathrm{kg})\end{array}$ & $\begin{array}{c}\text { extracted } \\
\text { Se } \\
(\%)\end{array}$ & $\begin{array}{l}\text { total S } \\
\text { (\%) }\end{array}$ & $\begin{array}{c}\text { organic S } \\
\text { (\%) }\end{array}$ & $\begin{array}{c}\text { organic } \% \text { of total S } \\
\text { (\%) }\end{array}$ \\
\hline$<0.2$ & 0 & 6.2 & 2.6 & 42.6 \\
\hline 3.7 & 22 & 0.4 & 0.4 & 81.8 \\
\hline 0.4 & 36 & 0.8 & 0.7 & 89.4 \\
\hline 1.2 & 37 & 1.8 & 1.1 & 63.3 \\
\hline 1.0 & 29 & 0.7 & 0.5 & 71.0 \\
\hline 0.5 & 21 & 0.9 & 0.7 & 85.2 \\
\hline 5.9 & 12 & 0.6 & 0.5 & 76.7 \\
\hline 1.9 & 54 & 0.9 & 0.8 & 86.3 \\
\hline$<0.2$ & 0 & 0.7 & 0.6 & 92.6 \\
\hline 2.0 & 10 & 1.7 & 0.7 & 42.9 \\
\hline 2.0 & 31 & 0.7 & 0.6 & 92.6 \\
\hline
\end{tabular}


Mudstone samples that are found within $2 \mathrm{ft}$ of the coal units had a higher percentage Se extracted than other mudstone units. Fewer carbolith and mudstone samples were available for this research than coal and shale samples.

Average extracted Se concentration was higher for shale units than for coal units on a percent basis. In shales on average $40 \%$ of Se was extracted compared to $25 \%$ extraction for coal. These data suggest that the relative extraction of Se tends to be higher from shales than it does from coals. In shales the mass of extracted Se had a strong relationship with respect to its position from the coal unit. Shales placed within 2 $\mathrm{ft}$ of the coal unit were more prone to extraction of Se than other shale units (Figure 5-3). Thus shale overburden units had a higher mass of Se extracted and this extraction was independent of the total Se concentration. Thus even shales with a low concentration of total Se may be sensitive to extraction if they are located within $2 \mathrm{ft}$ of the coal units.

The average extracted Se from coal units was $25 \%$. Although it has been seen that the total Se concentration is independent of the total S concentration for coals, there might be some interdependence between extracted Se and total S concentration. All coals that had more than $20 \%$ of Se extracted have total S concentration lower than $0.9 \%$ (Figure 5-4). Higher amount of Se is extracted from coals that on an average had organic $S$ concentration more than $80 \%$ (Table 5-1). However, no statistically significant correlation exists between Se concentrations (both bulk and extracted) with total S, organic S, and pyritic S. 


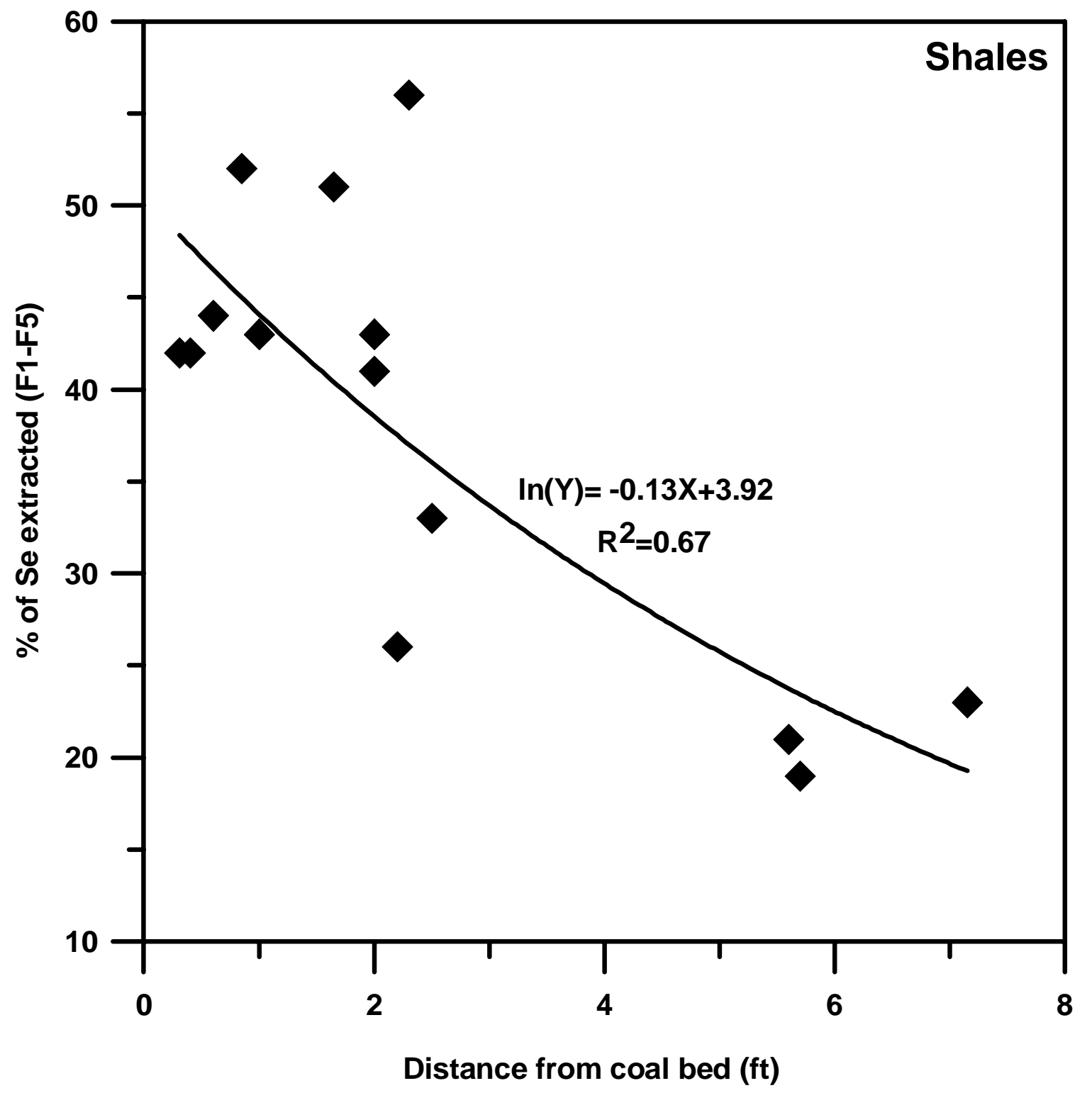

Figure 5-3 Relationship between extracted selenium and distance from coal bed for shales. 


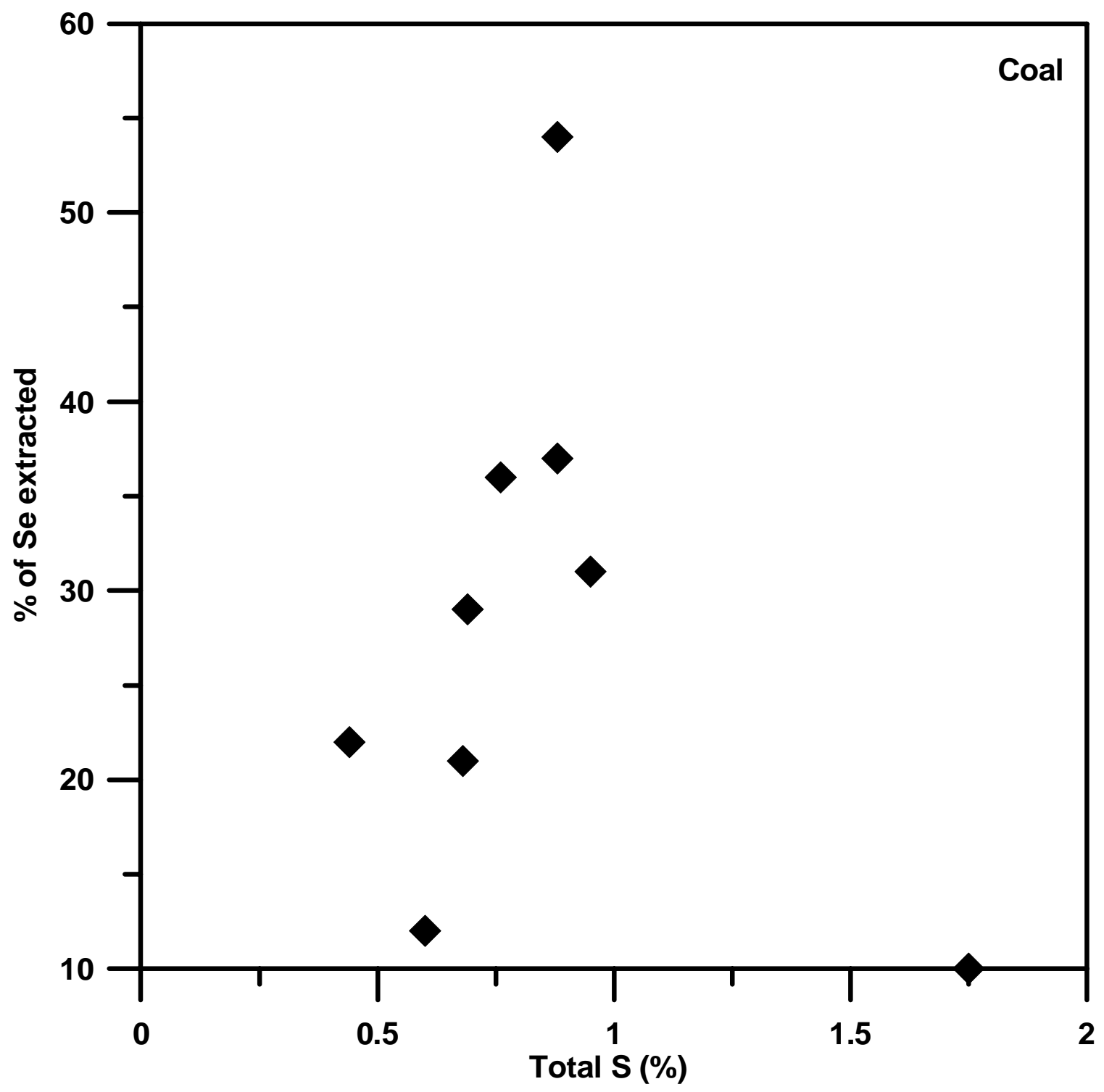

Figure 5-4 Plot of total S against sum of extracted selenium for coal. Samples having extracted selenium below the detection limit ( $<0.20 \mathrm{mg} / \mathrm{kg})$ are not included in graph. 


\subsection{Mode of occurrence of selenium in different rock fractions}

The mass of Se extracted from different fractions varied from one rock type to another. These data can be useful in predicting the mode of occurrence of Se in different lithologies. From the distribution of Se extracted in different fractions of shale it was apparent that in most samples approximately $45 \%$ of the extracted Se was extracted from the organic fraction alone (Figure 5-5a). In some cases the extraction from the organic fraction was up to $80 \%$. Thus the Se residing within the organic fraction of shale was most susceptible to extraction compared to the other fractions. Se extracted from the sulfide fraction in shales approximately account for about $25 \%$ of the total mass of extracted Se (Figure 5-5b). The remaining mass of extracted Se in shale accounts for extraction from the soluble and adsorbed phases, the extraction from the oxide fraction being negligible.

In coal, Se extracted from the sulfide fraction was dominant over the other fractions. A distribution of the percentage of total Se extracted against the percentage of Se extracted only from the sulfide fraction shows that on an average, about $40 \%$ of Se was extracted only from the sulfide fraction (Figure 5-6a). After the sulfide fraction the organic fraction played the next important role in coals. On an average about $20 \%$ of the mass of extracted Se came from the organic fraction in coal (Figure 5-6b). Thus the sulfide and to some extent the organic fractions were the dominant phases from where Se can be extracted out in coals. The remaining $40 \%$ of the extracted Se in coals came from the soluble and adsorbed phases, the extracted Se from the oxide fraction being negligible. Thus for coals, although the organic associations were favorable for them, not much Se was extracted from the organic fraction. This might suggest that the Se is bound strongly to the organic fraction in coal and are not easily released. However, degree of extraction was likely to be an overestimation from natural geochemical settings since extraction conditions and reagents are not found in the natural environment. 
For other rock types like mudstone and carbolith, there were insufficient samples for interpretation. These samples were however included to see if overall any relationships exist. Mudstones that were found in the coal proximate layers had higher percentage Se extracted from them. Mudstone samples within $2 \mathrm{ft}$ of the coal beds on an average had about $45 \%$ of Se extracted only from the organic fractions. Thus for mudstones Se residing in organic fractions can account for a high amount of extraction. Sandstones had the lowest amount of Se extracted from the different fractions which was again due to total Se concentration in sandstones being below the detection limit of the analytical method for most cases.

\subsection{Limitations of the research}

This research was focused on a single rock core which might not be representative on a bigger scale. However, many of the conclusions made in this study, particularly related to the distribution of Se in coal proximate layers, agree well with recent work by Ron Mullennex (2005) suggesting that this interpretation is not limited to the one core.

The sequential extraction was an operationally defined process and therefore the designation of the fractions conceptually, and separation of Se into fractions, should be reviewed within limits. However, based on several literature surveys, the particular method adopted for this research seemed to work well with all the sequentially extracted fractions. Our extracted sulfate data suggest that the separation of Se into organic and sulfide bound forms was reasonable. In this process the F5 (sulfide) fraction had the highest S content with the F4 (organic) fractions having the lowest S concentration.

All the samples for this research were ground to the same size, although the final size distribution was not measured. Thus, parameters like surface area and sample size were not included for the overall interpretation. Consideration of these factors and changing these factors might have an effect on the results. 

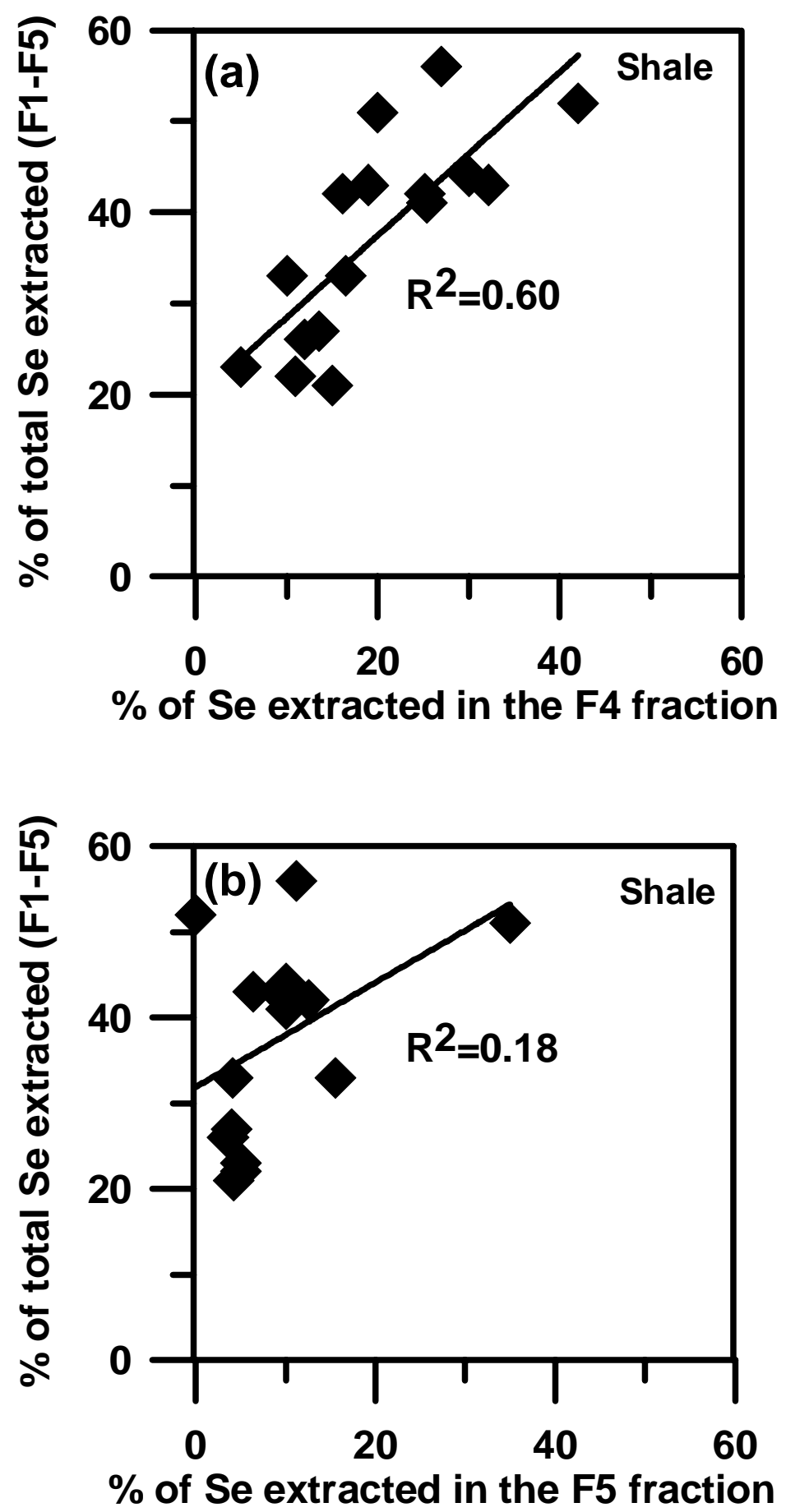

Figure 5-5 Plots of the percentage of selenium extracted from (a) organic (F4) and (b) sulfide (F5) fractions in shale. Samples where extracted selenium is below the detection limit are not included in the graph. 

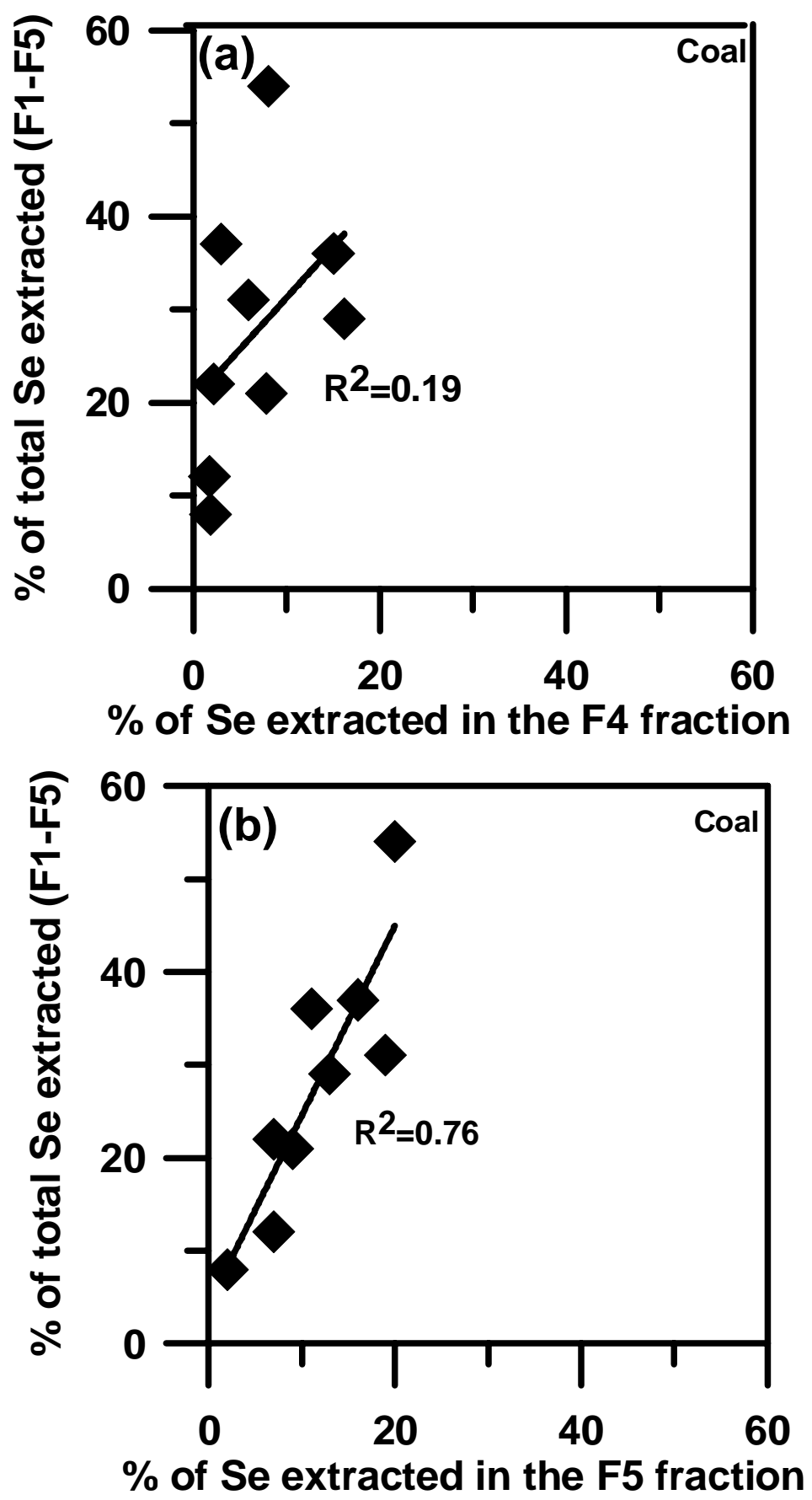

Figure 5-6 Plots of the percentage of selenium extracted from the (a) organic (F4) and (b) sulfide (F5) fraction in coal. Samples where extracted selenium is below the detection limit are not considered in the graph. 
The extraction data were largely an overestimation of the actual field criteria since extracting conditions are rarely encountered in natural geochemical settings. Thus extraction results do not resemble real life situations. Sample alteration after collection might affect the results for extraction to some extent. However, with the exception of two or three lithounits the soluble fraction was not that significant. This implies that sample handling might not be a large problem for these samples. 


\section{Chapter 6 Conclusions}

The present research was an effort to understand the occurrence and distribution of Se from a rock core in south central West Virginia. This was based on analysis of individual strata including coal units and the associated overburden. The rock types included coal, shale, mudstone, sandstone and carbolith. This study also looked at the amount of Se that could be extracted from various fractions of a rock unit by sequential extraction methods.

Several chemical parameters may be useful to predict total Se concentrations. The ABA was one such tool. The paste $\mathrm{pH}$ values also help to form an idea about the nature of distribution of rock types and consequently mobility of several elements. Parameters that suggest neutral $\mathrm{pH}$ conditions and alkaline rock types were paste $\mathrm{pH}$ and NNP.

No statistically significant correlation was found for Se concentration with S concentration or TOC. The high values of TOC for coal as well as high organic S concentration might suggest that organic associations were favorable for the coal units.

The extraction of Se from different fractions varied by rock types. The extracted Se varied from less than $1 \%$ to more than $50 \%$ in the different lithounits of the rock core. In general more than $10 \%$ of the Se was extracted for most rock types except for sandstones.

In coals, approximately $25 \%$ of the total Se was extracted. Se extraction in coal was mostly from the sulfide fractions. Though organic associations were favorable for the coal units, not much of the Se was extracted in the organic fraction. This suggests that in coals the organically associated Se was not present or was not released. Individual coal units of the Winifrede rider coal bed had the highest \% of extracted Se among coals. 
The proximity of non-coal units to coal units is closely linked to Se concentration. Rock units within $2 \mathrm{ft}$ of the coal units had on average about 8 times more Se than rocks situated more than $2 \mathrm{ft}$ away from coal units. Overall, shale had the highest \% extraction of Se. On average about $40 \%$ of Se was extracted from shales. Samples within $2 \mathrm{ft}$ of the coal bed had more than $50 \%$ of Se extracted where the total Se concentration was below $0.6 \mathrm{mg} / \mathrm{kg}$. The coal proximate layers were most probably the most active zone for Se extraction from shale. The proximity of the shale to the coal units was particularly important in the Coalburg coal beds. In shale the organic fraction was the most dominant fraction for Se extraction. The coal proximate mudstone units also approximately had about $40 \%$ Se extracted. The purpose of extraction in this research is to predict the amount of Se extracted from different modes of occurrence, but such conditions are very unlikely to be observed in the geochemical settings of a mine spoil. Thus the results obtained in this research are likely to be an overestimation of what will occur in field conditions.

The conclusions of this study suggest that coal proximate layers have a high total Se concentration. Identification of these zones and appropriate handling techniques can help in reducing Se mobilization from mines to soils and watersheds. 


\section{Chapter 7 Future Work}

Some of the future work suggested are:

- Consider spatially distributed rock cores to see if the relationships developed in this study hold true over wider areas.

- Compare the sequentially extracted data with leaching tests like acid drainage technology initiative (ADTI), humidity cell as well as the extraction columns.

- Consider other factors like ash yield and coal rank for coal samples to look for relationships between Se and these parameters.

- Determine suitable handling techniques of strata that lie in the coal proximate layers.

- Determine the degree of deviation between extraction conditions in the laboratory against field conditions. 


\section{Bibliography}

Butterman, W.C., Brown, R.D. (2004) Mineral commodity profiles-Selenium. United States Geological Survey Open File Report 03-018: 4-20

Bascomb, C.L., Thanigasalam, K. (1978) Comparison of aqueous acetylacetone and potassium pyrophosphate solutions for selective extraction of organic bound $\mathrm{Fe}$ from soils. J. Soil Sci. 29: 382-387

Bernhard, N., Bock, A. (1996) On the mechanism of selenium tolerance in selenium accumulating plants. European Journal of Biochemistry 239 (1): 235-238

Chao, T.T. (1984) Use of partial dissolution techniques in geochemical exploration. J. Geochem. Explor. 20(2): 101-135

Chao, T.T., Sanzolone, R.F. (1989) Fractionation of soil selenium by sequential partial dissolution. J. Soil Sci. Soc. Am. 53: 385-392.

Coleman, R.G., Delevaux, M.H. (1957) Occurrence of selenium in sulfide from some sedimentary rocks of the western United States. Economic Geology 52: 499-527

Coleman, L., Bragg, L.J., Finkelman, R.B. (1993) Distribution and mode of occurrence of selenium in US coals. Environmetal Geochemistry and Health. 15(4):215-227

Davidson, C.M., Ferreira, P.C.S., Ure, A.M. (1999) Some sources of variability in the application of the three stage sequential extraction procedure recommended by BRC to industrially contaminated soil. J. Anal. Chem. 363: 446-451

Dreher, G.B., Finkelman, R.B. (1992) Selenium mobilization in a surface coal mine, Powder River Basin, Wyoming, USA. Environmental Geology Water Sci. 19(3): $155-167$

Drever, J.I. (1998) The geochemistry of natural waters surface: surface and groundwater environments. Prentice Hall: NJ, 2000: 193

Keeney (2005) Personal correspondence by email

Kheboian, C., Bauer, C.F. (1987) Accuracy of selective extraction procedures for metal speciation in model aquatic sediments. Anal. Chem. 59: 1417-1423 
Kunli, L., Lirong, X., Jianan, T., Douhu, W., Lianhua, X. (2004) Slenium source in the selenosis area of the Daba region, South Qinling Mountain, China. Environmental Geology 45: 426-432

La Force, M.J., Fendorf, S. (2000) Solid phase iron characterization during common selective sequential extractions. Soil Sci. Soc. Am. J 64: 1608-1615

Lakin, H.W., Davidson, D.F. (1973) Selenium. United States Mineral Resources. U.S. geological Survey professional paper 820: 573-576

Lussier, C., Veiga, V., Baldwin, S. (2003) The geochemistry of selenium associated with coal waste in the Elk River valley, Canada. Environmental Geology 44: 905-913

Lynch, J.J. (1970) The determination of copper, nickel and cobalt in rocks by Atomic Absorption Spectrometry using a cold leach. Geochemical Exploration proceedings. 11: $313-314$

Martens, D.A., Suarez, D.L. (1997) Selenium speciation of soil/sediment determined with sequential extractions and HGAAS. Environ. Sci. Technol. 31: 133-139

McNeal, J.M., Balistrieri, L.S. (1989) Geochemistry and occurrence of selenium: an overview. In Jacobs L.W. eds. Selenium in agriculture and the environment. Soil Sciences Society of America Inc. Madison, Wisconsin: 1-13

Mullennex, R. (2005) Stratigraphic distribution of selenium in Upper Kanawha-Lower Allegheny Foramtion strata at a location in southwestern West Virginia. Presented at the Pittsburgh Coal Conference, Pittsburgh, PA 2005 (Poster)

Naftz, D.L., Rice, J. (1989) Geochemical processes controlling selenium in groundwater after mining Powder River basin, Wyoming, U.S.A Appl. Geochem. 4: 565-576

Nelson, K.W., Bundy, S.D. (1980) Environmental aspects of selenium and tellurium. Proceedings of the International Symposium of industrial uses of selenium and tellurium, Toronto, Canada: 18-24

Neuzil, S.G., Dulong, F.T., Cecil C.B. (2005) Spatial trends in ash yield, sulfur and selenium and other selected trace element concentrations in coal beds of the Appalachian Plateau region. USGS Open File Report 2005-1330 
Opresko, D.M. (1993) Toxicity summary for selenium. In The risk assessment information system - selenium. 7782:49-52

Presser, T.S. (1994) Geologic origin and pathways of selenium from California Coast Range to the west-central San Joaquin Valley, In Frankenberger, W.T. Jr., and Benson Sally eds. Selenium in the environment, New York, Marcel Dekker, Inc: 139-155

Rait N., Aruscavage, P.,J. (2005) The determination of forms of sulfur in coal. In The methods for sampling and inorganic analysis of coal U.S. Geological Survey Bulletin 1823

Renton, J.J., Stiller, A.H., Rymer, T.E. (1989) The acid producing potential of the various rock units associated with the mining of coal. Mining Science and Technology 9: $137-147$

Rose, A.W., Cravotta, C.A. (1998) Geochemistry of coal mine drainage. Coal mine drainage prediction and pollution prevention in Pennsylvania, Harrrisburg, PA. Pennsylvania Department of Environmental Protection, 5600-BK-DEP-2256: 1.11.22

Sharmasarkar, S., Vance, G.F. (1997) Extraction and distribution of soil organic and inorganic selenium in coal mine environment of Wyoming, U.S.A Environ. Geol. 29:17-22

Sharmasarkar S., Vance, G.F. (2002) Ecological risk assessment - soil and plant selenium at a reclaimed uranium mine. J. Environ. Quality 31: 1516-1521

Shiowatana, J., McLaren, R.G., Chanmekha, N., Samphao, A. (2001a) Fractionation of As in soil by a continuous flow sequential extraction method. J. Environ. Qual. 30: 1940-1949

Shiowatana, J., Tantidanai, N., Nookabkaew, S., Nacopricha, D. (2001b) A novel continuous flow sequential extraction procedure for metal speciation in solids. J. Environ. Qual. 30:1195-1205 
Skousen, J., Simmons, J., McDonald, L.M., Ziemkiewicz, P. (2002) Acid-base accounting to predict post mining drainage quality on surface mines. Journal of Environmental Quality 31: 2033-2044

Tessier, A. Campbell, P.G.C., Bisson, M. (1979) Sequential extraction procedure for the speciation of particulate trace metals. Anal. Chem. 51:844-851

U.S. Environmental Protection Agency (2002) http://www.epa.gov (accessed September, 2004)

U.S. National Committee for Geochemistry (1980) Trace element geochemistry of coal resource development related to environmental quality and health. National Academy Press, Washington D.C.: 132

Vance, G.F., Fadlelmawla, A.A., See, R.B., Reddy, K.J. (1995) Role of natural organic solutes on the sorption of selenium by coal mine backfill core samples from the Powder River Basin, Wyoming. National meeting of the American Society for Surface Mining and Reclamation, Wyoming: 246-256

Weres, O., Jaouni, A.R., Tsao, L. (1989) The distribution, speciation and cycling of selenium in a sedimentary environment, Kesterson Reservoir, California, U.S.A. Appl. Geochem. 4:543-563

Wright, M.T., Parker, D.R., Amrhein, C. (2003) Critical evaluation of the ability of sequential extraction procedures to quantify discrete forms of selenium in sediments and soils. Environ. Sci. Technol. 37:20 -25

West Virginia Geological and Economic Survey, WVGES (2002a) www.wvgs.wvnet.edu/www.datastat/te (Accessed September, 2004)

West Virginia Geological and Economic Survey, WVGES (2002b) Coal Quality Database. Requests for data may be directed through the website www.wvgswvnet.edu or by mail at 1 Mont Chateau Road, Morgantown, WV 26508 
Appendix 1 Table A-1: Site and bulk analytical data for the rock core

(Page 1 of 3)

\begin{tabular}{|c|c|c|c|c|c|c|c|c|c|c|}
\hline $\begin{array}{c}\text { Sample } \\
\text { No. }\end{array}$ & $\begin{array}{c}\text { Depth } \\
\text { (Bottom) } \\
(\mathrm{ft})\end{array}$ & $\begin{array}{c}\text { Thickness } \\
(\mathrm{ft})\end{array}$ & Rock Type & $\begin{array}{l}\text { Coal } \\
\text { Bed }\end{array}$ & $\begin{array}{c}\text { Sulfur } \\
(\%)\end{array}$ & MPA** & $N P * *$ & NNP** & $\begin{array}{c}\text { TOC } \\
\text { (mg/kg) }\end{array}$ & Paste pH \\
\hline *1 & 28 & 5 & Sandstone & Coalburg & $<0.01$ & 0.31 & 0.3 & 0.02 & 1000 & 5.8 \\
\hline *2 & 33 & 5 & Sandstone & Coalburg & $<0.01$ & 0.31 & 1.7 & 1.38 & 100 & 6.3 \\
\hline *3 & 38 & 5 & Sandstone & Coalburg & $<0.01$ & 0.31 & 0.1 & -0.3 & 200 & 6.3 \\
\hline 4 & 43 & 5 & Sandstone & Coalburg & $<0.01$ & 0.31 & 1 & 0.71 & 100 & 6.4 \\
\hline 5 & 48 & 5 & Sandstone & Coalburg & $<0.01$ & 0.31 & 0 & -0.3 & 200 & 6.4 \\
\hline 6 & 53 & 5 & Sandstone & Coalburg & $<0.01$ & 0.31 & 0.9 & 0.59 & 20 & 6.5 \\
\hline 7 & 58 & 5 & Sandstone & Coalburg & $<0.01$ & 0.31 & 1.2 & 0.86 & 300 & 7 \\
\hline *8 & 63.3 & 5.35 & Sandstone & Coalburg & $<0.01$ & 0.31 & 1.4 & 1.11 & 300 & 6.5 \\
\hline *9 & 64.7 & 1.4 & Sandstone/Coal & Coalburg & 0.2 & 2.5 & 0.3 & -2.2 & 138000 & 5.8 \\
\hline *10 & 70 & 5.2 & Sandstone & Coalburg & $<0.01$ & 0.31 & 6.1 & 5.81 & 2200 & 6.6 \\
\hline 11 & 74.9 & 5 & Sandstone & Coalburg & $<0.01$ & 0.31 & 8.2 & 7.91 & 3800 & 6.3 \\
\hline *12 & 80.1 & 5.15 & Sandstone & Coalburg & $<0.01$ & 0.31 & 10 & 9.67 & 4700 & 7 \\
\hline *13 & 80.5 & 0.4 & Sandstone/Coal & Coalburg & 0.08 & 2.5 & 13 & 10.3 & 57200 & 7.4 \\
\hline *14 & 83.5 & 3 & Shale & Coalburg & 0.04 & 1.25 & 6.7 & 5.49 & 10800 & 5.4 \\
\hline *15 & 86.5 & 3 & Shale & Coalburg & 0.04 & 1.25 & 8.2 & 6.95 & 16600 & 5.8 \\
\hline *16 & 88.5 & 2.05 & Shale & Coalburg & 0.85 & 16.25 & -702 & -718 & 4500 & 4.5 \\
\hline *16A & 89.2 & 0.65 & Coal & Coalburg & 6.22 & 84.38 & -12 & -96 & 537000 & 4.5 \\
\hline *17 & 91.7 & 2.5 & Mudstone & Coalburg & 1.22 & 21.88 & 2.4 & -20 & 1600 & 4.1 \\
\hline 18 & 96.1 & 4.45 & Sandstone & Coalburg & 0.88 & 16.56 & -8.8 & -25 & 1000 & 4.1 \\
\hline 19 & 101 & 4.85 & Sandstone & Coalburg & 0.17 & 5.31 & 88 & 82.4 & 3100 & 8.4 \\
\hline 20 & 105.9 & 4.95 & Sandstone & Coalburg & $<0.01$ & 0.31 & 9.4 & 9.08 & 2500 & 8.2 \\
\hline 21 & 110.2 & 4.25 & Sandstone & Coalburg & $<0.01$ & 0.31 & 12 & 11.9 & 500 & 8.3 \\
\hline 22 & 115 & 4.8 & Sandstone & Coalburg & 0.01 & 0.31 & 15 & 14.3 & 2800 & 8.3 \\
\hline 23 & 118.9 & 3.9 & Sandstone & Coalburg & 0.15 & 4.69 & 12 & 7.2 & 1900 & 7.7 \\
\hline 24 & 119.7 & 0.8 & Sandstone & Coalburg & $<0.01$ & 0.31 & 4.3 & 4 & 500 & 7.8 \\
\hline 25 & 123.8 & 4.15 & Sandstone & Coalburg & 0.19 & 5.94 & 29 & 23.5 & 5000 & 7.9 \\
\hline 26 & 127 & 3.15 & Mudstone/Sandstone & Coalburg & 0.13 & 4.06 & 9.7 & 5.6 & 11400 & 7.9 \\
\hline *27 & 130 & 3 & Mudstone/Sandstone & Coalburg & 0.09 & 2.81 & 11 & 8.18 & 11600 & 8 \\
\hline *28 & 133 & 3 & Mudstone & Coalburg & 0.14 & 4.38 & 11 & 6.89 & 17500 & 8.1 \\
\hline
\end{tabular}


Appendix 1 Table A-1: Site and bulk analytical data for the rock core

(Page 2 of 3)

\begin{tabular}{|c|c|c|c|c|c|c|c|c|c|c|}
\hline $\begin{array}{c}\text { Sample } \\
\text { No. }\end{array}$ & $\begin{array}{c}\text { Depth } \\
\text { (Bottom) } \\
(\mathrm{ft})\end{array}$ & $\begin{array}{c}\text { Thickness } \\
(\mathrm{ft})\end{array}$ & Rock Type & Coal Bed & $\begin{array}{c}\text { Sulfur } \\
(\%)\end{array}$ & MPA** $^{*}$ & $\mathbf{N P * *}$ & NNP** & $\begin{array}{c}\text { TOC } \\
\text { (mg/kg) }\end{array}$ & Paste pH \\
\hline 29 & 135.5 & 2.55 & Mudstone & Coalburg & 0.15 & 4.69 & 11 & 6.53 & 13100 & 8 \\
\hline 30 & 140 & 4.35 & Sandstone & Coalburg & 0.02 & 0.63 & 23 & 22.2 & 5100 & 8.5 \\
\hline 31 & 145 & 5.1 & Sandstone & Coalburg & 0.06 & 1.88 & 8.7 & 6.84 & 6300 & 7.6 \\
\hline 32 & 149 & 4 & Sandstone & Coalburg & 0.33 & 10.31 & 9.9 & -0.4 & 11000 & 7.2 \\
\hline *33 & 1505 & 1.55 & Sandstone & Coalburg & 0.54 & 7.19 & 9.7 & 2.54 & 40000 & 6.4 \\
\hline *34 & 153.5 & 3 & Shale & Coalburg & 0.19 & 5.94 & 8.1 & 2.18 & 17800 & 7.8 \\
\hline *35 & 157 & 3.45 & Shale & Coalburg & 0.01 & 0.31 & 5.2 & 4.87 & 5200 & 8.1 \\
\hline *36 & 157.3 & 0.35 & Sandstone & Coalburg & $<0.01$ & 0.31 & 1.8 & 1.48 & 3100 & 7.8 \\
\hline *37 & 157.8 & 0.5 & Sandstone/Carbolith & Coalburg & 0.11 & 3.44 & 1.6 & -1.9 & 115000 & 7.4 \\
\hline *37A & 158.8 & 1 & Coal & Coalburg & 0.44 & 1.88 & 3.6 & 1.67 & 406000 & 7.8 \\
\hline *37B & 161 & 2.05 & Coal & Coalburg & 0.76 & 0.63 & 1.5 & 0.82 & 619000 & 7.7 \\
\hline *38 & 163 & 2.1 & Mudstone & Winifrede Riders & 0.03 & 0.94 & 3.5 & 2.58 & 5000 & 8.2 \\
\hline *39 & 164.6 & 1.6 & Sandstone/Carbolith & Winifrede Riders & $<0.01$ & 0.31 & 3.8 & 3.53 & 14900 & 6.2 \\
\hline *40 & 16 & 4.4 & Sandstone & Winifrede Riders & $<0.01$ & 0.31 & 3.1 & 2.76 & 800 & 7.4 \\
\hline 41 & 174 & 5 & Sandstone & Winifrede Riders & $<0.01$ & 0.31 & 2.2 & 1.92 & 300 & 7.5 \\
\hline 42 & 179 & 5 & Sandstone & Winifrede Riders & $<0.01$ & 0.31 & 1.8 & 1.53 & 500 & 7.5 \\
\hline 43 & 184 & 5 & Sandstone & Winifrede Riders & $<0.01$ & 0.31 & 2.7 & 2.34 & 500 & 7.6 \\
\hline *44 & 189 & 5 & Sandstone & Winifrede Riders & $<0.01$ & 0.31 & 3.3 & 3.01 & 300 & 8 \\
\hline 45 & 191 & 2 & Sandstone & Winifrede Riders & $<0.01$ & 0.31 & 31 & 30.4 & 600 & 8.2 \\
\hline 46 & 195 & 4 & Sandstone & Winifrede Riders & 0.02 & 0.63 & 8.5 & 7.86 & 5100 & 8.2 \\
\hline 47 & 198.5 & 3.5 & Sandstone & Winifrede Riders & $<0.01$ & 0.31 & 5.8 & 5.49 & 2900 & 8.1 \\
\hline *48 & 200.6 & 2.1 & Shale & Winifrede Riders & 0.3 & 9.38 & 8.4 & -0.9 & 15200 & 8.1 \\
\hline *49 & 201.8 & 1.2 & Carbolith & Winifrede Riders & 0.37 & 11.56 & 7.6 & -4 & 138000 & 8.1 \\
\hline$\star 50$ & 202.2 & 0.45 & Shale & Winifrede Riders & 0.15 & 4.69 & 3.1 & -1.6 & 368000 & 8 \\
\hline$\star 50 A$ & 203.2 & 1 & Coal & Winifrede Riders & 1.8 & 15.63 & -5.1 & -21 & 597000 & 7.2 \\
\hline *51 & 203.3 & 0.1 & Shale & Winifrede Riders & 1.34 & 17.81 & -4.4 & -22 & 193000 & 6.3 \\
\hline *52 & 206.3 & 3 & Sandstone/Mudstone & Winifrede Riders & 0.04 & 1.25 & 8.8 & 7.59 & 16700 & 8.1 \\
\hline *53 & 27.8 & 1.45 & Sandstone & Winifrede Riders & 0.06 & 1.88 & 9.2 & 7.33 & 372000 & 7.9 \\
\hline *54 & 208 & 0.2 & Coal & Winifrede Riders & 0.69 & 3.13 & 5.5 & 2.39 & 500000 & 6.7 \\
\hline *55 & 211 & 3 & Shale & Winifrede Riders & 0.05 & 1.56 & 16 & 14.9 & 21700 & 8.2 \\
\hline$\star 56$ & 213.2 & 2.25 & Shale & Winifrede Riders & 0.01 & 0.31 & 4.6 & 4.25 & 7400 & 8.2 \\
\hline
\end{tabular}


Appendix 1 Table A-1: Site and bulk analytical data for the rock core

(Page 3 of 3)

\begin{tabular}{|c|c|c|c|c|c|c|c|c|c|c|}
\hline $\begin{array}{c}\text { Sample } \\
\text { No. }\end{array}$ & $\begin{array}{c}\text { Depth } \\
(\mathrm{ft})\end{array}$ & $\begin{array}{c}\text { Thickness } \\
(\mathrm{ft})\end{array}$ & Rock Type & Coal Bed & $\begin{array}{c}\text { Sulfur } \\
(\%)\end{array}$ & MPA** & $N P * *$ & NNP** & $\begin{array}{c}\text { TOC } \\
(\mathrm{mg} / \mathrm{kg})\end{array}$ & Paste pH \\
\hline *60 & 223.4 & 3 & Shale & Upper Winifrede & 0.04 & 1.25 & 13 & 11.4 & 18500 & 8.3 \\
\hline *57 & 213.6 & 0.31 & Carbolith & Winifrede Riders & 0.37 & 1.56 & 0.13 & -1.43 & 346000 & 8.2 \\
\hline *57A & 214.4 & 0.89 & Coal & Winifrede Riders & 0.88 & 1.88 & 0.13 & -1.75 & 661000 & 7.6 \\
\hline *61 & 225.8 & 2.4 & Sandstone/Shale & Upper Winifrede & 0.03 & 0.94 & 13 & 12.4 & 14900 & 8 \\
\hline *62 & 226 & 0.15 & Carbolith/Mudstone & Upper Winifrede & 0.09 & 2.81 & 4 & 1.2 & 109000 & 7.1 \\
\hline *62A & 227.1 & 1.1 & Coal & Upper Winifrede & 0.6 & 1.88 & 2 & 0.1 & 422000 & 7.9 \\
\hline *63 & 227.7 & 0.63 & Shale & Upper Winifrede & 0.06 & 1.88 & 5.8 & 3.92 & 98900 & 7.7 \\
\hline *63A & 229.5 & 1.77 & Coal & Upper Winifrede & 0.95 & 2.19 & -0.9 & -3.1 & 692000 & 7.8 \\
\hline 64 & 231.6 & 2.1 & Mudstone & Upper Winifrede & 0.01 & 0.31 & 9.6 & 9.3 & 6100 & 7.6 \\
\hline *65 & 234.6 & 3 & Shale & Upper Winifrede & 0.16 & 5 & 11 & 5.99 & 8300 & 7.6 \\
\hline 66 & 237.6 & 3 & Shale & Upper Winifrede & 0.03 & 0.94 & 11 & 10.2 & 9400 & 8 \\
\hline 67 & 240.6 & 3 & Shale & Upper Winifrede & 0.04 & 0.94 & 13 & 11.8 & 9800 & 8.1 \\
\hline 68 & 243.6 & 3 & Shale & Upper Winifrede & 0.04 & 1.25 & 14 & 12.9 & 10700 & 8.2 \\
\hline *69 & 246.6 & 3 & Shale & Upper Winifrede & 0.03 & 0.94 & 21 & 20.1 & 9700 & 8.3 \\
\hline *70 & 249.6 & 3 & Shale & Upper Winifrede & 0.03 & 0.94 & 19 & 18.2 & 10400 & 8.2 \\
\hline *71 & 252.4 & 2.85 & Shale & Upper Winifrede & 0.04 & 1.25 & 17 & 16 & 13000 & 8.1 \\
\hline *72 & 253.4 & 1 & Shale & Upper Winifrede & 0.04 & 1.25 & 9.4 & 8.18 & 10700 & 7.9 \\
\hline *73 & 253.7 & 0.3 & Sandstone/Coal & Upper Winifrede & 0.05 & 1.56 & 7.4 & 5.87 & 34100 & 7.9 \\
\hline *73A & 256.3 & 2.53 & Coal & Upper Winifrede & 0.68 & 1.56 & 0.9 & -0.7 & 643000 & 7.9 \\
\hline *73B & 257.2 & 0.92 & Coal & Upper Winifrede & 1.75 & 17.19 & -4.1 & -21 & 247000 & 7.5 \\
\hline$\star 74$ & 257.3 & 0.1 & Shale & Winifrede & 0.37 & 1.88 & 4.8 & 2.95 & 132000 & 6.7 \\
\hline *75 & 20.7 & 3.4 & Shale & Winifrede & 0.02 & 0.63 & 6.5 & 5.88 & 12000 & 7.6 \\
\hline *76 & 262.9 & 2.2 & Sandstone/Shale & Winifrede & 0.03 & 0.94 & 6.5 & 5.52 & 9700 & 7.6 \\
\hline *76A & 264.8 & 1.95 & Coal & Winifrede & 0.68 & 1.25 & 1 & -0.3 & 547000 & 8.1 \\
\hline$\star 77$ & 265.4 & 0.55 & Mudstone & Winifrede & 0.06 & 1.88 & 3.6 & 1.74 & 67200 & 7.8 \\
\hline *78 & 266.7 & 1.35 & Mudstone & Winifrede & 0.03 & 0.94 & 5.8 & 4.86 & 9800 & 7.9 \\
\hline
\end{tabular}

* Indicate samples subjected to sequential extraction tests

** Concentrations for MPA, NP and NNP are in tons/1000 tons of material 


\begin{tabular}{|c|c|c|c|c|c|c|}
\hline $\begin{array}{c}\text { Sample } \\
\text { ID }\end{array}$ & $\begin{array}{c}\text { Depth } \\
\text { (ft) }\end{array}$ & Lithology & $\begin{array}{l}\text { Total Se } \\
(\mathrm{mg} / \mathrm{kg}) \\
\end{array}$ & $\begin{array}{c}\text { Se extracted + residue } \\
(\mathrm{mg} / \mathrm{kg})\end{array}$ & $\begin{array}{c}\text { Sum of extracted Se } \\
(\mathrm{mg} / \mathrm{kg})\end{array}$ & $\begin{array}{c}\text { Se extracted } \\
(\%) \\
\end{array}$ \\
\hline 34 & 153.55 & Shale & 0.40 & 0.39 & 0.23 & 56 \\
\hline 36 & 157.35 & Sandstone & 0.96 & 0.90 & 0.05 & 5 \\
\hline 35 & 157.00 & Shale & 0.52 & 0.65 & 0.27 & 52 \\
\hline 33 & 150.55 & Sandstone & 0.28 & 0.20 & 0.00 & 0 \\
\hline 37 & 158.85 & Carbolith & 1.26 & 1.01 & 0.01 & 1 \\
\hline $38 \mathrm{~A}$ & 163.00 & Mudstone & 0.32 & 0.31 & 0.10 & 32 \\
\hline $39 A$ & 164.60 & Carbolith & 0.54 & 0.53 & 0.04 & 8 \\
\hline $40 \mathrm{~A}$ & 169.00 & Sandstone & $<0.20$ & $<0.20$ & 0.00 & 0 \\
\hline 48 & 200.60 & Shale & 0.30 & 0.30 & 0.15 & 51 \\
\hline 49 & 201.80 & Carbolith & 3.38 & 3.35 & 1.08 & 32 \\
\hline $37 \mathrm{~A}$ & 157.85 & Sandstone/Carbolith & 3.72 & 3.23 & 0.80 & 22 \\
\hline $37 B$ & 160.90 & Coal & 0.42 & 0.43 & 0.15 & 36 \\
\hline 28 & 133.00 & Mudstone & 0.28 & 0.24 & 0.03 & 11 \\
\hline 27 & 130.00 & Mudstone/Sandstone & 0.24 & 0.21 & 0.01 & 3 \\
\hline 15 & 86.50 & Shale & 0.30 & 0.30 & 0.13 & 43 \\
\hline 16 & 88.55 & Shale & 0.42 & 0.37 & 0.17 & 41 \\
\hline $50 A$ & 203.25 & Coal & 1.16 & 1.35 & 0.43 & 37 \\
\hline 50 & 202.25 & Shale & 2.58 & 2.56 & 1.08 & 42 \\
\hline $57 \mathrm{~A}$ & 214.45 & Coal & 0.50 & 0.48 & 0.27 & 54 \\
\hline 57 & 213.56 & Carbolith & 7.12 & 7.07 & 0.70 & 10 \\
\hline 52 & 206.35 & Mudstone & 0.36 & 0.36 & 0.05 & 14 \\
\hline 54 & 208.00 & Coal & 1.00 & 0.85 & 0.29 & 29 \\
\hline 53 & 207.80 & Sandstone & 0.28 & 0.27 & 0.02 & 7 \\
\hline 55 & 211.00 & Shale & 0.26 & 0.26 & 0.05 & 21 \\
\hline 62 & 226.00 & Carbolith & 9.44 & 8.52 & 1.35 & 16 \\
\hline $62 A$ & 227.10 & Coal & 5.96 & 4.70 & 0.71 & 12 \\
\hline 61 & 225.85 & Shale & 1.06 & 0.95 & 0.35 & 33 \\
\hline 63 & 227.73 & Shale & 5.36 & 4.25 & 2.36 & 44 \\
\hline 73 & 253.75 & Coal & 1.18 & 1.11 & 0.10 & 8 \\
\hline $73 A$ & 256.28 & Coal & $<0.20$ & $<0.20$ & $<0.20$ & $<0.20$ \\
\hline 72 & 253.45 & Shale & 0.64 & 0.62 & 0.28 & 43 \\
\hline
\end{tabular}




\begin{tabular}{|c|c|c|c|c|c|c|}
\hline $\begin{array}{l}\text { Sample } \\
\text { ID }\end{array}$ & $\begin{array}{l}\text { Depth } \\
\text { (ft) }\end{array}$ & Lithology & $\begin{array}{l}\text { Total } \\
\text { Se } \\
\text { (mg/kg) }\end{array}$ & $\begin{array}{c}\text { Se extracted +residue } \\
(\mathrm{mg} / \mathrm{kg})\end{array}$ & $\begin{array}{c}\text { Sum of } \\
\text { extracted } \\
\text { Se } \\
\text { (mg/kg) }\end{array}$ & $\begin{array}{c}\text { Se extracted } \\
(\%) \\
\end{array}$ \\
\hline $73 B$ & 257.20 & Coal & 2.02 & 2.20 & 0.21 & 10 \\
\hline 77 & 265.40 & Mudstone & 2.08 & 0.50 & 0.40 & 19 \\
\hline $76 \mathrm{~A}$ & 264.85 & Coal & 2.06 & 2.04 & 0.44 & 21 \\
\hline 76 & 262.90 & Shale & 0.76 & 0.69 & 0.20 & 26 \\
\hline 74 & 257.30 & Shale & 1.00 & 0.94 & 0.21 & 22 \\
\hline 75 & 260.70 & Shale & 0.34 & 0.34 & 0.03 & 33 \\
\hline 51 & 203.35 & Shale & 1.16 & 0.96 & 0.31 & 27 \\
\hline 17 & 91.70 & Mudstone & 0.20 & 0.19 & 0.07 & 35 \\
\hline $16 \mathrm{~A}$ & 89.20 & Coal & $<0.20$ & $<0.20$ & $<0.20$ & $<0.20$ \\
\hline 78 & 266.75 & Mudstone & 0.30 & 0.42 & 0.17 & 56 \\
\hline 56 & 213.25 & Shale & 0.78 & 0.76 & 42 & 42 \\
\hline 2 & 33.00 & Sandstone & $<0.20$ & $<0.20$ & $<0.20$ & $<0.20$ \\
\hline 8 & 63.35 & Sandstone & $<0.20$ & $<0.20$ & $<0.20$ & $<0.20$ \\
\hline 3 & 38.00 & Sandstone & $<0.20$ & $<0.20$ & $<0.20$ & $<0.20$ \\
\hline 1 & 28.00 & Sandstone & $<0.20$ & $<0.20$ & $<0.20$ & $<0.20$ \\
\hline 9 & 64.75 & Sandstone & $<0.20$ & $<0.20$ & $<0.20$ & $<0.20$ \\
\hline 14 & 83.50 & Shale & $<0.20$ & $<0.20$ & $<0.20$ & $<0.20$ \\
\hline 12 & 80.10 & Sandstone & $<0.20$ & $<0.20$ & $<0.20$ & $<0.20$ \\
\hline 13 & 80.50 & Sandstone & $<0.20$ & $<0.20$ & $<0.20$ & $<0.20$ \\
\hline 10 & 69.95 & Sandstone & $<0.20$ & $<0.20$ & $<0.20$ & $<0.20$ \\
\hline $63 \mathrm{~A}$ & 229.50 & Coal & 1.98 & 1.67 & 31 & 31 \\
\hline 60 & 223.45 & Shale & $<0.20$ & $<0.20$ & $<0.20$ & $<0.20$ \\
\hline 71 & 252.45 & Shale & $<0.20$ & $<0.20$ & $<0.20$ & $<0.20$ \\
\hline 70 & 249.60 & Shale & 0.24 & 0.17 & 23 & 23 \\
\hline 69 & 246.60 & Shale & $<0.20$ & $<0.20$ & $<0.20$ & $<0.20$ \\
\hline 59 & 220.45 & Shale & $<0.20$ & $<0.20$ & $<0.20$ & $<0.20$ \\
\hline
\end{tabular}

Notes: Total Se based on bulk chemical analysis; Sum of extracted Se + residue includes solution-extracted Se plus analysis of residue solids; Sum of extracted Se includes only the solution-extracted mass; Se extracted (\%) is calculated using the total Se concentration. 
Appendix 1 Table A-3: Mean values and relative standard deviation of replicate samples in sequential extraction

(Page 1 of 4)

\begin{tabular}{|c|c|c|c|c|}
\hline Sample ID & Fraction & $\begin{array}{c}\text { Mean } \\
\text { (ug/kg) }\end{array}$ & $\begin{array}{l}\text { RSD } \\
(\%)\end{array}$ & $\begin{array}{c}\text { No. of replicates } \\
\text { for extraction }\end{array}$ \\
\hline \multirow[t]{5}{*}{37} & $\mathrm{~F} 1$ & 450 & 6 & 3 \\
\hline & F2 & 42 & 0 & 3 \\
\hline & F3 & $<2$ & 0 & 2 \\
\hline & $\mathrm{F} 4$ & 72 & 12 & 3 \\
\hline & $\mathrm{F} 5$ & 219 & 14 & 3 \\
\hline \multirow[t]{5}{*}{$50 \mathrm{~A}$} & F1 & 144 & 18 & 2 \\
\hline & $\mathrm{F} 2$ & 81 & 16 & 2 \\
\hline & F3 & $<2$ & 0 & 2 \\
\hline & $\mathrm{F} 4$ & $<2$ & 0 & 2 \\
\hline & $\mathrm{F} 5$ & 201 & 15 & 2 \\
\hline \multirow[t]{5}{*}{$57 \mathrm{~A}$} & F1 & 236 & 2 & 2 \\
\hline & $\mathrm{F} 2$ & 15 & 14 & 2 \\
\hline & F3 & $<2$ & 0 & 2 \\
\hline & $\mathrm{F} 4$ & $<2$ & 0 & 2 \\
\hline & F5 & 17 & 41 & 2 \\
\hline \multirow[t]{5}{*}{54} & F1 & $<2$ & 0 & 2 \\
\hline & $\mathrm{F} 2$ & $<2$ & 0 & 2 \\
\hline & F3 & $<2$ & 0 & 2 \\
\hline & $\mathrm{F} 4$ & 144 & 24 & 2 \\
\hline & $\mathrm{F} 5$ & 144 & 12 & 2 \\
\hline \multirow[t]{5}{*}{$62 \mathrm{~A}$} & F1 & 93 & 23 & 2 \\
\hline & $\mathrm{F} 2$ & 30 & 28 & 2 \\
\hline & F3 & 123 & 10 & 0 \\
\hline & F4 & 105 & 4 & 2 \\
\hline & F5 & 359 & 7 & 2 \\
\hline \multirow[t]{5}{*}{$73 \mathrm{~A}$} & F1 & 108 & 0 & 2 \\
\hline & F2 & 18 & 47 & 2 \\
\hline & F3 & $<2$ & 0 & 2 \\
\hline & $\mathrm{F} 4$ & 12 & 0 & 2 \\
\hline & F5 & 24 & 0 & 2 \\
\hline \multirow[t]{5}{*}{$73 B$} & F1 & 51 & 8 & 2 \\
\hline & $\mathrm{F} 2$ & $<2$ & 0 & 2 \\
\hline & F3 & $<2$ & 0 & 2 \\
\hline & F4 & 78 & 0 & 2 \\
\hline & F5 & 78 & 11 & 2 \\
\hline \multirow[t]{5}{*}{$76 \mathrm{~A}$} & F1 & 24 & 0 & 2 \\
\hline & $\mathrm{F} 2$ & 69 & 18 & 2 \\
\hline & F3 & $<2$ & 0 & 1 \\
\hline & F4 & 168 & 5 & 2 \\
\hline & F5 & 174 & 0 & 2 \\
\hline
\end{tabular}


Appendix 1 Table A-3: Mean values and relative standard deviation of replicate samples in sequential extraction

(Page 2 of 4)

\begin{tabular}{|c|c|c|c|c|}
\hline Sample ID & Fraction & $\begin{array}{c}\text { Mean } \\
\text { (ug/kg) }\end{array}$ & $\begin{array}{l}\text { RSD } \\
(\%)\end{array}$ & $\begin{array}{c}\text { No. of replicates } \\
\text { for extraction }\end{array}$ \\
\hline \multirow[t]{5}{*}{$63 A$} & $\mathrm{~F} 1$ & 72 & 12 & 3 \\
\hline & $\mathrm{F} 2$ & 60 & 0 & 3 \\
\hline & F3 & $<2$ & 0 & 2 \\
\hline & $\mathrm{F} 4$ & 135 & 16 & 3 \\
\hline & $\mathrm{F} 5$ & 344 & 6 & 3 \\
\hline \multirow[t]{5}{*}{$38 \mathrm{~A}$} & $\mathrm{~F} 1$ & $<2$ & 0 & 2 \\
\hline & $\mathrm{F} 2$ & 48 & 18 & 2 \\
\hline & F3 & $<2$ & 0 & 0 \\
\hline & $\mathrm{F} 4$ & 54 & 0 & 2 \\
\hline & F5 & $<2$ & 0 & 2 \\
\hline \multirow[t]{5}{*}{28} & F1 & $<2$ & 0 & 3 \\
\hline & $\mathrm{F} 2$ & 12 & 50 & 3 \\
\hline & F3 & $<2$ & 0 & 2 \\
\hline & $\mathrm{F} 4$ & 20 & 17 & 3 \\
\hline & F5 & $<2$ & 0 & 3 \\
\hline \multirow[t]{5}{*}{77} & F1 & 32 & 11 & 3 \\
\hline & $\mathrm{F} 2$ & 40 & 9 & 3 \\
\hline & F3 & $<2$ & 0 & 1 \\
\hline & $\mathrm{F} 4$ & 202 & 7 & 3 \\
\hline & F5 & 122 & 3 & 3 \\
\hline \multirow[t]{5}{*}{17} & $\mathrm{~F} 1$ & $<2$ & 0 & 3 \\
\hline & $\mathrm{F} 2$ & $<2$ & 0 & 3 \\
\hline & F3 & $<2$ & 0 & 0 \\
\hline & $\mathrm{F} 4$ & 44 & 8 & 3 \\
\hline & $\mathrm{F} 5$ & 26 & 13 & 3 \\
\hline \multirow[t]{5}{*}{78} & F1 & 18 & 33 & 3 \\
\hline & $\mathrm{F} 2$ & 66 & 24 & 3 \\
\hline & F3 & $<2$ & 0 & 0 \\
\hline & $\mathrm{F} 4$ & 36 & 33 & 3 \\
\hline & F5 & 46 & 15 & 3 \\
\hline \multirow[t]{5}{*}{34} & F1 & 36 & 17 & 3 \\
\hline & $\mathrm{F} 2$ & 38 & 24 & 3 \\
\hline & F3 & $<2$ & 0 & 2 \\
\hline & $\mathrm{F} 4$ & 106 & 9 & 3 \\
\hline & F5 & 44 & 8 & 3 \\
\hline \multirow[t]{5}{*}{35} & F1 & 21 & 20 & 2 \\
\hline & $\mathrm{F} 2$ & 30 & 50 & 2 \\
\hline & F3 & $<2$ & 0 & 1 \\
\hline & $\mathrm{F} 4$ & 219 & 10 & 2 \\
\hline & F5 & $<2$ & 0 & 2 \\
\hline
\end{tabular}


Appendix 1 Table A-3: Mean values and relative standard deviation of replicate samples in sequential extraction

\begin{tabular}{|c|c|c|c|c|}
\hline Sample ID & Fraction & $\begin{array}{l}\text { Mean } \\
\text { (ug/kg) }\end{array}$ & $\begin{array}{l}\text { RSD } \\
(\%)\end{array}$ & $\begin{array}{l}\text { No. of replicates } \\
\text { for extraction }\end{array}$ \\
\hline \multirow[t]{5}{*}{48} & F1 & 8 & 43 & 3 \\
\hline & $\mathrm{F} 2$ & 8 & 43 & 3 \\
\hline & F3 & $<2$ & 0 & 1 \\
\hline & $\mathrm{F} 4$ & $<2$ & 0 & 3 \\
\hline & F5 & 136 & 7 & 3 \\
\hline \multirow[t]{5}{*}{15} & F1 & $<2$ & 0 & 3 \\
\hline & $\mathrm{F} 2$ & 12 & 0 & 3 \\
\hline & F3 & $<2$ & 0 & 1 \\
\hline & $\mathrm{F} 4$ & 96 & 11 & 3 \\
\hline & F5 & 18 & 0 & 3 \\
\hline \multirow[t]{5}{*}{16} & F1 & $<2$ & 0 & 2 \\
\hline & $\mathrm{F} 2$ & 24 & 0 & 2 \\
\hline & F3 & $<2$ & 0 & 0 \\
\hline & $\mathrm{F} 4$ & 108 & 0 & 2 \\
\hline & F5 & 39 & 11 & 2 \\
\hline \multirow[t]{5}{*}{50} & F1 & 212 & 7 & 3 \\
\hline & $\mathrm{F} 2$ & 16 & 22 & 3 \\
\hline & F3 & $<2$ & 0 & 1 \\
\hline & $\mathrm{F} 4$ & 619 & 6 & 3 \\
\hline & F5 & 230 & 9 & 3 \\
\hline \multirow[t]{5}{*}{55} & F1 & 6 & 0 & 2 \\
\hline & $\mathrm{F} 2$ & $<2$ & 0 & 2 \\
\hline & F3 & $<2$ & 0 & 0 \\
\hline & $\mathrm{F} 4$ & 36 & 23 & 2 \\
\hline & F5 & 12 & 0 & 2 \\
\hline \multirow[t]{5}{*}{63} & F1 & 84 & 10 & 2 \\
\hline & F2 & 27 & 16 & 2 \\
\hline & F3 & 114 & 7 & 0 \\
\hline & F4 & 1588 & 3 & 2 \\
\hline & F5 & 557 & 3 & 2 \\
\hline \multirow[t]{5}{*}{72} & F1 & 38 & 24 & 3 \\
\hline & $\mathrm{F} 2$ & 44 & 21 & 3 \\
\hline & F3 & $<2$ & 0 & 1 \\
\hline & $\mathrm{F} 4$ & 130 & 13 & 3 \\
\hline & F5 & 64 & 5 & 3 \\
\hline \multirow[t]{5}{*}{74} & F1 & 87 & 15 & 2 \\
\hline & $\mathrm{F} 2$ & 72 & 0 & 2 \\
\hline & $\mathrm{F} 3$ & $<2$ & 0 & 0 \\
\hline & $\mathrm{F} 4$ & 12 & 0 & 2 \\
\hline & F5 & 42 & 40 & 2 \\
\hline
\end{tabular}


Appendix 1 Table A-3: Mean values and relative standard deviation of replicate samples in sequential extraction

\begin{tabular}{|c|c|c|c|c|}
\hline Sample ID & Fraction & $\begin{array}{c}\text { Mean } \\
\text { (ug/kg) }\end{array}$ & $\begin{array}{l}\text { RSD } \\
(\%)\end{array}$ & $\begin{array}{c}\text { No. of replicates } \\
\text { for extraction }\end{array}$ \\
\hline \multirow[t]{5}{*}{59} & $\mathrm{~F} 1$ & $<2$ & 0 & 2 \\
\hline & $\mathrm{F} 2$ & 21 & 20 & 2 \\
\hline & F3 & $<2$ & 0 & 0 \\
\hline & $\mathrm{F} 4$ & 48 & 0 & 2 \\
\hline & $\mathrm{F} 5$ & 30 & 28 & 2 \\
\hline \multirow[t]{5}{*}{36} & F1 & $<2$ & 0 & 3 \\
\hline & $\mathrm{F} 2$ & $<2$ & 0 & 3 \\
\hline & F3 & $<2$ & 0 & 2 \\
\hline & $\mathrm{F} 4$ & $<2$ & 0 & 3 \\
\hline & F5 & 46 & 37 & 3 \\
\hline \multirow[t]{5}{*}{53} & $\mathrm{~F} 1$ & $<2$ & 0 & 3 \\
\hline & $\mathrm{F} 2$ & $<2$ & 0 & 3 \\
\hline & F3 & $<2$ & 0 & 0 \\
\hline & $\mathrm{F} 4$ & 14 & 25 & 3 \\
\hline & $\mathrm{F} 5$ & 6 & 0 & 3 \\
\hline \multirow[t]{5}{*}{2} & F1 & $<2$ & 0 & 3 \\
\hline & $\mathrm{F} 2$ & 30 & 0 & 3 \\
\hline & F3 & $<2$ & 0 & 0 \\
\hline & $\mathrm{F} 4$ & $<2$ & 0 & 3 \\
\hline & $\mathrm{F} 5$ & $<2$ & 0 & 3 \\
\hline \multirow[t]{5}{*}{8} & $\mathrm{~F} 1$ & $<2$ & 0 & 2 \\
\hline & $\mathrm{F} 2$ & 27 & 47 & 2 \\
\hline & F3 & 0 & 0 & 0 \\
\hline & $\mathrm{F} 4$ & 24 & 35 & 2 \\
\hline & F5 & $<2$ & 0 & 2 \\
\hline \multirow[t]{5}{*}{3} & $\mathrm{~F} 1$ & $<2$ & 0 & 2 \\
\hline & $\mathrm{F} 2$ & 38 & 33 & 2 \\
\hline & F3 & 0 & 0 & 0 \\
\hline & $\mathrm{F} 4$ & 24 & 25 & 2 \\
\hline & $\mathrm{F} 5$ & $<2$ & 0 & 2 \\
\hline \multirow[t]{5}{*}{1} & F1 & $<2$ & 0 & 2 \\
\hline & $\mathrm{F} 2$ & 21 & 20 & 2 \\
\hline & F3 & $<2$ & 0 & 1 \\
\hline & $\mathrm{F} 4$ & 66 & 39 & 2 \\
\hline & F5 & 0 & 0 & 22 \\
\hline \multirow[t]{4}{*}{9} & $\mathrm{~F} 1$ & $<2$ & 0 & 2 \\
\hline & $\mathrm{F} 2$ & 18 & 0 & 0 \\
\hline & F3 & $<2$ & 0 & 2 \\
\hline & $\mathrm{F} 4$ & 15 & 28 & 2 \\
\hline
\end{tabular}


Appendix 1 Table A-4: Sequential extraction data for each individual fraction

(Page 1 of 2)

\begin{tabular}{|c|c|c|c|c|c|c|c|c|c|c|}
\hline $\begin{array}{c}\text { Sample } \\
\text { ID }\end{array}$ & Rock type & $\begin{array}{c}\text { Depth } \\
\text { (ft) }\end{array}$ & $\begin{array}{c}\text { Thickness } \\
\text { (ft) }\end{array}$ & $\begin{array}{c}\text { Total } \\
\text { Bulk } \\
\text { Se } \\
\text { (mg/kg) }\end{array}$ & $\begin{array}{c}\text { Residual } \\
\text { (ug/kg) }\end{array}$ & $\begin{array}{c}F 5^{* *} \\
\text { (ug/kg) }\end{array}$ & $\begin{array}{c}F 4^{\star *} \\
(u g / k g)\end{array}$ & $\begin{array}{c}F 3^{* *} \\
\text { (ug/kg) }\end{array}$ & $\begin{array}{c}F 2^{\star *} \\
(\mathrm{ug} / \mathrm{kg})\end{array}$ & $\begin{array}{c}F 1^{* *} \\
(\mathrm{ug} / \mathrm{kg})\end{array}$ \\
\hline 12 & Sandstone & 80.1 & 5.15 & $<0.20$ & $<2$ & $<2$ & $<2$ & $<2$ & $<2$ & $<2$ \\
\hline 14 & Sandstone & 83.5 & 3 & $<0.20$ & $<2$ & $<2$ & $<2$ & $<2$ & $<2$ & $<2$ \\
\hline 15 & Shale & 86.5 & 3 & 0.3 & 157 & 18 & 96 & $<2$ & 12 & $<2$ \\
\hline 16 & Shale & 88.5 & 2.05 & 0.42 & 200 & 38.9 & 108 & $<2$ & 24 & $<2$ \\
\hline $16 \mathrm{~A}$ & Coal & 89.2 & 0.65 & $<0.20$ & $<2$ & $<2$ & $<2$ & $<2$ & $<2$ & $<2$ \\
\hline 17 & Mudstone & 91.7 & 2.5 & 0.2 & 110 & 26 & 44 & $<2$ & $<2$ & $<2$ \\
\hline 27 & Mudstone/Sandstone & 130 & 3 & 0.24 & 200 & $<2$ & $<2$ & $<2$ & $<2$ & $<2$ \\
\hline 28 & Mudstone & 133 & 3 & 0.28 & 200 & $<2$ & 20 & $<2$ & 12 & $<2$ \\
\hline 33 & Sandstone & 151 & 1.55 & 0.28 & 200 & $<2$ & $<2$ & $<2$ & $<2$ & $<2$ \\
\hline 34 & Shale & 154 & 3 & 0.4 & 153 & 44 & 106 & $<2$ & 37.9 & 16 \\
\hline 35 & Shale & 157 & 3.45 & 0.52 & 400 & $<2$ & 219 & $<2$ & 30 & 21 \\
\hline 36 & Sandstone & 158 & 0.35 & 0.94 & 743 & 45.9 & $<2$ & $<2$ & $<2$ & $<2$ \\
\hline 37 & Sandstone/Carbolith & 158 & 0.5 & 1.26 & 1000 & $<2$ & $<2$ & $<2$ & 12 & $<2$ \\
\hline $37 \mathrm{~A}$ & Coal & 159 & 1 & 3.72 & 2265 & 219 & 72 & 21 & 42 & 450 \\
\hline $37 \mathrm{~B}$ & Coal & 161 & 2.05 & 0.42 & 290 & 41.9 & 63 & $<2$ & 26.9 & 21 \\
\hline $38 \mathrm{~A}$ & Mudstone & 163 & 2.1 & 0.32 & 200 & $<2$ & 54 & $<2$ & 47.9 & $<2$ \\
\hline $39 A$ & Carbolith & 165 & 1.6 & 0.54 & 487 & 41.9 & $<0.20$ & $<2$ & $<2$ & $<2$ \\
\hline $40 \mathrm{~A}$ & Sandstone & 169 & 4.4 & $<0.20$ & $<2$ & $<2$ & $<2$ & $<2$ & $<2$ & $<2$ \\
\hline 48 & Shale & 201 & 2.1 & 0.3 & 137 & 136 & $<2$ & $<2$ & 8 & 8 \\
\hline 49 & Carbolith & 202 & 1.2 & 3.38 & 2140 & 627 & 12 & 18 & 53.9 & 17 \\
\hline 50 & Coal & 202 & 0.45 & 2.58 & 1517 & 230 & 619 & $<2$ & 16 & 212 \\
\hline $50 A$ & Coal & 203 & 1 & 1.16 & 955 & 201 & 0 & $<2$ & 81 & 14 \\
\hline 51 & Shale & 204 & 0.1 & 1.16 & 645 & 47.9 & 162 & $<2$ & 87 & 36 \\
\hline 52 & Mudstone & 206 & 3 & 0.36 & 300 & 35.9 & 14 & $<2$ & $<2$ & $<2$ \\
\hline 53 & Sandstone & 208 & 1.45 & 0.28 & 250 & 6 & 14 & $<2$ & $<2$ & $<2$ \\
\hline 54 & Coal & 208 & 0.2 & 1 & 505 & 144 & 144 & $<2$ & $<2$ & $<2$ \\
\hline
\end{tabular}

Notes: ${ }^{* *}$ : Se concentration by fraction from the sequential extraction procedure. 
Appendix 1 Table A-4: Sequential extraction data for each individual fraction

(Page 2 of 2)

\begin{tabular}{|c|c|c|c|c|c|c|c|c|c|c|}
\hline $\begin{array}{c}\text { Sample } \\
\text { ID }\end{array}$ & Rock type & $\begin{array}{c}\text { Depth } \\
\text { (ft) }\end{array}$ & $\begin{array}{c}\text { Thickness } \\
\text { (ft) }\end{array}$ & $\begin{array}{c}\text { Total } \\
\text { Se } \\
\text { (mg/kg) }\end{array}$ & $\begin{array}{c}\text { Residual } \\
\text { (ug/kg) }\end{array}$ & $\begin{array}{c}\text { F5** } \\
\text { (ug/kg) }\end{array}$ & $\begin{array}{c}\text { F4** } \\
\text { (ug/kg) }\end{array}$ & $\begin{array}{c}\text { F3** } \\
\text { (ug/kg) }\end{array}$ & $\begin{array}{c}\text { F2** } \\
\text { (ug/kg) }\end{array}$ & $\begin{array}{c}\text { F1** } \\
\text { (ug/kg) }\end{array}$ \\
\hline 55 & Shale & 211 & 3 & 0.26 & 200 & 12 & 36 & $<2$ & $<2$ & 6 \\
\hline 56 & Shale & 213 & 2.25 & 0.78 & 435 & 105 & 126 & $<2$ & 57 & 39 \\
\hline 57 & Carbolith & 214 & 0.31 & 7.12 & 6317 & 178 & 280 & 26 & 16 & 16 \\
\hline $57 \mathrm{~A}$ & Coal & 214 & 0.89 & 0.5 & 210 & 16.9 & $<2$ & $<2$ & 14.5 & 16 \\
\hline 61 & Shale & 226 & 2.4 & 1.06 & 367 & 170 & 116 & 8 & $<2$ & 19 \\
\hline 62 & Carbolith & 226 & 0.15 & 9.44 & 6167 & 617 & 126 & 102 & 28 & 75 \\
\hline $62 A$ & Coal & 227 & 1.1 & 5.96 & 4750 & 359 & 105 & 123 & 30 & 92.9 \\
\hline 63 & Shale & 228 & 0.63 & 5.36 & 1500 & 557 & 1588 & 108 & 27 & 83.9 \\
\hline $63 A$ & Shale & 230 & 1.77 & 1.98 & 1035 & 344 & 135 & $<2$ & 59.9 & 71.9 \\
\hline 70 & Shale & 250 & 3 & 0.24 & 100 & 22 & 18 & $<2$ & 20 & 0 \\
\hline 72 & Shale & 253 & 1 & 0.64 & 300 & 70 & 130 & $<2$ & 44 & 38 \\
\hline 73 & Coal & 254 & 0.3 & 1.18 & 1000 & 22 & 40 & $<2$ & 21 & 42 \\
\hline $73 \mathrm{~A}$ & Coal & 256 & 2.53 & $<0.20$ & $<2$ & $<2$ & $<2$ & $<2$ & $<2$ & $<2$ \\
\hline $73 B$ & Coal & 257 & 0.92 & 2.02 & 2000 & 80 & 78 & $<2$ & $<2$ & 51 \\
\hline 74 & Shale & 257 & 0.1 & 1 & 725 & 42 & 12 & $<2$ & 72 & 87 \\
\hline 75 & Shale & 261 & 3.4 & 0.34 & 275 & 15 & 48 & $<2$ & 12 & 18 \\
\hline 76 & Shale & 263 & 2.2 & 0.76 & 450 & 32 & 72 & $<2$ & 68 & 28 \\
\hline $76 \mathrm{~A}$ & Coal & 264 & 1.95 & 2.06 & 1625 & 174 & 168 & $<2$ & 69 & 24 \\
\hline 77 & Mudstone & 265 & 0.55 & 2.08 & 100 & 122 & 202 & $<2$ & 40 & 32 \\
\hline 78 & Mudstone & 267 & 1.35 & 0.3 & 250 & 45.9 & 36 & $<2$ & 65.9 & 18 \\
\hline
\end{tabular}

Notes: **: Se concentration by fraction from the sequential extraction procedure 
Appendix 1 Table A-5: Comparison of arithmetic mean and geometric mean for the data

\begin{tabular}{|c|c|c|c|}
\hline Sample ID & Arithmetic Mean & Geometric Mean & $\%$ Diff \\
\hline 34 & 55.9 & 55.8 & 0.2 \\
\hline 36 & 4.7 & 4.5 & 3.8 \\
\hline 35 & 51.7 & 50.4 & 2.5 \\
\hline 37 & 0.9 & 0.9 & 0 \\
\hline 38 & 31.8 & 31.7 & 0.3 \\
\hline 39 & 7.7 & 7.3 & 5.2 \\
\hline 48 & 50.6 & 50.5 & 0.2 \\
\hline 49 & 31.9 & 31.9 & 0 \\
\hline $37 A$ & 16.5 & 16.3 & 1.2 \\
\hline $37 \mathrm{~B}$ & 36.3 & 36.3 & 0 \\
\hline 28 & 11.4 & 11.2 & 1.7 \\
\hline 27 & 2.5 & 2.5 & 0 \\
\hline 15 & 42.9 & 42.8 & 0.2 \\
\hline 16 & 40.6 & 40.6 & 0 \\
\hline $50 \mathrm{~A}$ & 36.7 & 36.7 & 0 \\
\hline 50 & 41.7 & 41.7 & 0 \\
\hline $57 \mathrm{~A}$ & 53.5 & 53.4 & 0.2 \\
\hline 57 & 9.7 & 9.7 & 0 \\
\hline 52 & 13.8 & 13.7 & 0.7 \\
\hline 54 & 28.7 & 28.7 & 0 \\
\hline 53 & 7.1 & 7.1 & 0 \\
\hline 55 & 20.7 & 20.6 & 0.5 \\
\hline 62 & 14.3 & 14.2 & 0.7 \\
\hline $62 \mathrm{~A}$ & 11.9 & 11.9 & 0 \\
\hline 61 & 33.4 & 33.3 & 0.3 \\
\hline 63 & 44.1 & 44.1 & 0 \\
\hline 73 & 8.8 & 8.8 & 0 \\
\hline 72 & 43.1 & 43.0 & 0.2 \\
\hline $73 B$ & 10.2 & 10.2 & 0 \\
\hline 77 & 19.0 & 19.0 & 0 \\
\hline $76 \mathrm{~A}$ & 21.1 & 21.1 & 0 \\
\hline 76 & 26.5 & 26.5 & 0 \\
\hline 74 & 21.2 & 21.2 & 0 \\
\hline 75 & 27.3 & 27.3 & 0 \\
\hline 51 & 26.6 & 26.6 & 0 \\
\hline 17 & 34.9 & 34.9 & 0 \\
\hline 78 & 55.2 & 55.2 & 0 \\
\hline 56 & 41.8 & 41.8 & 0 \\
\hline $63 \mathrm{~A}$ & 30.8 & 30.8 & 0 \\
\hline 70 & 22.4 & 22.3 & 0.4 \\
\hline
\end{tabular}


Mimi Roy
e-mail: mroy@geo.wvu.edu; mimi_roy2003@yahoo.com

Home address

1325 Winona Ave.

Apt\#3

Morgantown WV-26505

Cell: (304) 3190774

\section{Office address}

West Virginia University

Dept. of Geology

422, White Hall

Morgantown, WV-26506

\section{Objective}

My research interests revolve around coal geochemistry and contaminant chemistry including their fate and transport, chemically and microbiologically reactive transport in groundwater and soils, hydrogeology and other environmental issues.

\section{$\underline{\text { Education }}$}

Master of Science (MS)

May 2003 -Dec 2005

Major: Geology

West Virginia University

Research Title: A Detailed Sequential Extraction Study of Selenium in Coal and Coal-Associated Strata from a Coal Mine in West Virginia.

Advisor: Dr. Dorothy Vesper

Master of Science (MS)

Major: Geology

Presidency College (India)

Research Title: A Study of the Structural Evolution and Metamorphic Changes in the Singbhum Shear Zone at Bangriposi, Orissa

Advisor: Dr. Harendra Nath Bhattacharya.

Bachelor of Science (BS)

1997

University of Calcutta (India)

Major: Geology

Minor: Chemistry, Mathematics 


\section{Professional Experience}

\section{Research Assistant}

May 2004 - Dec 2005

West Virginia Water Research Institute

National Research Center for Coal and Energy

West Virginia University

Project Name: OSM 178d Selenium

- Sequential Extraction of Se from water and rock samples

\section{Teaching Assistant}

August 2003 - April 2004

West Virginia University

Department of Geology

\section{Research Assistant}

May 2003 - July 2003

West Virginia Hydrology Research Center

National Research Center for Coal and Energy

West Virginia University

Project Name: Monongahela Basin Mine Pool Project

- GIS mapping of active and flooded mines

- Looking at coal mine chemistry

Teaching Assistant

August 2002 - April 2003

University of Texas at Arlington

Department of Geosciences

\section{Awards and Honors}

Sigma Xi Research Poster Competition - Basic Sciences: First

April 2005

Sigma Xi Research Poster Competition - Overall: First

April 2005

Graduate Scholarship: The University of Texas at Arlington

August 2002 - April 2003

National Merit Scholarship: Govt. of West Bengal, India

1992 


\section{Presentations}

(Mimi Roy first author and presenter)

West Virginia Academy of Sciences Meeting (2005) A sequential extraction study of Selenium in coal and coal associated strata from rock cores in West Virginia (Poster)

\section{Professional Affiliation}

Sigma Xi, The Scientific Research Society

\section{Computer Skills}

Operating System: UNIX, WINDOWS

Languages: C, C++, Visual Basic, Oracle

GIS Tools: ArcView 3.x, ArcGIS (ArcMap, Spatial Analyst, 3D Analyst)

Groundwater Modeling Tools: MODFLOW, Groundwater Vistas, Surfer v.7.0

Geochemical Modeling Tools: Visual MINTEQA2

Remote Sensing Tools: Erdas Imagine (8.6) 